THIAGO OLITTA BASSO

\title{
MELHORAMENTO DA FERMENTAÇÃO ALCOÓLICA EM \\ Saccharomyces cerevisiae \\ POR ENGENHARIA EVOLUTIVA
}

Tese apresentada ao Programa de PósGraduação Interunidades em Biotecnologia USP / Instituto Butantan / IPT, para obtenção do Título de Doutor em Biotecnologia. 
THIAGO OLITTA BASSO

\section{MELHORAMENTO DA FERMENTAÇÃO ALCOÓLICA EM}

Saccharomyces cerevisiae

POR ENGENHARIA EVOLUTIVA

Tese apresentada ao Programade PósGraduação Interunidades em Biotecnologia USP / Instituto Butantan / IPT, para obtenção do Título de Doutor em Biotecnologia.

Área de concentração: Biotecnologia

Orientador:

Andreas Karoly Gombert

Co-orientador:

Aldo Tonso

São Paulo

2011 
DADOS DE CATALOGAÇÃO NA PUBLICAÇÃO (CIP)

Serviço de Biblioteca e Informação Biomédica do

Instituto de Ciências Biomédicas da Universidade de São Paulo

(c) reprodução total

\section{Basso, Thiago Olitta.}

Melhoramento da fermentação alcóolica em Saccharomyces cerevisiae por engenharia evolutiva / Thiago Olitta Basso. -- São Paulo, 2011.

Orientador: Andreas Karoly Gombert.

Tese (Doutorado) - Universidade de São Paulo. Instituto de Ciências Biomédicas. Programa de Pós-Graduação Interunidades em Biotecnologia USP/IPT/Instituto Butantan. Área de concentração:

Biotecnologia. Linha de pesquisa: Fisiologia e engenharia metabólica de leveduras.

Versão do título para o inglês: Improvement of alcoholic fermentation in Saccharomyces cerevisiae by evolutionary engineering.

Descritores: 1. Sacarose 2. Saccharomyces cerevisiae 3. Invertase $\begin{array}{lll}\text { 4. Engenharia evolutiva 5. Etanol } & \text { 6. AGT1 I. Gombert, Andreas }\end{array}$ Karoly II. Universidade de São Paulo. Instituto de Ciências Biomédicas. Programa de Pós-Graduação Interunidades em Biotecnologia USP/IPT/Instituto Butantan III. Título. 


\section{UNIVERSIDADE DE SÃO PAULO \\ Programa de Pós-Graduação Interunidades em Biotecnologia \\ Universidade de São Paulo, Instituto Butantan, Instituto de Pesquisas Tecnológicas}

Candidato(a): $\quad$ Thiago Olitta Basso.

Título da Tese: $\quad$ Melhoramento da fermentação alcóolica em Saccharomyces cerevisiae por engenharia evolutiva.

Orientador(a): $\quad$ Andreas Karoly Gombert.

A Comissão Julgadora dos trabalhos de Defesa da Tese de Doutorado, em sessão pública realizada a considerou

\section{( ) Aprovado(a) ( ) Reprovado(a)}

Examinador(a): Assinatura:

Nome:

Instituição:

Examinador(a): Assinatura:

Nome:

Instituição:

Examinador(a): Assinatura:

Nome:

Instituição:

Examinador(a): Assinatura:

Nome:

Instituição:

Presidente: Assinatura:

Nome:

Instituição: 
Ao meu amor Luisa, por ser quem é...

te amo!

Aos meus pais e irmãos pelo carinho, exemplo e apoio durante toda a minha vida!

Sem vocês simplesmente não seria! 


\section{AGRADECIMENTOS}

Ao meu orientador Prof. Andreas Karoly Gombert pela sábia orientação e oportunidades concedidas. Espero muito por transmitir todos os ensinamentos que aprendi com ele durante estes quatro anos;

Ao meu co-orientador Prof. Aldo Tonso pela dedição constante em desenvolver e aprimorar o sistema de cultivos contínuos do LEB (parte fundamental deste doutoramento), pela amizade e também pelos passeios inusitados no comércio da Santa Ifigênia e arredores;

Ao Prof. Boris Stambuk por compartilhar uma das suas linhas de pesquisa, pelas sugestões ao longo do trabalho e por dividir comigo sua vasta experiência sobre o metabolismo de leveduras;

Ao amigo Marcelo Dário, companheiro de labuta nos "itermináveis" cultivos contínuos, pelo apoio e dedicação em inúmeras etapas experimentais deste projeto de doutoramento;

Aos Prof. Jack Pronk, Prof. Ton van Maris, Prof. Jean-Marc Daran e ao doutorando Ir. Stefan de Kok pela profunda dedicação ao projeto e excelente clima de trabalho proporcionado durante o ano passado em Delft no Industrial Microbiology Group (Delft University of Technology);

Às pessoas que participaram desta trajetória, seja no Brasil ou na Holanda, ensinando-me muito sobre ciência e convivência ao longo de todo o caminho! Os nomes de cada um de vocês sempre passam pela minha mente e acredito que ao colocá-los neste texto em ordem alfabética, como é de costume, deixaria nossa relação deveras "protocolar". Esta nunca foi nem nunca será a minha intenção e gostaria de registrar os meus sinceros agradecimentos à cada um de vocês! Muitíssimo obrigado!

Ao Laboratório de Engenharia Bioquímica do Departamento de Engenharia Química da Escola Politécnica da Universidade de São Paulo; 
Ao Laboratório de Tecnologia de Leveduras do Departamento de Ciências Biológicas da Escola Superior de Agricultura de Luiz de Queiroz da Universidade de São Paulo;

À CAPES pela concessão da bolsa de doutoramento e da bolsa de estágio-sanduíche, modalidade PDEE, processo 2388-0/09;

Ao CNPq pelo auxílio concedido na modalidade Edital Universal, projeto "Engenharia Evolutiva de Leveduras", Edital MCT/CNPq/02/2006, processo 484785/2006-0;

À FAPESP pelo auxílio concedido na modalidade "Auxílios Regulares", dentro do Programa BIOEN, projeto “Engenharia Evolutiva de Leveduras”, processo 2007/59776-7. 
"To alcohol: the cause of... and solution to... all of life's problems."

Homer J. Simpson 


\section{RESUMO}

Basso TO. Melhoramento da fermentação alcoólica em Saccharomyces cerevisiae por engenharia evolutiva. [Tese (Doutorado em Biotecnologia)]. São Paulo: Instituo de Ciências Biomédicas da Universidade de São Paulo; 2011.

Durante o crescimento da levedura Saccharomyces cerevisiae em meios contendo sacarose, a enzima invertase hidrolisa a sacarose no ambiente extracelular em glicose e frutose, as quais são posteriormente captadas pelas células por difusão facilitada. Num trabalho prévio, a localização da enzima invertase foi modificada nesta levedura, eliminando-se a forma extracelular e superexpressando-se a forma intracelular da enzima (Stambuk et al., 2009). Como resultado, a captação de sacarose por esta linhagem modificada (iSUC2) é realizada pelo co-transporte ativo com íons $\mathrm{H}^{+}$, implicando no gasto de 1 mol de ATP para cada mol de $\mathrm{H}^{+}$extrudado pelas células para manutenção do $\mathrm{pH}$ intracelular. Como forma de compensar este gasto energético, espera-se que a linhagem iSUC2 desvie uma maior parte do fluxo de carbono para a geração de energia e, consequentemente, para a formação de etanol, em relação a uma linhagem selvagem. No presente trabalho, uma avaliação fisiológica quantitativa de uma linhagem com esta modificação genética foi realizada tanto em quimiostatos limitados por sacarose, como em cultivos descontínuos com sacarose como única fonte de carbono. Os dados obtidos em quimiostatos anaeróbios demonstram que na linhagem iSUC2 a enzima invertase ficou retida no ambiente intracelular e apresentou atividade absoluta total cerca de duas vezes maior que na linhagem-referência (SUC2). Além disto, verificou-se um aumento de $4 \%$ no fator de conversão de sacarose a etanol $\left(\mathrm{Y}_{\mathrm{ETH} / \mathrm{S}}\right)$, em relação à linhagem SUC2. No entanto, como foi observado que cerca de $8 \%$ da sacarose não foi consumida pelas células da linhagem iSUC2 durante o estado-estacionário dos quimiostatos anaeróbios, decidiu-se melhorar a capacidade do transporte ativo deste dissacarídeo nesta linhagem através de uma estratégia de engenharia evolutiva caracterizada pelo cultivo destas células em quimiostatos longos limitados por sacarose, em anaerobiose. Obteve-se assim, após cerca de 60 gerações, uma linhagem mutante (iSUC2 evoluída) com atividade de transporte de sacarose 20 vezes superior à linhagem iSUC2, sendo capaz de consumir toda a sacarose do meio de cultivo. Esta linhagem apresentou um aumento de $11 \%$ no $Y_{\mathrm{ETH} / \mathrm{S}}$ e uma diminuição de $27 \%$ no fator de conversão de sacarose a células $\left(Y_{X / S}\right)$, quando comparada à linhagem-referência. $A$ análise do transcriptoma revelou 
o aumento da expressão de vários genes codificadores de transportadores de hexoses, bem como genes relacionados ao metabolismo de maltose, incluindo o gene do transportador de alta-afinidade para alfa-glicosídeos $A G T 1$, quando a linhagem iSUC2 evoluída foi comparada à linhagem iSUC2. Detectou-se que a evolução em quimiostato resultou na duplicação do gene $A G T 1$, sem que houvesse mutação neste gene. Através da superexpressão do gene AGT1 na linhagem iSUC2, conseguiu-se gerar uma linhagem que apresentou $\mathrm{Y}_{\mathrm{ETH} / \mathrm{s}}$ muito próximo ao da linhagem iSUC2 evoluída. No entanto, outros parâmetros fisiológicos, foram diferentes nestas duas linhagens, indicando que a duplicação do gene $A G T 1$ não foi a única mutação que ocorreu durante o processo de evolução em quimiostato. Este trabalho ilustra o potencial da combinação entre engenharia metabólica e engenharia evolutiva para a obtenção de linhagens de levedura melhoradas, para aplicação na produção industrial de etanol combustível a partir de meios contendo sacarose.

Palavras-chave: Sacarose. Saccharomyces cerevisiae. Invertase. Engenharia evolutiva. Etanol. AGT1. 


\begin{abstract}
Basso TO. Improvement of alcoholic fermentation in Saccharomyces cerevisiae by evolutionary engineering. [Ph.D. Thesis (Biotechnology)]. São Paulo: Instituo de Ciências Biomédicas da Universidade de São Paulo; 2011.
\end{abstract}

When growing on sucrose-containing substrates, Saccharomyces cerevisiae secretes invertase that hydrolyses sucrose into glucose and fructose, which are subsequently assimilated by facilitated diffusion. In a previous work, the cellular location of invertase in yeast was modified, by eliminating the extracellular form of the enzyme and over-expressing the intracellular one (Stambuk et al., 2009). As a result, sucrose uptake by this modified strain (iSUC2) occurs by an active $\mathrm{H}^{+}$-sucrose symport system, in which 1 ATP needs to be used by the cells to extrude the proton co-transported. In order to compensate for this, it is expected that these cells will deviate a higher proportion of the carbon flow towards energy generation, and consequently to ethanol formation, in comparison with the wild-type phenotype (SUC2). In the present work, a quantitative physiological evaluation of the iSUC2 strain was performed in both batch and chemostat cultures. Cells from the iSUC2 strain harvested from steady-state anaerobic sucrose-limited chemostats retained all invertase intracellularly and showed a 2-fold higher total invertase activity, when compared to the SUC2 strain grown under identical conditions. Besides this, the ethanol yield on sucrose in the former cells was $4 \%$ higher than in the latter case. However, due to the high levels of residual sucrose during these cultivations with the iSUC2 strain, we attempted to improve the transport capacity in the iSUC2 strain by evolutionary engineering. After 60 generations of cultivation in an anaerobic sucrose-limited chemostat, an evolved strain was selected, which presented a 20-fold increase in the sucrose transport capacity, when compared with the parental strain (iSUC2), leading to almost no residual sucrose. During growth of this evolved strain in anaerobic sucrose-limited chemostats, the ethanol yield on sucrose was $11 \%$ higher and the biomass yield on sucrose was $27 \%$ lower, when compared with the SUC2 strain. Transcriptome analysis revealed an increase in the expression level of several hexose transporters, as well as many MAL-related genes, including the gene for the high-affinity permease $A G T 1$. Indeed, it was verified that this gene was duplicated during the evolution experiment, but no point mutation was detected. By over-expressing the AGT1 gene in the iSUC2 strain, it was possible to attain a similar ethanol yield on sucrose, when compared to 
the evolved iSUC2 strain. However, several other physiological parameters were different in both strains, indicating that the AGT1 gene duplication was not the only mutation that occurred during evolution in the chemostat. To conclude, this work illustrates that the combination of metabolic and evolutionary engineering is a powerful strategy to obtain improved sucrose-fermenting yeast strains.

Keywords: Sucrose. Saccharomyces cerevisiae. Invertase. Evolutionary engineering. Ethanol. AGT1. 


\section{LISTA DE SÍMBOLOS}

\begin{tabular}{|c|c|}
\hline $\mathrm{Abs}_{600}$ & absorbância a 600 nm \\
\hline$D$ & vazão específica de alimentação $\left(\mathrm{h}^{-1}\right)$ \\
\hline DW & massa seca de células ("dry weight") \\
\hline ETH & etanol \\
\hline FC & capacidade fermentativa [mmol ETH.(g DW.h $)^{-1}$ ] \\
\hline g GLC eq & $\begin{array}{l}\text { gramas de glicose (hexose) equivalentes; onde } 1 \mathrm{~g} \text { de sacarose é igual a } \\
1,053 \mathrm{~g} \text { de glicose (hexose) equivalente }\end{array}$ \\
\hline GLC & glicose \\
\hline GLYC & glicerol \\
\hline$K_{\mathrm{m}}$ & constante de Michaellis-Menten ou constante de saturação pelo substrato \\
\hline \multirow[t]{2}{*}{ mmol GLC eq } & mmol de glicose (hexose) equivalentes; onde $1 \mathrm{mmol}$ de sacarose é igual a \\
\hline & $2 \mathrm{mmol}$ de glicose (hexose) equivalentes \\
\hline LAC & lactato \\
\hline PYR & piruvato \\
\hline$q_{A C E}$ & velocidade específica de produção de acetato [mmol ETH.(g DW.h $\left.)^{-1}\right]$ \\
\hline qCO2 & velocidade específica de produção de $\left.\mathrm{CO}_{2}[\mathrm{mmol} \text { ETH.(g DW.h })^{-1}\right]$ \\
\hline $\mathrm{q}_{\mathrm{ETH}}$ & velocidade específica de produção de etanol[mmol ETH.(g DW.h $\left.)^{-1}\right]$ \\
\hline $\mathrm{q}_{\mathrm{GLYC}}$ & velocidade específica de produção de glicerol[mmol GLYC.(g DW.h $\left.)^{-1}\right]$ \\
\hline$q_{\text {LAC }}$ & velocidade específica de produção de lactato[mmol LAC.(g DW.h $\left.)^{-1}\right]$ \\
\hline q02 & velocidade específica de consumo de oxigênio[mmol O2.(g DW.h $\left.)^{-1}\right]$ \\
\hline $\mathrm{q}_{\mathrm{PYR}}$ & velocidade específica de produção de piruvato[mmol PYR.(g DW.h $)^{-1}$ ] \\
\hline qs & velocidade específica de consumo de substrato [mmol.(g DW.h $\left.)^{-1}\right]$ \\
\hline qsucc & velocidade específica de produção de succinato [mmol SUCC.(g DW.h $)^{-1}$ ] \\
\hline SUC & sacarose \\
\hline SUCC & succinato \\
\hline$V_{\max }$ & velocidade específica máxima de transporte de sacarose [nmol.(mg \\
\hline \multicolumn{2}{|l|}{ DW.min $\left.)^{-1}\right]$} \\
\hline$V_{\text {transporte }}$ & velocidade específica de transporte de sacarose [nmol.(mg DW.min $)^{-1}$ ] \\
\hline $\mathrm{Y}_{\mathrm{ETH} / \mathrm{S}}$ & fator de conversão de substrato em etanol (g ETH.g substrato ${ }^{-1}$ ) \\
\hline$Y_{X / S}$ & fator de conversão de substrato a biomassa (g DW.g substrato ${ }^{-1}$ ) \\
\hline
\end{tabular}


velocidade específica máxima de crescimento $\left(\mathrm{h}^{-1}\right)$ 


\section{LISTA DE ABREVIATURAS}

CAMP

LEB/USP

LMI/TU Delft

SGD

$P_{A D H 1}$

$\mathrm{pb}$

$P_{T D H 3}$

$P_{T P 11}$
Adenosina monofostato cíclico

Laboratório de Engenharia Bioquímica da Universidade de São Paulo

Laboratório de Microbiologia Industrial da Delft University of Technology Saccharomyces Genome Database

Promotor do gene ADH1 (Álcool desidrogenase)

pares de bases

Promotor do gene TDH3(Triose Fosfato Desidrogenase)

Promotor do gene TPI1 (Triose Fosfato Isomerase) 


\section{LISTA DE FIGURAS}

Figura 1.1 - Esquema resumido das duas vias (extra- e intracelular, mediadas pelas enzimas invertase extracelular e invertase intracelular, respectivamente) para o metabolismo da

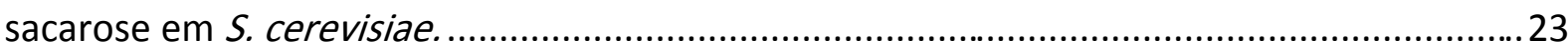

Figura 2.1 - Esquema da estrutura genética do gene SUC2 em S. cerevisiae.........................31

Figura 2.2 - Esquema geral da estrutura genética dos loci MAL em S. cerevisiae. .................33

Figura 4.1 - Configuração geral do sistema de biorreatores para cultivos contínuos, em regime de aerobiose e anaerobiose, empregado no presente estudo. .48

Figura 4.2 - Plasmídeo pRS406 utilizado para se obter o fragmento de 523 pb empregado para reconstrução do gene URA3 nas linhagens auxotróficas para a uracila.

Figura 4.3 - Plasmídeo pUGhphN utilizado para se obter o cassete de transformação com 1949 pb para deleção da cópia extra do gene AGT1 na linhagem IMM-008 (iSUC2 evoluída $\Delta$ agt1).

Figura 4.4 - Plasmídeo pUG6-TPI1prom utilizado para se obter o cassete de transformação com 2301 pb para obtenção da linhagem que superexpressa o gene MAL13 por ação do promotor forte $\mathrm{P}_{T P I 1}\left(\mathrm{IMI}-066\right.$; iSUC2 $\left.\mathrm{P}_{T P I T}-M A L 13\right)$ 63

Figura 4.5 - Plasmídeo pAG306GPD-MAL11 utilizado para se obter o cassete de transformação com 7725 pb para obtenção da linhagem que superexpressa uma cópia extra do gene $A G T 1$ por ação do promotor forte $\mathrm{P}_{T D H 3}\left(\mathrm{IMI}-067\right.$; iSUC2 $\left.\mathrm{P}_{T D H 3} A G T 1\right)$. .64

Figura 5.1 - Atividade de invertase nas linhagens SUC2 ura- e iSUC2 ura-. .78

Figura 5.2 - Atividade de transporte de $\left[\mathrm{U}^{14}{ }^{14} \mathrm{C}\right]$ sacarose nas linhagens SUC2 ura- e iSUC2 ura-.

Figura 5.3 - Cultivos descontínuos (em frasco agitado) com as linhagens SUC2 ura- (A, C) e iSUC2 ura- $(B, D)$.

Figura 5.4 - Perfil de $\mathrm{CO}_{2}$ no gás de saída em cultivos descontínuos com as linhagens SUC2 (linhas pretas tracejadas); iSUC2 (linhas pretas sólidas); e iSUC2 $\triangle$ agt1 (linhas cinzas). .90

Figura 5.5 - Cultivos descontínuos em anaerobiose plena com as linhagens $\operatorname{SUC2}(\mathrm{A}, \mathrm{C})$ e iSUC2 (B,D). 92

Figura 5.6 - Atividade de invertase nas linhagens SUC2, iSUC2 e iSUC2 evoluída. 96

Figura 5.7 - Atividade de co-transporte de sacarose com $\mathrm{H}^{+}$nas linhagens SUC2, iSUC2, iSUC2 evoluída, iSUC2 evoluída $\Delta a g t 1$, iSUC2 evoluída $\Delta / \Delta a g t 1$, iSUC2 $\mathrm{P}_{T D H 3} A G T 1$, iSUC2 $\mathrm{P}_{T P I 1^{-}}$ 
MAL13. A atividade de transporte foi determinada em células coletadas durante o estadoestacionário de quimiostatos limitados por sacarose em anaerobiose. 100

Figura 5.8 - Conteúdo de carboidratos de reserva em células de levedura, coletadas durante o estado estacionário de quimiostatos anaeróbios limitados por sacarose. 101

Figura 5.9 - Experimento de evolução com a linhagem iSUC2. 103

Figura 5.10 - Verificação da presença, bem como confirmação da deleção do gene AGT1 nas linhagens iSUC2 (A), iSUC2 $\triangle a g t 1$ (B), iSUC2 evoluída (C), iSUC2 evoluída $\triangle a g t 1$ (D) e iSUC2 evoluída $\Delta / \Delta \operatorname{agt1}(\mathrm{E})$. 105

Figura 5.11 - Cultivos descontínuos em anaerobiose plena com a linhagem iSUC2 evoluída.

Figura 5.12 - Cinéticas de transporte de sacarose para as linhagens iSUC2 (O) e iSUC2 evoluída (๑) 


\section{LISTA DE TABELAS}

Tabela 2.1 - Principais parâmetros fisiológicos de S. cerevisiae (linhagem 248 UNSW 703100) durante o crescimento em sacarose ou em misturas de glicose e frutose, sob regime de aerobiose.

Tabela 4.1 - Linhagens utilizadas neste projeto. 45

Tabela 4.2 - Primers utilizados. 60

Tabela 5.1 - Parâmetros fisiológicos da linhagem SUC2 ura- (CEN.PK113-5D) durante o estado estacionário em quimiostatos aeróbios limitados por diferentes nutrientes. 71

Tabela 5.2 - Parâmetros fisiológicos teóricos, para o crescimento de S. cerevisiae em quimiostatos limitados por sacarose em plena anaerobiose $\left(D=0,10 \mathrm{~h}^{-1}\right)$.... .77

Tabela 5.3 - Parâmetros fisiológicos das linhagens SUC2 ura- (referência) e iSUC2 ura(ausência de invertase extracelular e super-expressão da invertase intracelular) durante o estado estacionário em quimiostatos limitados por sacarose ou glicose em aero- ou anaerobiose.

Tabela 5.4 - Parâmetros fisiológicos das linhagens SUC2 (CEN.PK113-7D, linhagemreferência), iSUC2 (ausência de invertase extracelular e super-expressão da invertase intracelular; IMI-056), iSUC2 evoluída (linhagem evoluída obtida em quimiostatos anaeróbios longos limitados por sacarose, a partir da linhagem iSUC2; IMM-007), iSUC2 evoluída $\triangle a g t 1$ (IMM-008), iSUC2 evoluída $\Delta / \Delta$ agt1 (IMM-009), iSUC2 $\mathrm{P}_{\text {TPII }}-M A L 13$ (IMI-066) e iSUC2 $\mathrm{P}_{\text {TDH }}$ AGT1 (IMI-067) durante o estado estacionário em quimiostatos anaeróbios limitados por sacarose.

Tabela 5.5 - Lista de alguns genes (envolvidos no metabolismo de sacarose) com expressão aumentada na linhagem iSUC2 evoluída em relação à iSUC2, durante o estado-estacionário de quimiostatos anaeróbicos limitados por sacarose.

Tabela 5.6 - Lista dos 9 genes com expressão diminuida na linhagem iSUC2 em relação à SUC2 (linhagem-refeência), durante o estado-estacionário de quimiostatos anaeróbicos limitados por sacarose. 


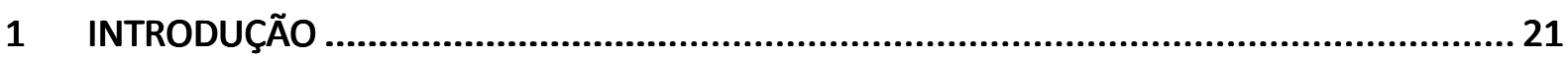

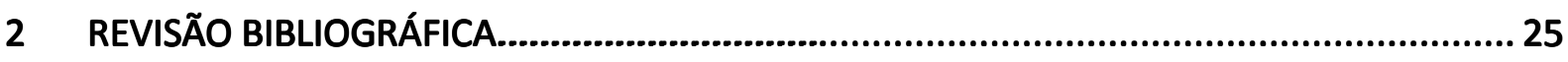

2.1 Engenharia Metabólica de S. cerevisiae para o melhoramento da produção de etanol combustível 25

2.2 A Engenharia Evolutiva como ferramenta complementarà Engenharia Metabólica 27

2.3 Metabolismo de sacarose em S. cerevisiae...................................................... 30

2.3.1 Via extracelular e via intracelular............................................................. 30

2.3.2 Transporte ativo de sacarose através da membrana plasmática de leveduras.....

2.3.3 Regulação gênica dos loci MAL ............................................................... 35

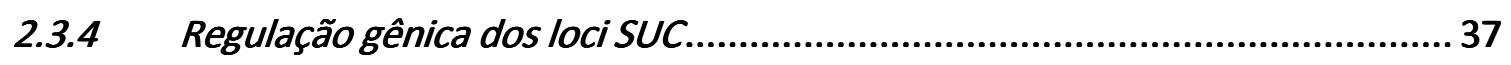

2.4 Fisiologia quantitativa de $S$. cerevisiae durante o crescimento em sacarose ou em

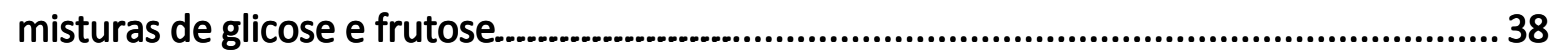

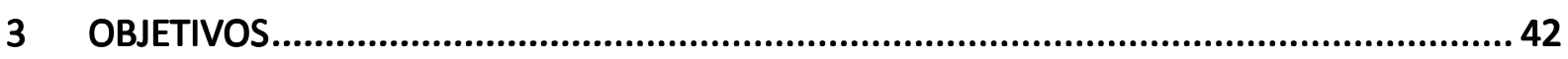

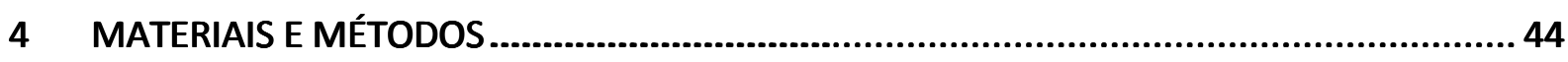

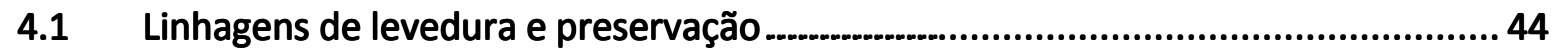

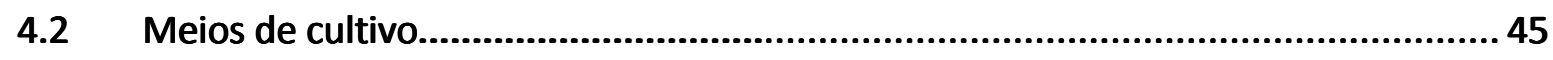

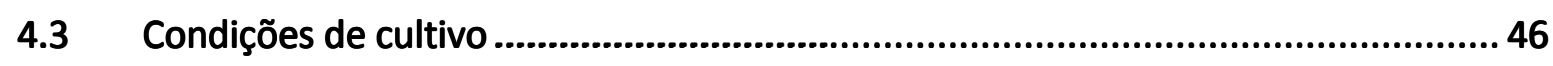

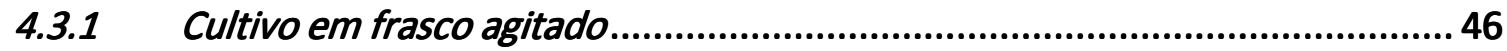

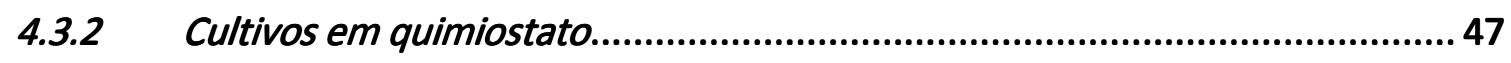

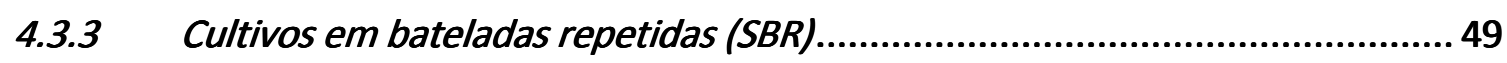

4.4 Determinação da fração molar de $\mathrm{O}_{2}$ e $\mathrm{CO}_{2}$ no gás de saída do biorreator................. 50

4.5 Quantificação da concentração de metabólitos extraœlulares e intracelulares ...... 50

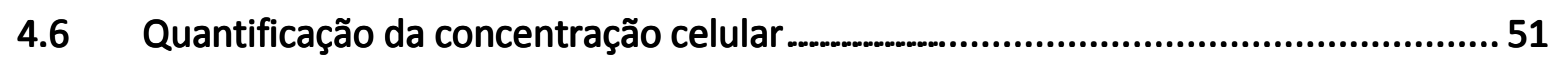

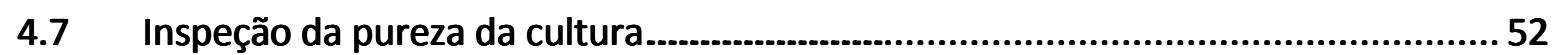

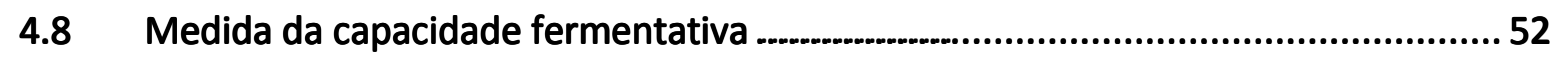

4.9 Determinação da atividade de invertase extracelulare total .................................5 52

4.10 Determinação da atividade do transporte de sacarose......................................... 53

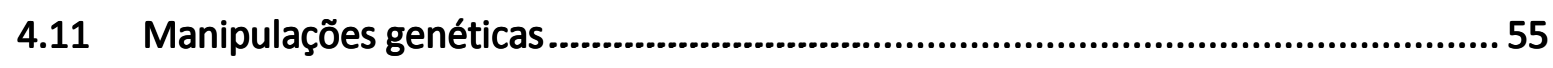

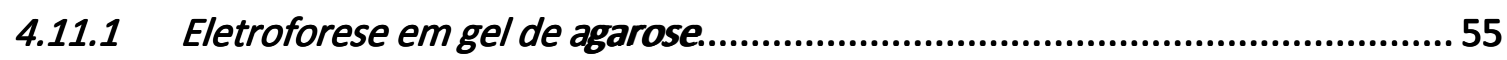




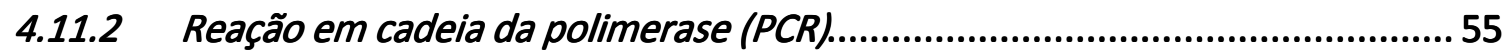

4.11.3 Transformação de leveduras pelo método do acetato de lítio ......................... 55

4.11.4 Reconstituição do gene URA3................................................................... 56

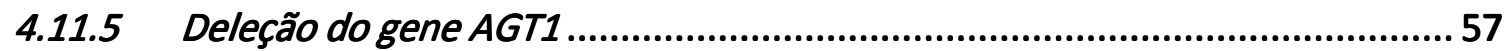

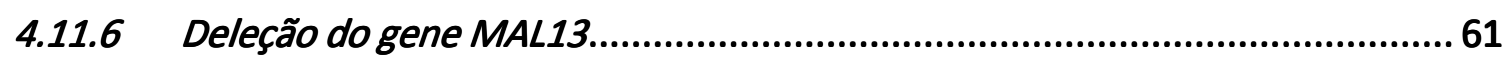

4.11.7 Substituição do promotor do gene MAL13................................................... 62

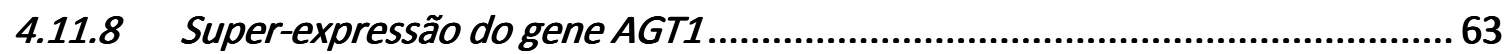

4.12 Análise da expressão gênica em escala genômica (transcriptoma) ........................ 64

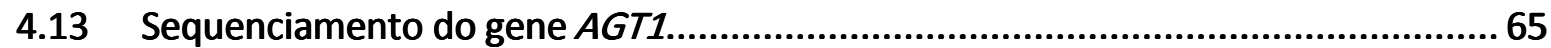

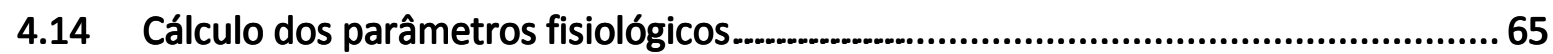

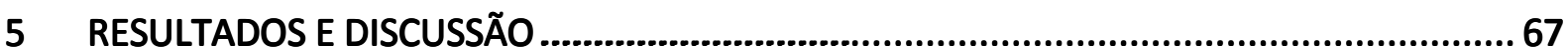

5.1 Efeitos da limitação por uracila em cultivos contínuos de $S$. cerevisiae....................69

5.2 Estudo da relocalização do metabolismo da sacarose em cultivos contínuos.......... 74

5.2.1 Modelo teórico do metabolismo de sacarose em anaerobiose........................ 74

5.2.2 Fisiologia das linhagens iSUC2 ura-e SUC2 ura- em quimiostatos limitados por sacarose ou glicose em aero- ou anaerobiose.......................................................... 77

5.3 Comparação das linhagens SUC2 e iSUC2 em cultivos descontínuos......................... 86

5.3.1 Cultivos descontínuos em frasco agïtado..................................................... 86

5.3.2 Cultivos descontínuos em anaerobiose plena.............................................. 89

5.4 Engenharia evolutiva para o melhoramento do transporte de sacarose em $S$.

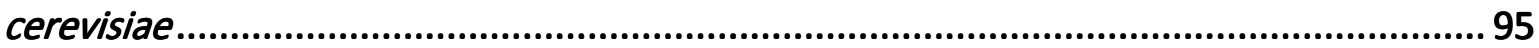

5.4.1 Fisiologia de S. cerevisiae SUC2 e iSUC2 prototróficas em quimiostatos

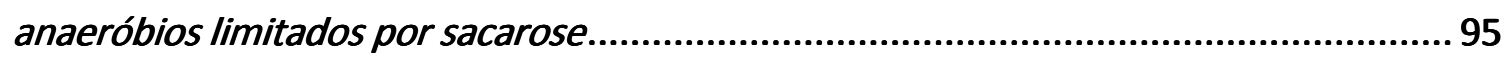

5.4.2 Engenharia evolutiva aplicada à linhagem iSUC2...................................... 102

5.4.3 Análise do transportador Agt1p na linhagem iSUC2 evoluída........................ 105

5.4.4 Cultivos descontínuos com a linhagem iSUC2 evoluída................................ 109

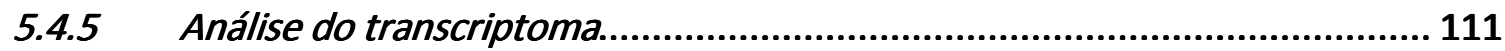

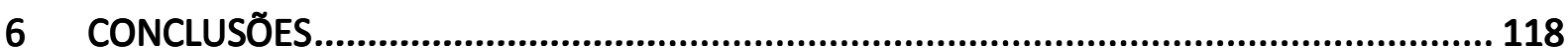

6.1 Efeito da limitação por uracila em cultivos contínuos...................................... 118

6.2 Impactos fisiológicos oriundos da relocalização da enzima invertase...................... 118

6.3 Aplicação da engenharia evolutiva como estratégia para o melhoramento do

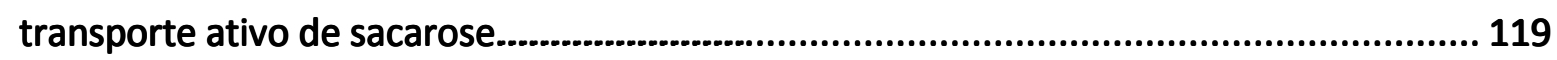


6.4 Sugestões para continuidade do trabalho. 120

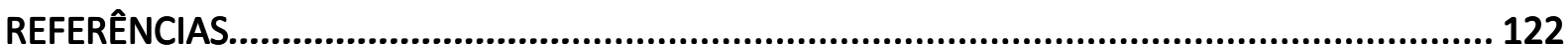

ANEXO A - Lista dos genes com expressão aumentada na linhagem iSUC2 evoluída em relação à i SUC2 parental. 134 


\section{INTRODUÇÃO}

A produção mundial de etanol combustível está em torno de 75 bilhões de litros por ano, e a maior parte deste total (cerca de 95\%) é produzida pela fermentação de determinados açúcares pela levedura Saccharomyces cerevisiae (Renewable Fuels Association, 2011). O Brasil é hoje o segundo maior produtor e o primeiro maior exportador mundial de etanol, com uma produção de 26 bilhões de litros na safra de 2009/2010. O setor sucro-alcooleiro movimenta cerca de $2 \%$ do PIB brasileiro, assegurando milhões de empregos diretos e indiretos, permitindo ao Brasil ser o único país a implantar em larga escala um programa de combustível alternativo ao petróleo, com muitas vantagens ambientais, econômicas e sociais (Ministério da Agricultura, Pecuária e Abastecimento, 2011). Apesar de os EUA serem os maiores produtores mundiais de etanol, naquele país este combustível é produzido a partir de amido de milho, principalmente, que resulta na obtenção de 1,3 equivalentes de energia para cada 1 equivalente de energia gasto no processo (balanço de energia líquida) (Tilman et al., 2008). Por outro lado, a produção de etanol a partir dos açúcares da cana-de-açúcar no Brasil resulta em 9,2 equivalentes de energia por cada equivalente gasto no processo (Macedo, 1996). Assim, esta forma de produção é muito mais sustentável que a anterior. Desta maneira, pode-se afirmar que o etanol é um dos produtos biotecnológicos mais importantes no cenário brasileiro e até mesmo mundial, quando se leva em conta os quesitos valor, quantidade e sustentabilidade. No entanto, para que o etanol produzido no país continue a ser o mais competitivo, é fundamental que se continue a investir no aprimoramento do processo de produção.

Substratos à base de sacarose, como o caldo de cana, o melaço ou uma mistura dois dois, constituem uma das principais matérias-primas para a obtenção de etanol no cenário mundial, especialmente no Brasil. Atualmente, os rendimentos da etapa fermentativa do processo de produção de etanol a partir de cana-de-açúcar são elevados, da ordem de $90 \%$ da conversão estequiométrica de $0,511 \mathrm{~g}$ etanol. ( $\mathrm{g}$ hexose) ${ }^{-1}$. Além disto, o processo encontra-se em estágio tecnológico bastante avançado. No entanto, mesmo pequenos aumentos no rendimento podem significar grandes aumentos em termos de lucratividade do processo e utilização eficiente da fonte de carbono, já que os volumes de produção são 
grandes e cerca de $60 \%$ do custo de produção do etanol deve-se ao custo da matéria-prima (Wyman e Hinman, 1990).

Como o etanol é um produto derivado diretamente do metabolismo central do carbono, sendo um metabólito primário, cuja formação está atrelada ao crescimento celular, muitas estratégias para se aumentar o fator de conversão de açúcares em etanol $\left[\mathrm{Y}_{\mathrm{ETH} / \mathrm{S}} ; \mathrm{g}\right.$ etanol produzido. (g açúcar consumido ${ }^{-1}$ )], baseiam-se na alteração do metabolismo energético das leveduras. Uma das possíveis maneiras de se atingir tal objetivo é a introdução de modificações genéticas (no escopo da engenharia metabólica) que resultem em gasto adicional de ATP para a formação de uma mesma quantidade de biomassa (células), em comparação à linhagem selvagem. Desta forma, para compensar o maior custo energético da formação de biomassa, mais etanol é produzido para a mesma quantidade de açúcar consumido, já que no metabolismo fermentativo a geração de energia, na forma de ATP, é alcançada pela produção de etanol. Recentemente, o grupo de pesquisa liderado pelo Prof. Dr. Boris U. Stambuk, da Universidade Federal de Santa Catarina (UFSC), realizou alterações no metabolismo da sacarose em $S$. cerevisiae, no intuito de aumentar o fator de conversão deste dissacarídeo em etanol. Esta estratégia explora a forma como as leveduras metabolizam a sacarose.

Na levedura $S$. cerevisiae, são conhecidas duas formas pela qual a sacarose é metabolizada (Figura 1.1). Numa delas, a mais utilizada e bem descrita até o momento, a sacarose é hidrolisada no ambiente extracelular pela enzima invertase, produzindo glicose e frutose, as quais são posteriormente transportadas para o interior das células por difusão facilitada (sem gasto energético) pelos transportadores Hxtp, e posteriormente consumidas na via glicolítica. Na outra rota, menos caracterizada, a sacarose pode ser diretamente transportada através do co-transporte com íons $\mathrm{H}^{+}$, pelos transportadores Malx1p e Agt1p, e subsequentemente hidrolisada no ambiente intracelular por ação da enzima invertase intracelular ou por maltases (Carlson e Botstein, 1982; Santos et al., 1982; Stambuk et al., 2000). 


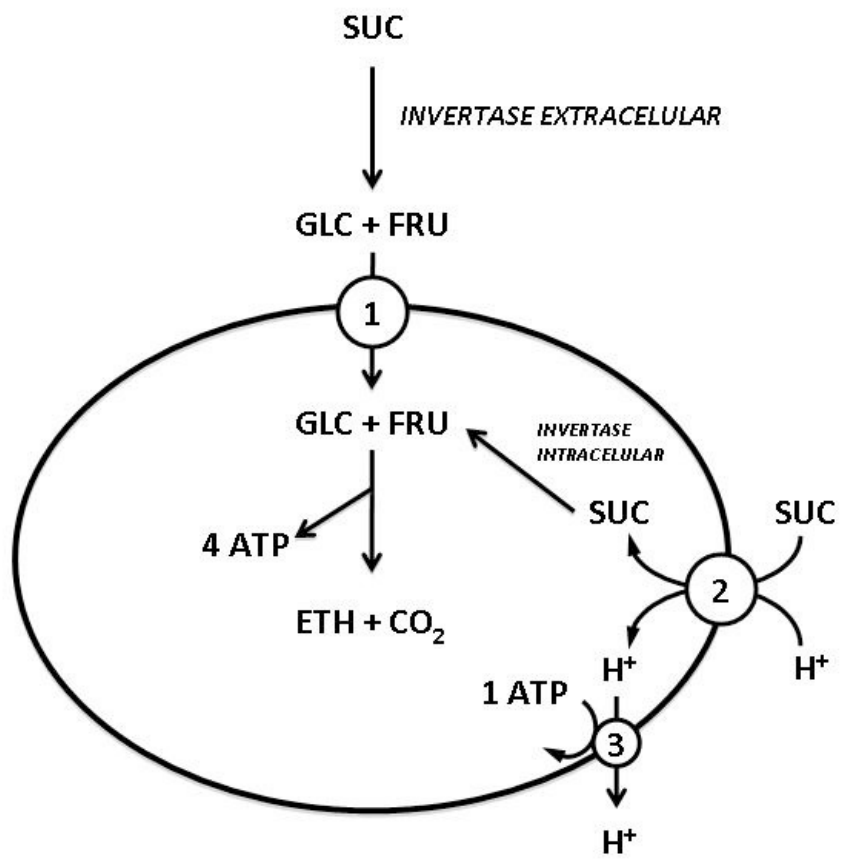

Figura 1.1 - Esquema resumido das duas vias (extra- e intracelular, mediadas pelas enzimas invertase extracelular e invertase intracelular, respectivamente) para o metabolismo da sacarose em $S$. cerevisiae. SUC: sacarose; GLC: glicose; FRU: frutose; ETH: etanol; 1: transportadores Hxtp; 2: transportadores Agt1p ou Malx1p; 3: $\mathrm{H}^{+}$-ATPase de membrana.

A estratégia concebida pelo grupo do Prof. Dr. Boris Stambuk baseia-se na seguinte hipótese: É de se esperar que uma levedura expressando apenas a forma intracelular da enzima invertase, quando cultivada em sacarose, seja obrigada a transportar este açúcar para o ambiente intracelular. Ao transportar uma molécula de sacarose para o ambiente intracelular, ocorre o co-transporte de $\mathrm{um} \mathrm{H}^{+}$, o que faz com que as células, para manterem o $\mathrm{pH}$ intracelular constante, tenham que bombear este próton para o ambiente extracelular. Isto ocorre via $\mathrm{H}^{+}$-ATPases de membrana, que gastam uma molécula de ATP por $\mathrm{H}^{+}$ extrudado (Figura 1.1). Como balanço final, para cada mol de sacarose consumido pelas células em anaerobiose (ou durante metabolismo fermentativo), em vez de serem gerados 4 moles de ATP via fermentação (o que ocorreria no caso de hidrólise extracelular da sacarose e transporte de glicose e frutose por difusão facilitada), são gerados apenas 3 moles de ATP (já que um mol é gasto para extrudar $\mathrm{o} \mathrm{H}^{+}$co-transportado). Nesta situação, o que se espera é que as células, quando em anaerobiose, procurem repor estes $25 \%$ de ATP (ou ao menos parte disto) que deixam de ser gerados, através de um aumento no fluxo de carbono para as vias fermentativas, ou seja, para a formação de etanol. Portanto, o que se imagina é que este cenário leve à formação de mais etanol por mol de sacarose consumido em anaerobiose 
do que numa situação de hidrólise extracelular. Para verificar esta hipótese, o gene SUC2 de uma levedura da espécie $S$. cerevisiae foi alterado de forma que a linhagem resultante, denominada iSUC2 ura- (BSY021-34B), expressasse, por ação do promotor forte $\mathrm{P}_{A D H 1}$, apenas a forma intracelular da enzima invertase (Stambul et al., 2009).

O presente trabalho de doutoramento, como uma continuidade deste trabalho de engenharia metabólica inicial, buscou avaliar de forma quantitativa a eficácia desta estratégia. Para isto, foi amplamente explorada a técnica de cultivo em quimiostato. Além de uma avaliação fisiológica inicial de linhagens que superexpressam a invertase intracelular, buscou-se verificar se era possível aumentar a afinidade/capacidade dos transportadores de sacarose nesta linhagem pelo uso de uma estratégia de melhoramento genético denominada engenharia evolutiva, a qual se baseia na obtenção de mutantes através da imposição de uma ou mais pressões seletivas sobre uma determinada população de microrganismos, no intuito de selecionar mutantes com fenótipo melhorado. Além disto, através do uso da transcriptômica, procurou-se elucidar as causas para o fenótipo melhorado obtido e, posteriormente, usando-se a tecnologia do DNA recombinante, introduzir as modificações genéticas mais apropriadas (engenharia reversa), de forma a mimetizar o processo evolutivo que resultou numa linhagem melhorada em termos do fator de conversão de sacarose a etanol. 


\section{REVISÃO BIBLIOGRÁFICA}

\subsection{Engenharia Metabólica de $S$. cerevisiae para o melhoramento da produção de etanol combustível}

Existe atualmente um esforço global no campo do etanol combustível no sentido de expandir o espectro de substratos utilizados pela levedura S. cerevisiae (Galazka et al., 2010; Kuyper et al., 2003, 2004, 2005a, 2005b; Wisselink et al., 2007, 2009), bem como de aumentar o rendimento da fermentação alcoólica (Bro et al., 2006; Guo et al., 2011; Medina et al., 2010; Nissen et al., 2000). Apesar de os rendimentos deste processo industrial já serem elevados [acima de $90 \%$ do valor estequiométrico de $0,511 \mathrm{~g}$ de etanol. ( $\mathrm{g}$ de glicose)

${ }^{1}$ ] e o processo estar em estágio tecnológico bastante avançado, sabe-se que mesmo pequenos aumentos no rendimento podem significar grandes aumentos em termos de lucratividade do processo e utilização eficiente da fonte de carbono, já que cerca de $60 \%$ do custo de produção do etanol é dado pela matéria-prima (Wyman e Hinman, 1990) e a produção anual mundial é da ordem de dezenas de bilhões de litros atualmente, com perspectivas de expansão nos próximos anos (Renewable Fuels Association, 2011).

Como o etanol é um produto derivado diretamente do metabolismo central do carbono (metabólito primário), muitas estratégias para se aumentar o rendimento e/ou a produtividade da fermentação alcoólica baseiam-se em aumentar a proporção de carbono convertido em etanol, e/ou aumentar a velocidade desta conversão, respectivamente, através do uso da engenharia metabólica (Stephanopoulos et al., 1998).

Num dos trabalhos nesta área, Nissen et al. (2000) mostraram que, reduzindo-se a formação do excesso de NADH (resultante das vias biossintéticas e normalmente reoxidado pela formação de glicerol) e aumentando-se o consumo de ATP na biossíntese, foi possível aumentar em $10 \%$ o rendimento em etanol, bem como reduzir em $14 \%$ o rendimento em biomassa sobre a fonte de carbono. Para tanto, foi necessária a substituição da via normal da síntese de glutamato a partir de amônia (que consome NADPH), por uma via alternativa na qual ATP e NADH são consumidos. A estratégia utilizada foi alcançada pela deleção do gene GDH1 (que codifica a enzima glutamato desidrogenase, envolvida na via normal de 
síntese de glutamato) e concomitante superexpressão dos genes GLN1 e GLT1 (que codificam as enzimas glutamato sintetase e glutamato sintase, respectivamente, envolvidas na via alternativa da síntese de glutamato). No entanto, uma possível desvantagem desta estratégia é que normalmente os meios industriais contém aminoácidos como fonte de nitrogênio e tal estratégia depende da assimilação da amônia para se atingir os rendimentos apresentados.

Em outro trabalho em que houve alteração do balanço de redox em $S$. cerevisiae, Bro et al. (2006) demonstraram que a expressão da enzima heteróloga não fosforilante gliceraldeido-3P-desidrogenase dependente de $\mathrm{NADP}^{+}$(NADP ${ }^{+}$-GAPN) foi suficiente para reduzir em $40 \%$ o rendimento em glicerol, o que acarretou num aumento de $3 \%$ no rendimento em etanol. Em teoria, nesta estratégia, a conversão de gliceraldeído-3P para glicerato-3P pela enzima NADP ${ }^{+}$-GAPN, substitui a formação de glicerol, pois, como nesta via alternativa não há geração de $\mathrm{NADH}, \mathrm{o} \mathrm{NADH}$ formado nas vias biossintéticas, é reoxidado através da formação de etanol. Por sua vez, o NADPH gerado durante a conversão de gliceráldeido-3P para glicerato-3P é consumido pelas vias biossintéticas. Cabe destacar que a conversão de gliceráldeido-3P para glicerato-3P, pelas enzimas $N A D^{+}$-gliceraldeído-3Pdesidrogenase (GAPDH) e fosfo-glicerato-quinase (PGK), continua operante nas células, uma vez que na via alternativa o rendimento em ATP é nulo. Assim a via normal é a responsável por garantir o suprimento de energia às células crescendo em anaerobiose.

Uma estratégia elegante para o aumento do rendimento em etanol foi proposta recentemente por Medina et al. (2010), na qual o acetato foi utilizado como aceptor de elétrons na reoxidação de NADH em uma linhagem incapaz de produzir glicerol (deletada nos genes GPD1 e GPD2) e que expressa a enzima heteróloga acetaldeído desidrogenase dependente de $\mathrm{NAD}^{+}$. Com isto, um composto resultante da hidrólise de resíduos lignocelulósicos, que é um conhecido inibidor da atividade de leveduras (o acetato), pode ser convertido em etanol e ainda permitir a eliminação completa da formação de glicerol em cultivos anaeróbios com glicose.

Além de modificar o rendimento de um determinado produto de interesse industrial, a engenharia metabólica pode ser empregada com o objetivo de se aumentar a velocidade de uma determinada via metabólica. Neste caso, os alvos das alterações genéticas são normalmente genes regulatórios, ou seja, genes envolvidos no controle da expressão gênica dentro da via em estudo. Um exemplo de tal conceito é o trabalho desenvolvido por 
Ostergaard et al. (2000), cujo objetivo foi aumentar a velocidade de consumo de galactose pela alteração da rede de regulação dos genes GAL. Com a remoção dos genes GAL80, GAL6 e MIG1 (envolvidos na repressão dos genes estruturais do metabolismo de galactose; GAL1, $G A L 2, G A L 4, G A L 10$ ) atingiu-se um aumento de $41 \%$ na velocidade específica de consumo de galactose em relação à linhagem-referência.

Através dos exemplos acima, pode-se notar que existem diversas estratégias para se aumentar o $Y_{\mathrm{ETH} / \mathrm{S}}$ (fator de conversão da fonte de carbono em etanol) através da manipulação dos genes envolvidos no metabolismo central do carbono e/ou de outros genes. Estas alterações genéticas podem envolver tanto genes estruturais, como genes regulatórios. No entanto, não pudemos encontrar nenhum trabalho na literatura, no qual a energética do transporte da fonte de carbono foi empregada como forma de se aumentar o rendimento em etanol.

\subsection{A Engenharia Evolutiva como ferramenta complementarà Engenharia Metabólica}

O termo "Evolutionary Engineering" (neste texto, traduzido como Engenharia Evolutiva) tem sido empregado com frequência nos últimos anos, para designar uma estratégia de melhoramento de microrganismos que é baseada no princípio da variação e seleção natural, conforme proposto originalmente por Charles Darwin em sua Teoria da Origem das Espécies (Sauer, 2001). Assim, desde que seja possível impor a pressão seletiva adequada em laboratório, torna-se viável "forçar" um fenótipo desejado ao microrganismo em estudo. Esta estratégia representa uma alternativa ou uma complementação à Engenharia Metabólica (Stephanopoulos et al., 1998), que se baseia em modificações genéticas dirigidas na busca de um fenótipo desejado, ao contrário da Engenharia Evolutiva, que busca o fenótipo desejado através da imposição de uma ou mais pressões seletivas, contando com a ocorrência de mutações e de seleção natural.

Com freqüência, Engenharia Evolutiva e Engenharia Metabólica são combinadas, com o objetivo de se obter microrganismos melhorados. A abordagem clássica consiste em primeiramente introduzir um ou mais genes heterólogos no microrganismo em estudo, conferindo ao mesmo uma determinada capacidade que ele originalmente não possuía, dentro do escopo da Engenharia Metabólica. Em seguida, procede-se com a Engenharia Evolutiva, através de experimentos longos com uma população do microrganismo em 
estudo, em que várias gerações transcorrem, aumentando-se a probabilidade de ocorrerem mutações. O fenótipo desejado, neste caso, pode ser, por exemplo, uma maior tolerância a fatores como oxigênio ou altas concentrações de glicose. Assim, a pressão seletiva é imposta através do aumento gradativo da concentração de oxigênio ou de glicose, respectivamente, no caso destes exemplos.

A obtenção de linhagens de levedura evoluídas em laboratório é uma estratégia comprovadamente eficiente para diversas finalidades. Como exemplos, podemos citar a otimização do transporte de maltose em cultivos aeróbios longos em quimiostato (Jansen et al., 2004); a metabolização de xilose e arabinose em anaerobiose plena utilizando-se tanto bateladas repetidas como quimiostatos (Kuyper et al., 2004, 2005a, 2005b; Sonderegger e Sauer, 2003; Wisselink et al., 2007, 2009), o aumento da tolerância ao etanol (Brown e Oliver, 1982). As ferramentas podem ser tanto cultivos descontínuos em série (bateladas repetidas), como quimiostatos, dependendo dos objetivos do estudo. O fato é que uma população de microrganismos, que frequentemente contém milhões de indivíduos num mililitro, os quais se duplicam num intervalo de poucas horas, após várias gerações, acaba sofrendo mutações e, dentro de um ambiente que confere pressão seletiva, passará também por seleção para os indivíduos com melhores condições de desenvolvimento neste ambiente. Desta maneira, as células menos adaptadas serão eliminadas destes sistemas de cultivo; nas bateladas repetidas, a cada vez que se renova o meio, e nos quimiostatos, continuamente pelo sistema de retirada de meio. Alguns exemplos ilustrativos são apresentados a seguir.

A produção de etanol apartir de fontes ligno-celulósicas requer a fermentação da fração hemi-celulósica, a qual é rica em pentoses, tais como xilose e arabinose. Entretanto, o crescimento de linhagens de $S$. cerevisiae modificadas geneticamente para a metabolização de xilose geralmente é comprometido por problemas no balanço redox dos cofatores $\mathrm{NAD}^{+} \mathrm{e}$ $\mathrm{NADP}^{+}$das enzimas xilose redutase e xilose desidrogenase, ou pela baixa atividade de xilose isomerase. Neste contexto, Sonderegger e Sauer (2003) demonstraram a aplicação da engenharia evolutiva para a seleção de uma linhagem de $S$. cerevisiae capaz de crescer em xilose sob condições de anaerobiose. Primeiramente, uma linhagem recombinante (expressando as enzimas xilose redutase e xilose desidrogenase), capaz de crescer eficientemente em xilose sob condições de aerobiose foi lentamente adaptada, em regime de quimiostato, para crescer em condições de microaerobiose, para depois ser submetida à 
situação de anaerobiose plena. Tal procedimento, que totalizou 260 gerações de seleção, é um forte indicativo de que múltiplas mutações foram necessárias para obtenção deste novo fenótipo.

Kuyper et al. (2004) demonstraram a possibilidade do uso de estratégias de engenharia metabólica aliadas à engenharia evolutiva para obtenção de uma linhagem de $S$. cerevisiae capaz de converter eficientemente xilose em etanol. Para tanto, uma linhagem expressando a enzima xilose isomerase foi submetida a transferências seriadas, em meio contendo xilose como única fonte de carbono. Desta forma, um mutante com velocidade específica máxima de crescimento notavelmente maior $\left(\mu_{\max }=0,18 \mathrm{~h}^{-1}\right)$ do que a linhagem inicial $\left(\mu_{\max }=0,005 \mathrm{~h}^{-1}\right.$ ) foi obtido. Como este mutante não foi capaz de crescer sob condições de plena anaerobiose, uma nova seleção em regime de bateladas repetidas foi iniciada, sob condições crescentes de limitação de oxigênio até o ponto de plena anaerobiose. Ao final dessa seleção, obteve-se um mutante capaz de crescer em xilose $\left(\mu_{\max }\right.$ $\left.=0,03 \mathrm{~h}^{-1}\right)$, sob condições estritas de anaerobiose. Mesmo após a superexpressão de determinados genes da via das pentoses-fosfato nesta linhagem evoluída, a linhagem resultante apresentou baixa velocidade específica de consumo de xilose quando cultivada em meio contendo uma mistura de xilose e glicose (Kuyper et al., 2005a). Para melhorar este fenótipo, a linhagem foi inicialmente submetida a um cultivo anaeróbico em quimiostato em meio limitado por xilose, seguido de uma série de cultivos em regime de bateladas repetidas, em meio contendo glicose e xilose. Com isto, uma nova linhagem evoluída foi obtida, a qual mostrou-se capaz de crescer eficientemente sob anaerobiose em meio formado pela mistura destes dois açúcares. Cabe destacar que a cinética de assimilação da xilose pela linhagem evoluída $\left[V_{\max }=32 \mathrm{mmol} .(\mathrm{g} D W . \mathrm{h})^{-1}\right.$ e $K_{\mathrm{m}}=99 \mathrm{mM}$ ] foi notavelmente maior do que para a linhagem inicial [ $V_{\max }=16$ mmol.(g.h ${ }^{-1}$ e $K_{\mathrm{m}}=132 \mathrm{mM}$ ] (Kuyper et al., 2005b).

Com a finalidade de permitir a conversão de arabinose em etanol sob condições de plena anaerobiose, Wisselink et al. (2007) utilizaram uma combinação de engenharia metabólica com engenharia evolutiva. Num primeiro momento, dentro do escopo da engenharia metabólica, introduziram os genes bacterianos ( $\operatorname{ara} A$, $\operatorname{ara} B$ e $\operatorname{ara} D$ ) que permitem a conversão de L-arabinose em D-xilulose-5-P na levedura S. cerevisiae (Becker e Boles, 2003). No entanto, esta estratégia não resultou em crescimento em meio sintético contendo arabinose como única fonte de carbono. Para contornar este problema, fizeram uso da 
engenharia evolutiva, inicialmente por meio de transferências seriadas em meio sintético contendo uma mistura de galactose (indutor da expressão do gene $G A L 2$, que codifica um transportador de galactose e arabinose) e arabinose, e depois, em meio contendo somente arabinose. Nesta primeira etapa, conseguiram obter um isolado com $\mu_{\max }$ de $0,15 \mathrm{~h}^{-1}$, porém incapaz de produzir etanol. Num segundo estagio de seleção, empregando-se cultivos descontínuos em série (com diminuição gradual do suprimento de oxigênio), obtiveram um isolado capaz de converter arabinose em etanol sob plena anaerobiose com um $\mathrm{Y}_{\mathrm{ETH} / \mathrm{s}}$ de $0,43 \mathrm{~g} \cdot \mathrm{g}^{-1}$ e uma produtividade específica de etanol de 1,9 mmol.(g DW.h $)^{-1}$.

\subsection{Metabolismo de sacarose em S. cerevisiae}

\subsubsection{Via extracelular e via intracelular}

Sabe-se atualmente que na levedura $S$. cerevisiae existem duas vias metabólicas para a utilização da sacarose (Figura 1.1). Numa delas, conhecida como a via extracelular, a sacarose é hidrolisada no ambiente extracelular (mais precisamente, no espaço periplasmático) pela enzima invertase (codificada pelos genes SUC), gerando glicose e frutose, que são subsequentemente transportadas para o interior das células através das permeases Hxtp (Lagunas, 1993) e metabolizadas pela via glicolítica. Na segunda via, a via intracelular, a sacarose é primeiramente transportada através da membrana plasmática e em seguida hidrolisada no interior das células. Este transporte ocorre via co-transporte de íons $\mathrm{H}^{+}$, e implica portanto num gasto de energia para a manutenção do $\mathrm{pH}$ intracelular através do bombeamento de prótons para o ambiente extracelular pelas $\mathrm{H}^{+}$-ATPases da membrana plasmática (Carlson e Botstein, 1982; Santos et al., 1982; Stambuk et al., 2000).

As $\mathrm{H}^{+}$-ATPases (codificadas pelos genes PMA1 e PMA2 na levedura S. cerevisiae) é uma proteína de $100 \mathrm{kDa}$, ancorada na camada bi-lipídica da membrana plasmática, que bombeia $\mathrm{H}^{+}$para fora da célula através da clivagem de ATP, com estequiometria 1:1. Acredita-se que normalmente este mecanismo consuma cerca de $25 \%$ de todo ATP produzido pelas células, para bombear $\mathrm{H}^{+}$e assim gerar o gradiente eletroquímico que governa a captação $\mathrm{H}^{+}$-dependente de nutrientes (Ambesi et al., 2000; Serrano et al., 1986). 
Leveduras que contenham qualquer um dos genes SUC (SUC1-SUC5 e SUC7) são capazes de produzir a enzima invertase (Carlson e Botstein, 1983a). Na verdade, o gene SUC é responsável pela síntese de dois fragmentos de RNA. Um transcrito maior (1,9 kb), contendo a seqüência sinal, que codifica a enzima glicosilada extracelular, e outro menor (1,8 kb), que codifica a enzima não-glicosilada intracelular (Carlson e Botstein, 1982; Carlson e Botstein, 1983b; Grossmann e Zimmermann, 1979). Os dois RNAs são transcritos na mesma direção, e diferem apenas na região do início da transcrição (porção 5'), a qual codifica o peptídeo sinal para a secreção e glicosilação da enzima extracelular (Figura 2.1). Os níveis da versão extracelular da enzima são controlados pela repressão por glicose, enquanto a versão intracelular é praticamente insensível ao controle pela glicose e expressada constitutivamente. Todavia, na ausência de repressão por glicose, a fração extracelular é a fração majoritária da atividade total de invertase (>90\%), e desta forma, postula-se que a via de utilização da sacarose pela invertase extracelular seja a rota principal no metabolismo deste dissacarídeo por S. cerevisiae (Carlson e Botstein, 1982; Gascón e Lampen, 1968).

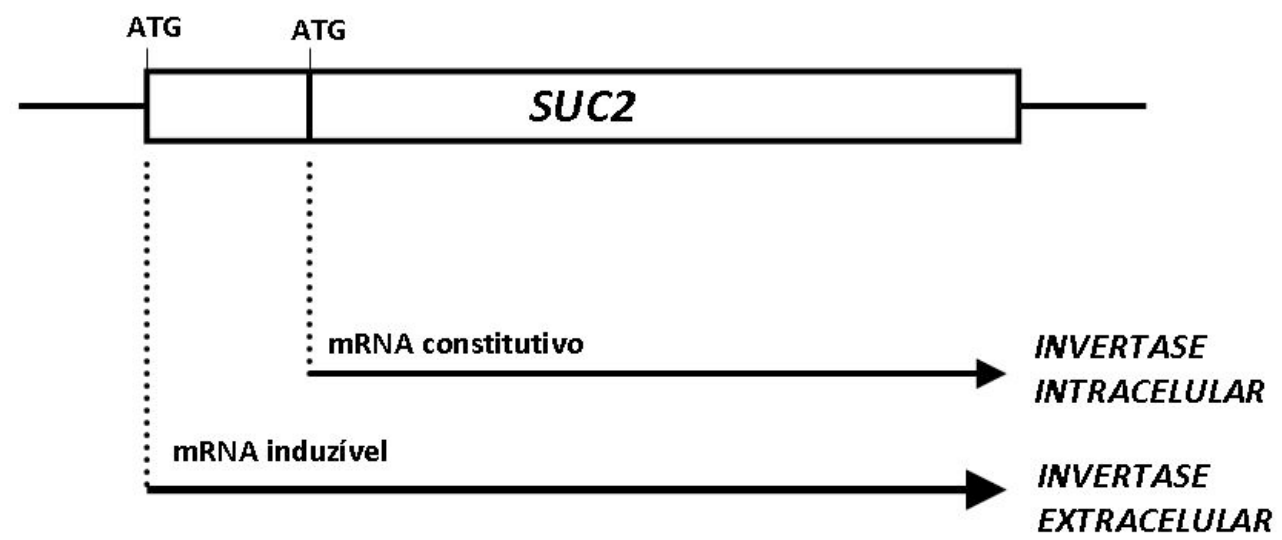

Figura 2.1 - Esquema da estrutura genética do gene SUC2 em $S$. cerevisiae. As setas indicam os mRNAs, relativos às duas invertases, extracelular (cuja expressão gênica é induzível) e intracelular (cuja expressão é constitutiva).

Fonte: Adaptado de Carlson e Botstein, 1982.

\subsubsection{Transporte ativo de sacarose através da membrana plasmática de leveduras}

O primeiro trabalho a demonstrar a possibilidade de transporte ativo da sacarose por células de levedura foi o de Santos, et al. (1982). Neste trabalho pioneiro, foi demonstrado 
que o transporte de sacarose pelas células é mediado pelo co-transporte com íons $\mathrm{H}^{+}$, sendo assim dependente do gradiente eletroquímico de $\mathrm{H}^{+}$através da membrana plasmática. No entanto, não se soube precisar exatamente a identidade do(s) transportadore(s) envolvido(s). Todavia, de acordo com o perfil cinético do transporte, pode-se afirmar que mais de um sistema de transporte estaria em ação. Outros trabalhos, anteriores ou posteriores ao estudo de Santos et al. (1982), também corroboram parte das constatações observadas por estes autores (Avigad, 1960; Klaassen e Raamsdonk, 1998; Mwesigye e Barford, 1996). Contudo, foi apenas mais tarde que Stambuk et al. (2000) demonstraram que o transporte de sacarose é realizado pelas permeases codificadas nos loci MAL. Mais precisamente, foi verificado que o transportador Agt1p compunha o sistema de alta afinidade para o transporte de sacarose $\left(K_{\mathrm{m}} \sim 8 \mathrm{mM}\right)$, enquanto que as permeases Malx1p (mais precisamente Mal21p) eram responsáveis pelo sistema de baixa afinidade $\left(K_{\mathrm{m}} \sim 120\right.$ mM). A propósito, a permease Agt1p já havia sido sugerida como sendo a principal transportadora de sacarose na levedura $S$. cerevisiae num trabalho anterior do mesmo grupo de pesquisa (Stambuk et al., 1999). Em vista dessas constatações, e utilizando uma linhagem incapaz de assimilar glicose e frutose (devido à deleção dos genes $H X T$ ), Batista et al. (2004) demonstraram que a sacarose pode ser eficientemente transportada e hidrolisada intracelularmente por S. cerevisiae, e que o seu transporte fica severamente comprometido quando o gene $A G T 1$ é removido desta linhagem, enfatizando a importância do transportador Agt1p durante a captação da sacarose. Estratégia semelhante havia sido previamente utilizada por Klaassen e Raamsdonk (1998).

Como se pode notar, os trabalhos relatados acima demonstraram que a via de utilização da sacarose por transporte ativo encontra-se intimamente relacionada ao metabolismo da maltose, bem como a de outros alfa-glicosídeos (maltotriose, trealose, alfametil-glicosídeo, etc), compartilhando assim o mesmo sistema de transporte e algumas vezes, o de hidrólise (ver abaixo). Apesar de sabermos hoje que o transporte de sacarose em S. cerevisiae é mediado pelos transportadores codificados pelos loci $M A L$, que constitui uma família de genes poliméricos (muitos genes para as mesmas funções), a grande maioria dos estudos sobre a caracterização genética e bioquímica destes genes foi feita empregando-se a maltose como substrato de estudo (Cheng e Michels, 1991; Han et al., 1995; Needleman, 1991; Stambuk e Araújo, 2001; Vanoni et al., 1989). 
Já foram descritos até o presente cinco diferentes loci $M A L$, todos localizados nas regiões teloméricas dos cromossomos VII (MAL1), III (MAL2), II (MAL3), XI (MAL4) e VIII (MAL6). Cada lócus contém ao menos uma cópia de três genes distintos, codificando uma permease (MALX1, onde $\mathrm{x}$ representa o lócus), uma alfa-glicosidase, ou também denominada "maltase" (MALx2) e uma proteína de regulação positiva (MALx3), necessária para a transcrição induzida pela maltose dos dois genes anteriores (Figura 2.2). Este último gene codifica uma proteína de regulação positiva que se liga à região inter-gênica entre os genes MALX1 e MALX2, induzindo as suas transcrições (em sentidos opostos). Adicionalmente, esta proteína também se liga à região promotora do seu próprio gene, induzindo sua transcrição (Needleman, 1991).

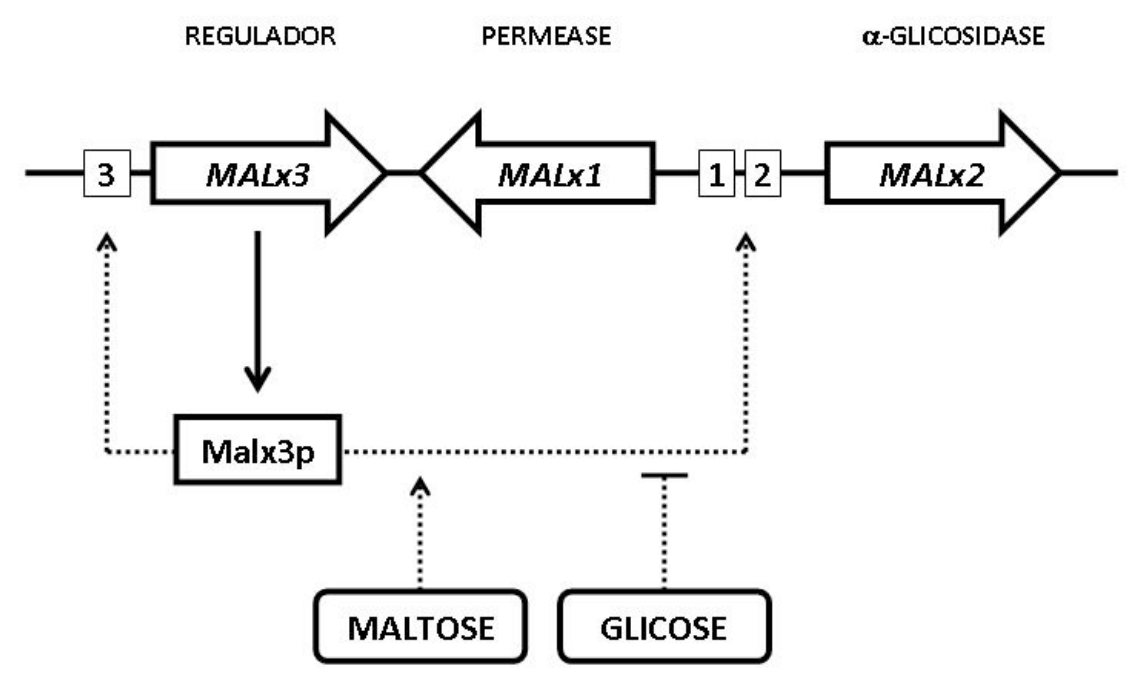

Figura 2.2 - Esquema geral da estrutura genética dos loci $M A L$ em $S$. cerevisiae. O gene MALx3 codifica a proteína de regulação positiva; o gene $M A L x 1$ codifica a permease (transportador); o gene $M A L x 2$ codifica a alfa-glicosidase (maltase). A proteína de regulação positiva (Malx3p), na presença de maltose, liga-se aos sítios 1 e $2\left(\mathrm{UAS}_{\mathrm{MAL}}\right)$, como também ao sítio 3. A glicose, por outro lado, reprime a atividade da Malx3p e a transcrição dos genes $M A L$ pela via de repressão catabólica, na qual a proteína Mig1p tem papel fundamental.

Fonte: Adaptado de Needleman, 1991.

Além dos loci $M A L$ descritos acima, nos quais todos os três genes são funcionais, já foram descritos outros alelos naturais ( $\mathrm{malg}, \mathrm{mal} / \mathrm{p}, \mathrm{ma} \rho$ ), contendo genes não funcionais, impossibilitando assim, por exemplo, a fermentação da maltose, em linhagens que somente possuem estes alelos (Naumov, 1994). Particularmente interessante para o transporte da sacarose, destaca-se um dos alelos do lócus MAL1, denominado MAL1g. Este lócus parece não conter atividade para o alelo regulador (MALx3), porém estão presentes os outros dois 
genes estruturais ( $M A L x 1$ e $M A L x 2)$. No entanto, um fato surpreendente deste distinto lócus é que o gene que codifica a permease possui pouca similaridade com o gene homólogo no lócus MAL1 dominante (Charron e Michels, 1988). Segundo estes autores, o alelo MAL1g deve ter sido originado através de um evento de rearranjo cromossômico. Neste evento, acredita-se que tenha ocorrido a remoção dos genes $M A L 11$ e $M A L 13$, presentes no lócus ancestral MAL1. Além da remoção, postula-se que tenha ocorrido a integração de uma outra região do genoma contendo um gene transportador (AGT1). Assim, o lócus resultante $(M A L 1 g)$, contém os genes estruturais $A G T 1$ e $M A L 12$, mas não contém o gene regulador MAL13.

Mais tarde, o gene que codifica a proteína transportadora no lócus $M A L 1 g$, bem como o seu produto, ou seja, a proteína em si, foram investigados em detalhes por Han et al. (1995). Descrito inicialmente como um transportador de maltose, verificou-se que este gene codifica uma permease com capacidade de transporte para diversos alfa-glicosideos, e assim, atribuiu-se a ele o nome AGT1 ("alpha-g/ucoside transporter"). Por apresentar cerca de $25 \%$ de identidade aos demais membros da superfamília de transportadores de açúcares (Nelissen et al., 1997; Silverman 1991), a proteína Agt1p foi incluída nesta categoria de transportadores (família TDM, "twelve transmembrane domain"). Dentre os demais membros, a maior identidade e similaridade é encontrada com a proteína Mal61p, o transportador de maltose codificado pelo gene $M A L 61$, sendo tais parâmetros de 57 e 75 \%, respectivamente (Han et al., 1995). Conforme descrito por Stambuk et al. (2000) e Stambuk e Araújo (2001), a permease Agt1p é um transportador de alta afinidade para a sacarose ( $K_{\mathrm{m}}$ $\sim 8 \mathrm{mM})$ e para a trealose $\left(K_{\mathrm{m}} \sim 7 \mathrm{mM}\right)$, e de menor afinidade para a maltose $\left(K_{\mathrm{m}} \sim 18 \mathrm{mM}\right)$, maltotriose $\left(K_{\mathrm{m}} \sim 18 \mathrm{mM}\right)$ e alfa-metil-glicosídeo $\left(K_{\mathrm{m}} \sim 34 \mathrm{mM}\right)$. Por outro lado, os transportadores Malx1p (mais especificamente Mal11p, Mal21p e Mal61p) possuem alta afinidade para a maltose [ambos com $K_{\mathrm{m}} \sim 5 \mathrm{mM}$; Cheng e Michels (1991); Stambuk e Araújo (2001)], enquanto que Mal21p transporta a sacarose com baixa afinidade ( $\left.K_{\mathrm{m}} \sim 120 \mathrm{mM}\right)$, segundo Stambuk et al. (2000).

Recentemente, duas novas permeases, capazes de transportar alfa-glicosídeos com alta afinidade, foram caracterizadas (Day et al., 2002). A seus genes, atribuiu-se o nome de MPH2 e MPH3 ("maltose permease homologue"), sendo que estão localizadas nos cromossomos IV e X (na linhagem S. cerevisiae S288C), respectivamente. As duas permeases são idênticas entre si, e compartilham $76 \%$ de identidade com as permeases Mal31p e 
Mal61p, e 53\% com a permease Agt1p (comparações realizadas com a seqüência de aminoácidos das permeases). Adicionalmente, têm a sua atividade mediada pela proteína reguladora Malx3p, como nas demais permeases desta família, porém apresentando apenas um sítio de ligação para a maltose, ao invés dos três sítios característicos das demais permeases (Ni e Needleman, 1990). Segundo os autores, em termos de especificidade pelo substrato, as duas permeases situam-se num nível intermediário em relação às permeases Mal31p e Mal61p, mais específicas para maltose, e a Agt1p, com um amplo espectro para alfa-glicosídeos. No entanto, não foi reportado no referido trabalho se tais permeases são capazes de transportar a sacarose, como no caso da permease Agt1p (Stambuk et al., 2000).

O outro gene estrutural deste lócus, $M A L \times 2$, codifica uma alfa-glicosidase (maltase). Trata-se de uma enzima citoplasmática, que possui pH ótimo em torno de 7 e é capaz de hidrolisar a ligação alfa-glicosídica, presente na maltose, na maltotriose, e na turanose, bem como na sacarose (Needleman, 1991; Zastrow et al., 2001). No entanto vale ressaltar que, como a sacarose é um dissacarídeo formado por uma molécula de glicose ligada a uma de frutose, através de uma ligação glicosídica de conformação glicose- $\alpha 1-\beta 2$-frutose, esta pode sofrer a ação tanto de hidrolases capazes de clivar a ligação alfa-glicosídica, quanto de hidrolases capazes de clivar a ligação beta-glicosídica, sendo este último o caso da enzima invertase.

\subsubsection{Regulação gênica dos loci MAL}

A regulação gênica dos loci MAL é mediada pela proteína Malx3p. No entanto, o mecanismo de regulação/ação da Malx3p é complexo e ainda não inteiramente compreendido. Os 3 sítios de ligação da proteína reguladora (sítios 1, 2 e 3) são distintos entre si tanto na estrutura como em suas seqüências (Figura 2.2). Os dois sítios (1 e 2) localizados entre os genes $M A L x 1$ e $M A L x 2$, bem como a região compreendida entre os

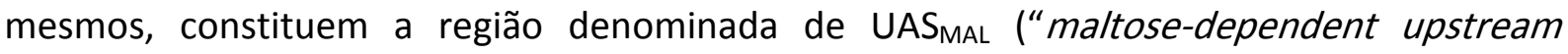
activating sequence'), a qual é o sítio de ligação da proteína reguladora na presença de maltose (Figura 2.2). Apesar desta região promotora ser bi-direcional, é possível que ela regule independentemente os genes $M A L x 1$ e $M A L x 2$ (Needleman, 1991). Adicionalmente, muitos outros genes parecem interferir na indução por maltose (SSN6, CYC9, HEX1, HEX2, 
MALX, MALY, SNF1) (Needleman, 1991). No caso específico da permease Agt1p, para o transporte de sacarose, esta permease parece ser induzida mais fortemente por alfa-metilglicosídeo e por maltose, ao passo que é insensível à indução pela trealose (Stambuk et al., 1999). Este mesmo trabalho aponta que o dissacarídeo transportado preferencialmente por esta permease é a trealose seguido da sacarose.

Por outro lado, a presença de glicose exerce um efeito repressor na expressão dos genes MAL. Tal efeito é mediado pelas proteínas Mig1p, Hxk2p, e Grr1p, sendo que o

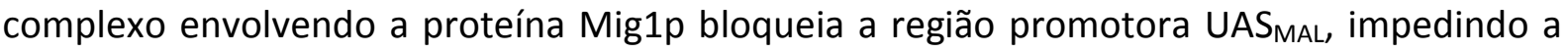
indução pela proteína reguladora (Hu et al., 1995; Needleman, 1991). Adicionalmente, sabese que a glicose, bem como análogos não-metabolizáveis, como por exemplo a 2-deoxi-Dglicose, podem desencadear a inativação dos transportadores, por um mecanismo de fosforilação, endocitose e degração/proteólise vacuolar dos mesmos, conhecido como inativação catabólica ou inativação induzida por glicose (Brondijk et al., 1998; Medintz et al., 1996; Riballo et al., 1995), a qual depende fortemente das condições de cultivo, e parece estar associada a um mecanismo de ubiquitinação (Lucero e Lagunas, 1997).

De uma forma geral, o mecanismo de repressão dos genes $M A L$ pela glicose pode ocorrer por duas maneiras: pela via de repressão catabólica (ou também conhecida por via de repressão por glicose), e pela via Ras/cAMP/proteína-quinase A (PKA). A primeira leva à repressão da transcrição dos genes $M A L$, enquanto a segunda parece resultar na inativação catabólica das permeases MAL (Brondijk et al., 1998; Verstrepen et al., 2004). No contexto industrial, a ativação de tais vias pode trazer prejuízos na produtividade e na velocidade da fermentação, pois a presença de glicose em mostos industriais provoca repressão na assimilação (transporte) e no metabolismo de açúcares como a maltose e a maltotriose, e possivelmente sacarose. De fato, a expressão de muitos genes responsáveis pela síntese de transportadores de maltose, bem como de maltases, parece ser reprimida permanentemente após o cultivo prolongado (adaptação) em meio contendo glicose como fonte de carbono (Kuthan et al., 2003). 


\subsubsection{Regulação gênica dos loci SUC}

Estudos mostram que a regulação do gene SUC2 é mediada por mecanismos transcricionais e pós-transcricionais. O primeiro mecanismo é decorrente da repressão da transcrição pela glicose (repressão por glicose). O segundo mecanismo envolve a degradação do mRNA ("turnover"), a qual também é induzida por glicose (Cereghino e Scheffler, 1996). Postula-se que a região promotora do transcrito menor (invertase intracelular) não responde à repressão por glicose, ao passo que a região promotora do outro transcrito maior (invertase extracelular) é regulada pela glicose e determinadas proteínas (Carlson e Botstein, 1982). Sabe-se que várias proteínas, como Grr1p, Reg1p, Hxt2p, Glc7p, Mig1p, Ssn6p e Tup1p estão envolvidas nesta via de regulação (Carlson e Botstein, 1982; Gancedo, 1992). Outras proteínas, como Snf1p e Snf4p, são requeridas para que ocorra a desrepressão do gene $S U C 2$, e mutantes snf1 não são capazes de sintetizar o transcrito referente à invertase extracelular, mesmo na ausência da repressão por glicose (Carlson e Botstein, 1982). Um dos componentes principais deste mecanismo regulatório é a proteína Mig1p (gene MIG1 "Multicopy Inhibitor of GAL gene expression"; Nehlin e Ronne, 1990), que se liga à região promotora do gene $S U C 2$, reprimindo sua transcrição sob altos níveis de glicose.

Se, por um lado, altos teores de glicose reprimem a expressão do gene SUC2 (invertase extracelular), foi demonstrado por Ozcan et al. (1997) que este mesmo gene tem a sua máxima expressão quando na presença de baixos níveis de glicose ou frutose $[0,1$ $0,005 \%(p / v)]$, produtos resultantes da clivagem da sacarose. Adicionalmente, a indução a baixos níveis de glicose parece ocorrer pelo relaxamento de um mecanismo de repressão, do qual uma região à montante do gene SUC2 (URS $S_{\text {SUC }}$ ), bem como o gene SNF3, são componentes essenciais. Estes autores observaram que a atividade de invertase extracelular é de 5 a 10 vezes maior em células crescendo na presença de baixos teores de glicose [0,1\% $(p / v)]$, quando comparada à atividade em células crescendo em glicerol. Desta forma, se existir excesso de glicose num meio de cultura contendo sacarose, células de $S$. cerevisiae terão a expressão do gene SUC2 reprimida, consumindo preferencialmente a glicose e poupando a sacarose para instantes futuros. É sugerido por Ozcan et al. (1997) que estes mecanismos de repressão e indução por glicose, aparentemente antagônicos, servem para ajustar os níveis de invertase no meio de crescimento, garantindo uma utilização eficiente das fontes de carbono disponíveis. 
Finalmente, a regulação do gene SUC2 é, de certa forma, semelhante à regulação dos genes dos transportadores de glicose HXT2 e HXT4. Os três são reprimidos por altos níveis de glicose e induzidos por baixos níveis deste açúcar. No entanto, diferentemente dos dois últimos, a proteína repressora Rgt1p parece não exercer influência sobre a expressão do gene SUC2, enquanto que a proteína Snf3p promove a indução a baixos níveis de glicose, de forma similar aos genes HXT2 e HXT4 (Ozcan et al., 1997).

\subsection{Fisiologia quantitativa de $S$. cerevisiae durante o crescimento em sacarose ou em misturas de glicose e frutose}

São poucos os trabalhos publicados na literatura sobre cultivos de $S$. cerevisiae em meio sintético contendo sacarose como fonte de carbono. Ainda mais marcante é a ausência completa de dados experimentais quantitativos, obtidos durante o crescimento de $S$. cerevisiae limitado por sacarose, em anaerobiose. Além disto, os poucos trabalhos existentes muitas vezes utilizaram células de $S$. cerevisiae adaptadas em sacarose por cerca de 250 gerações (Barford et al., 1995; Orlowsky e Barford, 1991), o que pode comprometer a interpretação dos resultados, uma vez que o fenótipo original pode ter sido alterado por mecanismos adaptativos e/ou evolutivos (Ferea et al., 1999). Abaixo apresentamos uma compilação de dados obtidos da literatura sobre cultivos de $S$. cerevisiae em sacarose, ou numa mistura de glicose e frutose, em meio sintético totalmente definido (Tabela 2.1). 
Tabela 2.1 - Principais parâmetros fisiológicos de S. cerevisiae (linhagem 248 UNSW 703100) durante o crescimento em sacarose ou em misturas de glicose e frutose, sob regime de aerobiose.

\begin{tabular}{|c|c|c|c|c|c|c|c|c|}
\hline Modo de cultivo & $\mu$ ou $D\left(\mathrm{~h}^{-1}\right)$ & $\begin{array}{c}q_{\mathrm{s}} \\
{\left[\mathrm{mmol} \text { GLC eq. }(\mathrm{g} \mathrm{dw} \cdot \mathrm{h})^{-1}\right]}\end{array}$ & $\begin{array}{c}Y_{x / s} \\
\left(g d w \cdot g^{-1}\right)\end{array}$ & $\begin{array}{c}Y_{\text {ETH/S }} \\
\left(\mathrm{g} \text { ETH.g } g^{-1}\right)\end{array}$ & $\begin{array}{c}q_{\mathrm{cO} 2} \\
{\left[\mathrm{mmol} .(\mathrm{g} \mathrm{dw} . h)^{-1}\right]}\end{array}$ & $\begin{array}{c}902 \\
{\left[\mathrm{mmol} .(\mathrm{g} \mathrm{dw} . \mathrm{h})^{-1}\right]}\end{array}$ & Fonte de Carbono & Referências \\
\hline Batelada $^{a}$ & 0,45 & 17 & 0,15 & $n d^{b}$ & nd & nd & $\begin{array}{c}\text { Glicose }(5 \mathrm{~g} / \mathrm{L})+ \\
\text { Frutose }(5 \mathrm{~g} / \mathrm{L})\end{array}$ & $\begin{array}{l}\text { Orlowsky and } \\
\text { Barford, } 1991\end{array}$ \\
\hline Batelada $^{a}$ & 0,55 & 19 & 0,16 & nd & nd & nd & Sacarose (10 g/L) & $\begin{array}{l}\text { Orlowsky and } \\
\text { Barford, } 1991\end{array}$ \\
\hline Contínuo ${ }^{\mathrm{a}, \mathrm{c}}$ & 0,55 & 22 & 0,14 & 0,38 & nd & nd & $\begin{array}{l}\text { Glicose }(5 \mathrm{~g} / \mathrm{L})+ \\
\text { Frutose }(5 \mathrm{~g} / \mathrm{L})\end{array}$ & $\begin{array}{l}\text { Orlowsky and } \\
\text { Barford, } 1991\end{array}$ \\
\hline Contínuo ${ }^{a, c}$ & 0,55 & 23 & 0,17 & 0,36 & nd & nd & Sacarose (10 g/L) & $\begin{array}{l}\text { Orlowsky and } \\
\text { Barford, } 1991\end{array}$ \\
\hline Contínuo $^{c}$ & 0,09 & 1,5 & 0,55 & 0 & 2,2 & 2,0 & $\begin{array}{l}\text { Glicose }(10 \mathrm{~g} / \mathrm{L})+ \\
\text { Frutose }(10 \mathrm{~g} / \mathrm{L})\end{array}$ & $\begin{array}{l}\text { Johnston and } \\
\text { Barford, } 1991\end{array}$ \\
\hline Contínuo $^{c}$ & 0,23 & 2,5 & 0,55 & 0 & 4,9 & 4,7 & $\begin{array}{l}\text { Glicose }(10 \mathrm{~g} / \mathrm{L})+ \\
\text { Frutose }(10 \mathrm{~g} / \mathrm{L})\end{array}$ & $\begin{array}{l}\text { Johnston and } \\
\text { Barford, } 1991\end{array}$ \\
\hline Contínuo $^{c}$ & 0,31 & 9 & 0,20 & 0,35 & 22,3 & 4,0 & $\begin{array}{l}\text { Glicose }(10 \mathrm{~g} / \mathrm{L})+ \\
\text { Frutose }(10 \mathrm{~g} / \mathrm{L})\end{array}$ & $\begin{array}{l}\text { Johnston and } \\
\text { Barford, } 1991\end{array}$ \\
\hline Contínuo & 0,41 & 17 & 0,13 & 0,41 & 32,4 & 4,5 & $\begin{array}{l}\text { Glicose }(10 \mathrm{~g} / \mathrm{L})+ \\
\text { Frutose }(10 \mathrm{~g} / \mathrm{L})\end{array}$ & $\begin{array}{l}\text { Johnston and } \\
\text { Barford, } 1991\end{array}$ \\
\hline Contínuo & 0,41 & 14 & 0,16 & 0,31 & nd & nd & $\begin{array}{l}\text { Glicose }(5 \mathrm{~g} / \mathrm{L})+ \\
\text { Frutose }(5 \mathrm{~g} / \mathrm{L})\end{array}$ & $\begin{array}{l}\text { Johnston and } \\
\text { Barford, } 1991\end{array}$ \\
\hline Contínuo $^{c}$ & 0,09 & nd & nd & 0 & 2 & 2 & Sacarose (10 g/L) & $\begin{array}{l}\text { Barford et al,, } \\
1995\end{array}$ \\
\hline Contínuo $^{c}$ & 0,17 & nd & nd & 0 & 4 & 4 & Sacarose (10 g/L) & $\begin{array}{l}\text { Barford et al,, } \\
1995\end{array}$ \\
\hline Contínuo & 0,10 & 1,2 & 0,54 & 0 & 2,2 & 2,5 & Sacarose (10 g/L) & Basso et al,, 2010 \\
\hline
\end{tabular}

(a) As células foram previamente adaptadas em sacarose por cerca de 250 gerações antes do experimento.

(b) Não determinado.

(c) Parâmetros estimados a partir dos gráficos publicados. 
Já foi demonstrado diversas vezes que as velocidades específicas máximas de crescimento e de consumo de açúcares sofrem aumento, quando células de levedura são previamente adaptadas ao substrato em estudo. Orlowsky e Barford (1991) foram os primeiros a chamar a atenção para este fenômeno em cultivos com sacarose. Em seu estudo pioneiro sobre a fisiologia de $S$. cerevisiae, utilizando meio de cultivo totalmente definido, estes autores reportam os primeiros dados da fisiologia quantitativa de leveduras na utilização da sacarose. Em cultivos em modo batelada, sob regime de aerobiose e com células adaptadas à sacarose por 250 gerações (em transferências seriadas), eles reportaram dados de $\mu_{\max }, Y_{x / s}$ e $q_{s}: 0,55 \mathrm{~h}^{-1} ; 0,16 \mathrm{~g} \mathrm{DW} \cdot \mathrm{g}^{-1}$ e 19 mmol.(g DW.h $)^{-1}$, respectivamente. Além disto, constataram que os mesmos parâmetros foram todos menores (de 5 a 10 \% em relação aos valores obtidos em sacarose) em cultivos com células adaptadas à respectiva fonte de carbono, quando a mesma foi glicose, frutose, ou uma mistura equimolar de glicose e frutose (Tabela 2.1). Segundo os autores, os resultados indicam, de forma indireta, que o transporte da sacarose ocorrendo simultaneamente à capatação dos monossacarídeos foi a causa do aumento no $\mu_{\max }$ de $0,45 \mathrm{~h}^{-1}$ em glicose + frutose, para 0,55 $\mathrm{h}^{-1}$ em sacarose. Corroborando esta hipótese, Barford et al. (1995), em cultivos contínuos e utilizando células adaptadas por mais de 200 gerações, verificaram que a taxa de diluição máxima em sacarose $\left(D=0,56 \mathrm{~h}^{-1}\right)$ foi significativamente maior do que a obtida em frutose $\left(D=0,49 \mathrm{~h}^{-1}\right)($ Tabela 2.1).

Em cultivos contínuos aeróbicos e limitados simultaneamente por glicose e frutose, foi observado que a transição do metabolismo respiratório para o respiro-fermentativo (evidenciado pela presença de etanol no meio de cultivo) ocorreu em algum valor de vazão específica $(D)$ entre 0,23 e 0,31 $\mathrm{h}^{-1}$ (Johnston e Barford, 1991) (Tabela 2.1). No caso de cultivos aeróbicos limitados por sacarose, a mesma transição ocorreu para $D$ entre 0,27 e 0,33 $\mathrm{h}^{-1}$ (Barford et al., 1995). Um fato intrigante foi observado nos cultivos contínuos limitados por misturas equimolares de glicose e frutose. Johnston e Barford (1991), observaram que ambos os açúcares foram consumidos na mesma velocidade e por completo à vazões específicas menores do que $0,40 \mathrm{~h}^{-1}$. No entanto, acima deste valor, o consumo de ambas as fontes de carbono foi incompleto. Este consumo incompleto parece ter sido relacionado à concentração de açucares na alimentação, sendo que foi observado a $20 \mathrm{~g} / \mathrm{L}$ e não a $10 \mathrm{~g} / \mathrm{L}$. 
Apesar de descrito há algum tempo (Santos et al., 1982), acreditava-se que o transporte direto de sacarose contribuía muito pouco para a utilização deste açúcar por $S$. cerevisiae. No entanto, em vista dos trabalhos apresentados acima, parece que este mecanismo pode ter contribuição significativa ao metabolismo de sacarose, caso as células sejam previamente adaptadas a ela por várias gerações ( 200-250) (Mwesigye e Barford, 1996). 


\section{OBJETIVOS}

O objetivo geral do presente trabalho foi estudar as alterações fisiológicas na levedura Saccharomyces cerevisiae, decorrentes de modificações na topologia e na energética do metabolismo da sacarose nesta levedura. Estas modificações foram introduzidas tanto por engenharia metabólica (eliminação da atividade de invertase extracelular e superexpressão da atividade intracelular da enzima), como por engenharia evolutiva subsequente (melhoria do transporte ativo da sacarose).

Os objetivos específicos foram os seguintes:

3.1 Estudar os efeitos da limitação por uracila na fisiologia quantitativa de linhagens de $S$. cerevisiae auxotróficas para este nutriente, durante cultivos em quimiostato;

3.2 Comparar os parâmetros fisiológicos e o transcriptoma de uma linhagem da levedura $S$. cerevisiae que não apresenta atividade de invertase extracelular e que superexpressa atividade de invertase intracelular (denominada iSUC2), com os parâmetros correspondentes de uma linhagem referência (SUC2), durante o estado-estacionário de cultivos contínuos limitados por sacarose;

3.3 Comparar os parâmetros fisiológicos das linhagens iSUC2 e SUC2 (descritas acima), durante o crescimento exponencial em cultivos descontínuos;

3.4 Investigar os efeitos da deleção do gene AGT1, que codifica a principal proteína transportadora de sacarose, nas linhagens iSUC2 e $S U C 2$, durante o crescimento exponencial em cultivos descontínuos;

3.5 Alterar as características do transporte da sacarose na linhagem iSUC2 pelo uso da engenharia evolutiva; 
3.6 Avaliar a fisiologia e o transcriptoma da linhagem iSUC2 evoluída, durante cultivos contínuos e descontínuos em sacarose;

3.7. Tentar verificar quais alterações genéticas ocorreram durante o processo de evolução em quimiostato e que foram responsáveis pelo fenótipo melhorado da linhagem iSUC2 evoluída, em relação à linhagem iSUC2. 


\section{MATERIAIS E MÉTODOS}

\subsection{Linhagens de levedura e preservação}

As linhagens utilizadas para o desenvolvimento deste projeto são apresentadas na Tabela 4.1. A família de leveduras "CEN.PK" foi escolhida para o desenvolvimento deste projeto pois tratam-se de linhagens laboratoriais referência para estudos fisiológicos e de genômica funcional (Van Dijken et al., 2000). Duas destas linhagens (CEN.PK113-5D e CEN.PK113-7D) foram gentilmente cedidas pelo Dr. Peter Kötter (Institut für Mikrobiologie der Johan Wolfgang Goethe-Universität, Alemanha). A linhagem BSY021-34B (iSUC2 ura-), incapaz de hidrolisar sacarose no ambiente extracelular e que superexpressa a invertase no ambiente intracelular, foi construída pelo grupo do Prof. Dr. Boris U. Stambuk (Universidade Federal de Santa Catarina, Brasil) e gentilmente cedida por ele, que é um colaborador neste projeto, juntamente com seu aluno de doutoramento, Marcelo Goulart Dário.

As linhagens foram estocadas no Laboratório de Engenharia Bioquímica da Universidade de São Paulo (LEB/USP) e no Laboratório de Microbiologia Industrial da TU Delft (LMI/TU Delft), sob a forma de cultura-estoque em meio YPD (extrato de levedura, 10 g. $\mathrm{L}^{-1}$, peptona, $20 \mathrm{~g} . \mathrm{L}^{-1}$, glicose, $\left.20 \mathrm{~g} . \mathrm{L}^{-1}\right)$, contendo $20 \%(\mathrm{p} / \mathrm{v})$ de glicerol, a $-80{ }^{\circ} \mathrm{C}$. Para a obtenção dos estoques, primeiramente cultivou-se cada linhagem descrita na Tabela 4.1 em frascos Erlenmeyer de $500 \mathrm{~mL}$ contendo $100 \mathrm{~mL}$ de meio YPD em incubador rotativo (marca New Brunswick, modelo C24, Edison, New Jersey, USA) a $30{ }^{\circ} \mathrm{C}$ e $200 \mathrm{rpm}$. Após cerca de 24 $\mathrm{h}$ de crescimento, adicionou-se à suspensão volume suficiente de glicerol estéril para resultar numa concentração final de $20 \%(p / v)$. Em seguida, alíquotas de $1 \mathrm{~mL}$ foram distribuídas em criotubos estéreis, os quais foram congelados à temperatura de $-80^{\circ} \mathrm{C}$. Estes estoques congelados foram empregados para se gerar o inóculo para os cultivos em quimiostato, bem como para os cultivos em frasco agitado e para as bateladas repetidas (cultivos descontínuos). 
Tabela 4.1 - Linhagens utilizadas neste projeto.

\begin{tabular}{|c|c|c|c|}
\hline Linhagem & Nomenclatura* & Genótipo relevante & Fonte \\
\hline CEN.PK113-7D & SUC2 & $\begin{array}{l}\text { MATa mal13 AGT1 MAL12 MAL2-8c } \\
\text { URA3 SUC2 }\end{array}$ & Peter Kötter \\
\hline CEN.PK113-5D & SUC2 ura- & $\begin{array}{l}\text { MATa mal13 AGT1 MAL12 MAL2-8c } \\
\text { ura3-52 SUC2 }\end{array}$ & Peter Kötter \\
\hline BSY021-34B & iSUC2 ura- & $\begin{array}{l}\text { MATa mal13 AGT1 MAL12 MAL2-8c } \\
\text { ura3-52 trip1-289 TRP1-pADH1::iSUC2 }\end{array}$ & Boris Stambuk \\
\hline IMI-056 & iSUC2 & $\begin{array}{l}\text { Isogênica à BSY021-34B, mas ura3- } \\
52:: U R A 3\end{array}$ & Este trabalho \\
\hline IMK-305 & isuC2 $\Delta a g t 1$ & Isogênica à IMI-056, mas agt1ム::KanMX & Este trabalho \\
\hline IMK-308 & suC2 $\Delta a g t 1$ & $\begin{array}{l}\text { Isogênica à CEN.PK113-7D, mas } \\
\text { agt1 } \Delta: \text { KanMX }\end{array}$ & Este trabalho \\
\hline IMM-007 & iSUC2 evoluída & Evoluída a partir da linhagem IMI-056 & Este trabalho \\
\hline IMM-008 & iSUC2 evoluída $\Delta a g t 1$ & Isogênica à IMM-007, mas agt1ه::kanMX & Este trabalho \\
\hline IMM-009 & isUC2 evoluída $\Delta / \Delta a g t 1$ & $\begin{array}{l}\text { Isogênica à IMM-008, mas agt1 } 14: \text { loxP- } \\
\text { hphN-loxP }\end{array}$ & Este trabalho \\
\hline IMI-066 & iSUC2 $\mathrm{P}_{\text {TPII }} M A L 13$ & $\begin{array}{l}\text { Isogênica à IMI-056, mas } \mathrm{P}_{M A L 13}: \text { :loXP- } \\
K a n M X-l o X P-P_{T P I 1}\end{array}$ & Este trabalho \\
\hline IMI-067 & $\mathrm{i} S U C 2 \mathrm{P}_{\text {TDH3 }}-A G T 1$ & $\begin{array}{l}\text { Isogênica à IMI-056, mas URA3-P }{ }_{T D H 3^{-}} \\
\text {AGT1-T }{ }_{C Y C 1}: \text { ura3-52 }\end{array}$ & Este trabalho \\
\hline IMM-010 & iSUC2 evoluída $\Delta m a / 13$ & $\begin{array}{l}\text { Isogênica à IMM-007, mas mal134::loxP- } \\
\text { hphN-loxP }\end{array}$ & Este trabalho \\
\hline
\end{tabular}

*Esta nomenclatura será empregada ao longo do texto para identificar as linhagens.

\subsection{Meios de cultivo}

Neste trabalho foram utilizados 3 meios de cultivo. 1) Meio YP, contendo 10 g. L $^{-1}$ de extrato de levedura, 20 g. $\mathrm{L}^{-1}$ de bacto-peptona. 2) Meio sintético definido cuja composição é a descrita por Verduyn et al. (1992). Este meio contém, por litro: $\left(\mathrm{NH}_{4}\right)_{2} \mathrm{SO}_{4}, 5 \mathrm{~g} ; \mathrm{KH}_{2} \mathrm{PO}_{4}, 3 \mathrm{~g}$; $\mathrm{MgSO}_{4} .7 \mathrm{H}_{2} \mathrm{O}, 0,5 \mathrm{~g}$. Além desses nutrientes, o meio é suplementando com os seguintes elementos traço para conter, por litro: EDTA, $15 \mathrm{mg}$; $\mathrm{ZnSO}_{4} .7 \mathrm{H}_{2} \mathrm{O}, 4,5 \mathrm{mg}$; $\mathrm{CoCl}_{2} \cdot 6 \mathrm{H}_{2} \mathrm{O}, 0,3$ $\mathrm{mg} ; \mathrm{MnCl}_{2} \cdot 4 \mathrm{H}_{2} \mathrm{O}, 0,84 \mathrm{mg} ; \mathrm{CuSO}_{4} \cdot 5 \mathrm{H}_{2} \mathrm{O}, 0,3 \mathrm{mg} ; \mathrm{CaCl}_{2} \cdot 2 \mathrm{H}_{2} \mathrm{O}, 4,5 \mathrm{mg} ; \mathrm{FeSO}_{4} \cdot 7 \mathrm{H}_{2} \mathrm{O}, 3 \mathrm{mg}$; $\mathrm{NaMoO}_{4} \cdot 2 \mathrm{H}_{2} \mathrm{O}, 0,4 \mathrm{mg} ; \mathrm{H}_{3} \mathrm{BO}_{3}, 1 \mathrm{mg} ; \mathrm{KI}, 0,1 \mathrm{mg}$. Adicionou-se também ao meio as seguintes vitaminas para conter, por litro: biotina, 0,05 mg; pantotenato de cálcio, $1 \mathrm{mg}$; ácido nicotínico, $1 \mathrm{mg}$; inositol, $25 \mathrm{mg}$; tiamina- $\mathrm{HCl}, 1 \mathrm{mg}$; piridoxina- $\mathrm{HCl}, 1 \mathrm{mg}$; e ácido paraaminobenzóico, 0,2 mg. 3) Meio sintético definido com uréia (Luttik et al., 2000), onde a única diferença deste meio com o anterior é que este contém, por litro, uréia ( $2,3 \mathrm{~g})$ ao invés de $\left(\mathrm{NH}_{4}\right)_{2} \mathrm{SO}_{4}$, além de ser acrescido de $\mathrm{K}_{2} \mathrm{SO}_{4}(6,6 \mathrm{~g})$. Cabe ressaltar que as quantidades de nitrogênio e enxofre são as mesmas nos dois meios. Por fim, todos os 3 meios foram acrescidos da fonte de carbono em estudo (glicose ou sacarose). 
Para o preparo dos meios 2 e 3, as soluções de elementos traço, de vitaminas e de uréia foram preparadas separadamente e esterilizadas por filtração com membrana de 0,22 $\mu \mathrm{m}$ (marca Millipore, Billerica, MA, USA). Os demais componentes foram esterilizados por autoclavagem a $120{ }^{\circ} \mathrm{C}$ durante $15 \mathrm{~min}$. Em relação às fontes de carbono, estas foram adicionadas após a esterilização dos outros componentes, sendo que a solução de sacarose foi esterilizada por filtração com membrana de 0,22 $\mu \mathrm{m}$ (Millipore) para se evitar hidrólise do dissacarídeo, enquanto a solução de glicose foi esterilizada por autoclavagem a $110{ }^{\circ} \mathrm{C}$ durante $20 \mathrm{~min}$. Todas as soluções foram misturadas sob condições assépticas.

No caso dos quimiostatos e nas bateladas repetidas (SBR) em anaerobiose total, o meio foi suplementado com ergosterol e Tween 80 (10 e $420 \mathrm{mg} . \mathrm{L}^{-1}$, respectivamente). Nos experimentos com as linhagens auxotróficas para a uracila, o meio foi suplementado com

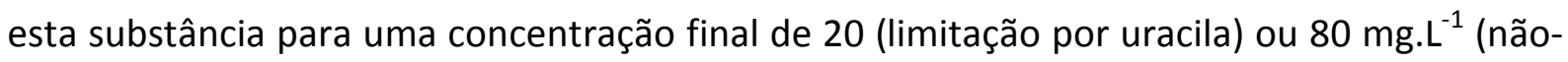
limitação por uracila), conforme indicado.

Para a confecção de meios seletivos adicionou-se $200 \mathrm{mg} \cdot \mathrm{L}^{-1}$ de Geneticina-G418 (Sigma, St. Louis, MO, USA) ou $100 \mathrm{mg} \cdot \mathrm{L}^{-1}$ de Higromicina (Sigma). Para a preparação de meios solidificados, acresentou-se $20 \mathrm{~g} . \mathrm{L}^{-1}$ de bacto-ágar.

O cultivo de Escherichia coli, destinado à multiplicação e ao isolamento de plasmídeos, foi realizado a $30{ }^{\circ} \mathrm{C}$ em meio Luria-Bertani. Quando necessário, $100 \mathrm{mg} \cdot \mathrm{L}^{-1} \mathrm{de}$ Ampicilina (Sigma) foram adicionados.

\subsection{Condições de cultivo}

\subsubsection{Cultivo em frasco agitado}

Nestes ensaios foram utilizados dois tipos de meios: 1) YP acrescido da fonte de carbono; e 2) meio sintético definido com uréia, empregado para se evitar uma elevada acidificação do meio. Quando necessário, foram adicionados $80 \mathrm{mg} \cdot \mathrm{L}^{-1}$ de uracila ao meio sintético.

O inóculo para o cultivo em frasco agitado foi obtido da seguinte maneira: parte do conteúdo de um tubo da cultura-estoque da linhagem a ser estudada foi transferida para uma placa de Petri contendo meio YPD-ágar $2 \%(p / v)$, com auxílio de uma alça de platina, 
usando a técnica da semeadura por esgotamento. A placa foi então incubada em estufa a 30 ${ }^{\circ} \mathrm{C}$. Após cerca de $24 \mathrm{~h}$, células de uma colônia isolada foram transferidas para um frasco Erlenmeyer de $500 \mathrm{~mL}$ contendo $100 \mathrm{~mL}$ de meio sintético definido com uréia (Luttik et al., 2000) ou meio rico (conforme o experimento) e colocado em incubador rotativo a $30{ }^{\circ} \mathrm{C} \mathrm{e}$ 200 rpm. Após um cultivo "overnight", a absorbância foi medida a $600 \mathrm{~nm}\left(\mathrm{Abs}_{600}\right)$ e o volume de inóculo para o cultivo em frasco agitado foi calculado de forma a se iniciar o cultivo com $\mathrm{Abs}_{600}$ de 0,1 . No momento da transferência do inóculo para os frascos agitados, as células encontravam-se na fase exponencial de crescimento.

Os cultivos em frasco agitado foram conduzidos em Erlenmeyer chicanados de $\mathbf{5 0 0}$ $\mathrm{mL}$ contendo $100 \mathrm{~mL}$ de meio sintético definido com uréia, acrescido da fonte de carbono. Os frascos foram incubados a $30{ }^{\circ} \mathrm{C}$ e $200 \mathrm{rpm}$. O crescimento celular foi acompanhado pela medida da $\mathrm{Abs}_{600}$, após retirada de amostras da cultura em tempos pré-determinados (normalmente de hora em hora). Parte dessas amostras foi filtrada por pressão positiva usando filtros descartáveis e utilizada para a quantificação dos açúcares e outros metabólitos (etanol, glicerol e ácidos orgânicos).

\subsubsection{Cultivos em quimiostato}

O inóculo para os cultivos em quimiostato foi obtido conforme descrito acima (item 4.3.1), porém empregando-se meio mineral definido conforme Verduyn et al. (1992), com sulfato de amônio, em vez de uréia, como fonte de nitrogênio. Após um cultivo "overnight", a absorbância foi medida a $600 \mathrm{~nm}$ e o volume de inóculo para o fermentador foi calculado de forma a se iniciar o cultivo com $\mathrm{Abs}_{600}$ de 0,1.

As linhagens de $S$. cerevisiae estudadas foram cultivadas em regime de quimiostato a uma vazão específica de $0,10 \mathrm{~h}^{-1}$ empregando-se biorreatores de bancada (marca New Brunswick, modelo BIOFLO III, Edison, New Jersey, USA), nos experimentos realizados no Laboratório de Engenharia Bioquímica da Universidade de São Paulo (LEB/USP), e biorreatores de bancada (marca Applikon, Schiedam, Holanda), nos cultivos realizados no Laboratório de Microbiologia Industrial da Delft University of Technology (LMI/TU Delft). Um esquema geral dos sistemas utilizados é apresentado na Figura 4.1. 
O meio de cultura utilizado foi o meio sintético definido (Verduyn et al. 1992), contendo glicose ou sacarose como única fonte de carbono (item 4.2). $\mathrm{O}$ pH dos cultivos foi mantido constante em 5,0 através da adição controlada de uma solução de $\mathrm{KOH} 2 \mathrm{M}$. A temperatura foi de $30{ }^{\circ} \mathrm{C}$ e a agitação mantida em $800 \mathrm{rpm}$. O condensador do gás de saída do fermentador foi mantido a $2{ }^{\circ} \mathrm{C}$, de forma a se minimizar a perda de etanol e outros metabólitos. Para o regime em quimiostato, que foi iniciado como um cultivo descontínuo, a adição e a retirada contínuas de meio passaram a ocorrer no momento de exaustão da fonte de carbono da etapa em batelada, o que correspondeu ao início na queda do sinal de \% de $\mathrm{CO}_{2}$ no gás de saída do reator. A adição de meio de cultura estéril ao fermentador foi realizada por meio de uma bomba peristáltica de precisão. A remoção de meio deu-se por uma bomba continuamente ligada e conectada a um dreno localizado à altura adequada no fermentador, no caso dos cultivos no LEB/USP, ou utilizando-se um sensor de nível eletrônico, no caso dos cultivos no LMI/TU Delft, de forma a sempre se manter um volume de trabalho de $1 \mathrm{~L}$ em ambos os casos.

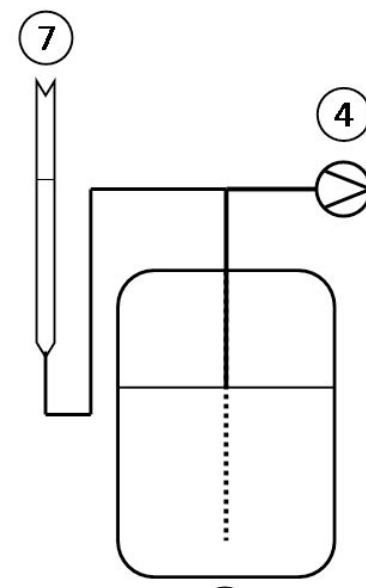

(1)

$(4)$

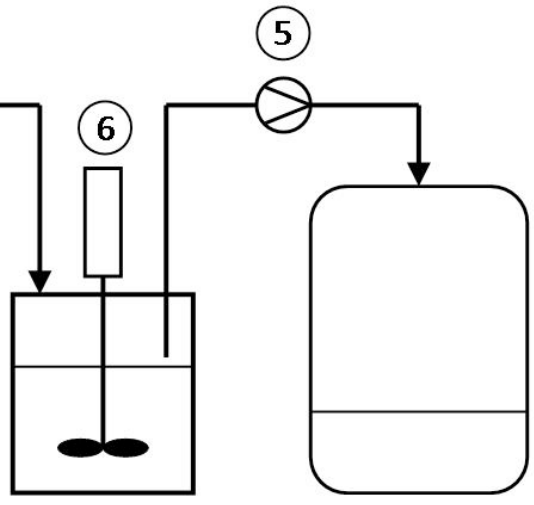

(2)

(3)

Figura 4.1 - Configuração geral do sistema de biorreatores para cultivos contínuos, em regime de aerobiose e anaerobiose, empregado no presente estudo. 1) Frasco contendo meio de alimentação; 2) Biorreator de bancada; 3) Frasco para coleta do efluente. 4) Bomba peristáltica de alimentação de meio; 5) Bomba peristáltica de retirada de efluente (meio + células); 6) Sistema de agitação; 7) Sistema para medida da vazão de alimentação.

Nos cultivos em aerobiose, ar comprimido foi introduzido no reator a uma vazão de 0,5 L. $\mathrm{min}^{-1}$ por meio de um controlador de fluxo mássico (marca Brooks, modelo 5876, Hatfield, PA, USA). A concentração de oxigênio dissolvido foi monitorada de forma contínua por um eletrodo de oxigênio dissolvido (marca Mettler-Toledo, Columbus, OH, USA) e 
permaneceu acima de $60 \%$ da saturação com ar por todo o experimento, de modo a se garantir condições de plena aerobiose.

Para os cultivos em anaerobiose, os fermentadores foram equipados com mangueiras de Norprene (Cole-Parmer, Vernon Hills, Illinois, USA), para se evitar a entrada de oxigênio no sistema, e foram borbulhados com gás nitrogênio (pureza de 99,95\% no LEB/USP e de 99,995\% no LMI/TU Delft) a uma vazão 0,5 L. $\mathrm{min}^{-1}$. Nestes cultivos, o frasco de alimentação também foi borbulhado com o mesmo gás durante todo o experimento, a uma vazão de $50 \mathrm{~mL} \cdot \mathrm{min}^{-1}$, e também foi protegido da luz para se evitar degradação do ergosterol.

O estado estacionário foi definido como a situação em que ao menos 5 tempos de residência tivessem passado depois da última mudança nas condições de cultivo e em que tanto a concentração de biomassa como a velocidade específica de produção de $\mathrm{CO}_{2}$ no gás de saída do biorreator, tivessem permanecido constantes (variação menor do que 2\%) durante os dois últimos tempos de residência.

Nos experimentos de evolução, a linhagem iSUC2 foi cultivada de forma análoga aos quimiostatos em anaerobiose limitados por sacarose, porém estes cultivos foram prolongados até o momento em que se constatou redução do substrato residual (item 4.6) e aumento da capacidade de co-transporte de $\mathrm{H}^{+}$(item 4.10). Para tanto, amostras foram coletadas diariamente, sendo que ao final do cultivo (após cerca de 100 gerações) a suspensão de células amostrada do biorreator foi plaqueada em meio sólido YPD, e algumas colônias isoladas foram estocadas conforme o item 4.1.

\subsubsection{Cultivos em bateladas repetidas (SBR)}

Os cultivos em bateladas repetidas foram realizados no LMI/TU Delft, com reatores de bancada Applikon. O inóculo para tais cultivos foi obtido conforme descrito no item 4.3.1, porém empregando-se meio mineral definido conforme Verduyn et al. (1992), com sulfato de amônio. Após um cultivo "overnight", a absorbância foi medida a $600 \mathrm{~nm}$ e o volume de inóculo para o fermentador foi calculado de forma a se iniciar o cultivo com Abs $_{600}$ de 0,1.

As linhagens de $S$. cerevisiae estudadas foram cultivadas em regime de bateladas repetidas e o terceiro ciclo foi amostrado. O meio de cultura utilizado foi o meio sintético 
definido (Verduyn et al. 1992), contendo sacarose como única fonte de carbono (item 4.2). O $\mathrm{pH}$ dos cultivos foi mantido constante em 5,0 através da adição controlada de uma solução de $\mathrm{KOH} 2 \mathrm{M}$. A temperatura foi de $30{ }^{\circ} \mathrm{C}$ e a agitação mantida em $800 \mathrm{rpm}$. O condensador do gás de saída do fermentador foi mantido a $2{ }^{\circ} \mathrm{C}$, de forma a se minimizar a perda de etanol e outros metabólitos. Para o regime em bateladas repetidas, a retirada (cerca de $95 \%$ do volume do meio) e a adição de meio estéril passaram a ocorrer no momento da exaustão da fonte de carbono na etapa anterior, o que correspondeu ao início na queda do sinal de \% de $\mathrm{CO}_{2}$ no gás de saída do reator. Os reatores foram equipados com mangueiras de Norprene para se evitar a entrada de oxigênio (presente na atmosfera) no sistema, e foram borbulhados com gás nitrogênio (pureza de 99,995\%) a uma vazão de 0,5 L. $\min ^{-1}$.

\subsection{Determinação da fração molar de $\mathrm{O}_{2}$ e $\mathrm{CO}_{2}$ no gás de saída do biorreator}

Nos cultivos realizados no LEB/USP, os gases de saída do biorreator foram previamente secos pela passagem em recipiente com sílica, e analisados quanto às frações molares de $\mathrm{CO}_{2}$ e $\mathrm{O}_{2}$ por um analisador de gases. A determinação da fração molar de $\mathrm{O}_{2}$ no gás de saída foi realizada por um detector paramagnético (marca Beckman, modelo 755, Brea, CA, USA), enquanto que a fração molar de $\mathrm{CO}_{2}$ foi determinada com um detector na faixa do infravermelho (marca Fuji eletric, modelo 3300, Burlington, NJ, USA).

Nos cultivos realizados no LMI/TU Delft, os gases de saída do fermentador foram previamente secos através de um secador Perma Pure (PD-625-12P) e analisados quanto às frações molares de $\mathrm{CO}_{2}$ e $\mathrm{O}_{2}$ por um analisador de gases (marca Rosemound, modelo NGA 2000, Knoxville, TN, USA).

\subsection{Quantificação da concentração de metabólitos extraclulares e intracelulares}

Um determinado volume de amostra, após retirada do cultivo, foi imediatamente filtrado por pressão positiva em filtros de porosidade 0,22 $\mu \mathrm{m}$ (Millipore) e o filtrado utilizado nas determinações. Glicose, etanol, glicerol, acetato, succinato e piruvato foram separados numa coluna de exclusão iônica (marca Biorad, modelo Aminex HPX-87H, Hercules, CA, USA) a $60{ }^{\circ} \mathrm{C}$, utilizando-se $\mathrm{H}_{2} \mathrm{SO}_{4} 8 \mathrm{mM}$ como fase móvel a uma vazão de 0,6

$\mathrm{mL} \cdot \mathrm{min}^{-1}$. Estes compostos foram detectados num refratômetro diferencial (marca Waters, 
modelo 2414, Milford, MA, USA). A amostragem para quantificação da concentração residual do substrato limitante no meio de cultura para cultivos em quimiostato foi realizada conforme metodologia descrita por Mashego et al. (2003). Para tal, amostras foram coletadas com seringa, contendo em seu interior esferas de aço inoxidável (62 g, $4 \mathrm{~mm}$ de diâmetro) previamente resfriadas a $-18{ }^{\circ} \mathrm{C}$. A amostra foi imediatamente filtrada por pressão positiva em filtros de porosidade 0,22 $\mu \mathrm{m}$. Esse método, conhecido como "Cold Steel Beads", permite que a temperatura final da amostra atinja o valor de $1{ }^{\circ} \mathrm{C}$ muito rapidamente. Com isso, evita-se que a pequena quantidade de substrato existente na amostra seja consumida pelo microrganismo, o que ocorre durante procedimentos usuais de amostragem. Os açúcares em amostras contendo sacarose, glicose e frutose, foram quantificados por kit enzimático, conforme orientações do fabricante (Boehringer Mannheim, Cat. Nr. 10716260 035) ou mediante cromatografia líquida de troca aniônica (marca Dionex, modelo DX-300, Sunnyvale, CA, USA), coluna Carbopak PA-1 e detector de amperometria de pulso, tendo $\mathrm{NaOH} 100 \mathrm{mM}$ como fase móvel a um fluxo de 0,9 mL. $\mathrm{min}^{-1}$. Esta última análise foi realizada no laboratório do Prof. Dr. Luiz Carlos Basso (ESALQ, USP).

A determinação de trealose e glicogênio nas células foi realizada segundo Hazelwood et al. (2009).

\subsection{Quantificação da concentração celular}

Nos cultivos em frasco agitado, a concentração celular foi determinada indiretamente pela medida da $\mathrm{Abs}_{600}$ em espectrofotômetro (marca Thermo Scientific, modelo Genesys 20, West Palm Beach, FL, USA). No caso das amostras dos quimiostatos, a concentração celular foi também determinada em termos de massa seca de células. Para tanto, parte da amostra foi filtrada a vácuo em membrana de porosidade 0,45 $\mu \mathrm{m}$ (Millipore). Antes de se interromper a filtração, o "pellet" celular foi lavado duas vezes com água destilada e então a amostra foi levada ao forno de microondas numa potência de 180 W por 15 min. A diferença entre a massa da membrana contendo o "pellet" seco de células e a massa da membrana seca, sem células, foi então dividida pelo volume de amostra utilizado na filtração. Determinações em duplicata variaram menos que $3 \%$. Para que esta determinação fosse precisa, utilizou-se um volume de amostra tal que a massa seca de células retidas na membrana estivesse entre 25 e 50 mg Olsson e Nielsen (1997). 


\subsection{Inspeção da pureza da cultura}

A partir de algumas amostras, foram preparadas lâminas a fresco para a inspeção da pureza dos cultivos por microscopia luminosa, com aumento de 400 vezes.

\subsection{Medida da capacidade fermentativa}

Para a avaliação da capacidade fermentativa das células, amostras do cultivo foram coletadas em tubos de $50 \mathrm{~mL}$, em quantidade suficiente para se obter $100 \mathrm{mg}$ (massa seca) de "pellet" após centrifugação ( $4 \min$ a $4000 \mathrm{~g}$ a $4^{\circ} \mathrm{C}$ ). $\mathrm{O}$ "pellet" de células foi ressuspenso em $10 \mathrm{~mL}$ de meio sintético definido $5 \mathrm{X}$ concentrado, e sem a fonte de carbono (Verduyn et al., 1992) e o conteúdo vertido em recipiente para avaliação da capacidade fermentativa. O tubo de $50 \mathrm{~mL}$ foi então lavado com $30 \mathrm{~mL}$ de água e o conteúdo da lavagem também adicionado ao recipiente. Em seguida, o "headspace" do recipiente foi saturado com gás $\mathrm{CO}_{2}$ $\left(30 \mathrm{~mL} \cdot \mathrm{min}^{-1}\right.$ ) para se obter ambiente de plena anaerobiose à temperatura de $30{ }^{\circ} \mathrm{C} . \mathrm{O}$ ensaio foi iniciado com a adição de $10 \mathrm{~mL}$ de solução de glicose ou sacarose $10 \%(\mathrm{p} / \mathrm{v})$ ao recipiente. Após isto, acompanhou-se (amostragens a cada 5 min num período de $30 \mathrm{~min}$ ) a formação de etanol, o qual é produzido pelas células em quantidade equimolar ao $\mathrm{CO}_{2}$ (assumindo-se metabolismo puramente fermentativo). A capacidade fermentativa é expressa em mmol ETH.(g DW.h $)^{-1}$.

\subsection{Determinação da atividade de invertase extracelulare total}

A atividade de invertase extracelular foi determinada conforme metodologia adaptada de Silveira et al. (1996). Para tanto, um volume de amostra do cultivo foi submetido a centrifugação e a massa de células obtida foi utilizada para preparar uma suspensão de células a $20 \mathrm{~g} . \mathrm{L}^{-1}$ em água destilada. Em seguida, as células íntegras foram tratadas com tampão Tris-succinato $\mathrm{pH} \mathrm{5,0} \mathrm{contendo} \mathrm{Fluoreto} \mathrm{de} \mathrm{Sódio,} \mathrm{que} \mathrm{atua} \mathrm{como}$ inibidor da enolase (uma das enzimas da via glicolítica). Uma solução de sacarose foi adicionada às células e a glicose formada por hidrólise do dissacarídeo, presente no 
sobrenadante, foi determinada com auxílio de kit enzimático, conforme orientações do fabricante (Boehringer Mannheim, Cat. Nr. 10716260 035, Ingelheim am Rhein, Germany).

Para a determinação da atividade da invertase total, utilizaram-se células permeabilizadas, conforme adaptado de Stambuk et al. (1999). Um volume de amostra do cultivo foi submetido à centrifugação, e a massa de células obtida foi utilizada para preparar uma suspensão de células a 20 g. L $^{-1}$ em água destilada. Em seguida, as células foram tratadas com tampão Tris-succinato pH 5,0 e com uma solução de permeabilização (Etanol:Triton X100:Tolueno, 1:4:1). Uma solução de sacarose foi adicionada às células e a glicose formada por hidrólise do dissacarídeo foi determinada com auxílio de kit enzimático, conforme orientações do fabricante (Boehringer Mannheim, Cat. Nr. 10716260 035).

\subsection{Determinação da atividade do transporte de sacarose}

A atividade do transporte de sacarose foi determinada por duas metodologias diferentes. Nos experimentos realizados na USP, mediu-se o transporte de $\left[\mathrm{U}-{ }^{14} \mathrm{C}\right]$ sacarose (Amersham Biosciences, Pittsburgh, PA, USA), utilizando-se células íntegras através da técnica adaptada de Stambuk et al. (1998). Para isto, $36 \mu \mathrm{L}$ de uma suspensão celular a 30 g. $\mathrm{L}^{-1}$ foram misturados a $36 \mu \mathrm{L}$ de Tampão $50 \mathrm{mM}$ Tris-succinato $\mathrm{pH}$ 5,0 e incubados em banho por $3 \mathrm{~min}$, a $30^{\circ} \mathrm{C}$. Após esse período, adicionou-se $18 \mu \mathrm{L}$ de uma solução $100 \mathrm{mM}$ de $\left[\mathrm{U}-{ }^{14} \mathrm{C}\right]$ sacarose (perfazendo uma concentração final de sacarose de $20 \mathrm{mM}$ ), $50 \mathrm{mM}$ de glicose e $50 \mathrm{mM}$ de frutose, mantendo-se as amostras incubadas em banho a $30^{\circ} \mathrm{C}$. A adição de glicose e frutose não marcadas é utilizada para diluir o efeito da possível assimilação de $\left[\mathrm{U}-{ }^{14} \mathrm{C}\right]$ glicose e $\left[\mathrm{U}-{ }^{14} \mathrm{C}\right]$ frutose, as quais podem ser oriundas da hidrólise extracelular da [U${ }^{14} \mathrm{C}$ ]sacarose (Santos et al., 1982). Após intervalos de tempo pré-estabelecidos, alíquotas foram coletadas e rapidamente filtradas em membranas com porosidade de 0,45 $\mu \mathrm{m}$ (Millipore). A seguir, as membranas foram lavadas com $5 \mathrm{~mL}$ de água deionizada gelada e colocadas em frascos contendo $10 \mathrm{~mL}$ de líquido de cintilação. A radioatividade foi medida após $10 \mathrm{~h}$ em temperatura ambiente. Tais medidas foram realizadas no laboratório do Dr. Pedro de Araújo, no IQ/USP, pelo doutorando Marcelo G. Dário.

Nos experimentos realizados no LMI/TU Delft, o transporte de sacarose foi estimado indiretamente pelo co-transporte de íons $\mathrm{H}^{+}$. Para isto, utilizou-se uma concentração de sacarose de $70 \mathrm{mM}$, com células coletadas durante o estado estacionário de quimiostatos 
em anaerobiose limitados por sacarose (Stambuk et al., 2000). A s células foram coletadas em gelo $\left(4^{\circ} \mathrm{C}\right)$, centrifugadas $\left(4000 \mathrm{~g}, 5 \mathrm{~min}, 4^{\circ} \mathrm{C}\right)$ e lavadas duas vezes com água destilada $\left(4{ }^{\circ} \mathrm{C}\right)$. O "pellet" (25 mg DW) foi ressuspenso em $3 \mathrm{~mL}$ de tampão ftalato de potássio $25 \mathrm{mM}$ e pH 5 e incubadas em recipiente apropriado, a $30{ }^{\circ} \mathrm{C}$, por 5 minutos. Após este período, adicionou-se uma solução de sacarose $1 \mathrm{M}$ (para resultar numa concentração final de 70 $\mathrm{mM}$ ) e a alcalinização inicial da suspensão celular foi acompanhada por cerca de 30-60 s com um $\mathrm{pH}$-metro de alta sensibilidade. Esta alcalinização reflete o transporte de $\mathrm{H}^{+}$que ocorre juntamente com o transporte da sacarose pelas células de levedura. Para calcular a velocidade de assimilação de $\mathrm{H}^{+}$, uma curva de calibração foi obtida pela adição de $100-500$ $\mathrm{nmol}$ de $\mathrm{NaOH}$ à suspensão celular. As velocidades iniciais de assimilação de $\mathrm{H}^{+}$foram calculadas a partir da inclinação dos primeiros 10-20 s da curva, registrados após a adição de sacarose, descontando-se a absorção basal de íons $\mathrm{H}^{+}$. Todas as determinações foram feitas ao menos em duplicata.

A determinação dos parâmetros cinéticos do transporte de sacarose ( $V_{\max }$ e $\left.K_{\mathrm{m}}\right)$ pelas linhagens iSUC2 e iSUC2 evoluída foram realizadas pelo doutorando Marcelo Goulart Dário, no Laboratório de Biologia Molecular e Biotecnologia de Leveduras da UFSC, coordenado pelo Prof. Dr. Boris U. Stambuk, de acordo com Stambuk et al. (2000). Para tanto, as celulas foram cultivadas em meio YP com sacarose a $2 \%(p / v)$, e coletadas durante a fase exponencial de crescimento. As células foram lavadas duas vezes com água destilada $\left(4^{\circ} \mathrm{C}\right)$ e resuspendidas em água destilada a $15 \mathrm{mg} \mathrm{DW} \cdot \mathrm{mL}^{-1}$. A suspensão celular foi incubada em recipiente apropriado termostatizado $\left(30^{\circ} \mathrm{C}\right)$ e $\mathrm{o} \mathrm{pH}$ da suspensão celular foi ajustado a 5 . Em seguida, pulsos de sacarose (1-150 mM) foram aplicados à suspensão celular, e a alcalinização inicial da mesma foi acompanhada por cerca de 30-60 s com um pH-metro de alta sensibilidade acoplado a um registrador gráfico TT1 Servograph (Radiometer, Copenhagen). Para calcular a velocidade de assimilação de $\mathrm{H}^{+}$, uma curva de calibração foi obtida pela adição de $10-200 \mathrm{nmol}$ de $\mathrm{HCl}$ à suspensão celular. As velocidades iniciais de assimilação de $\mathrm{H}^{+}$foram calculadas a partir da inclinação dos primeiros $10-20 \mathrm{~s}$ da curva, registrados após a adição de cada pulso de sacarose, descontando-se a absorção basal de íons $\mathrm{H}^{+}$.

Para o cálculo dos parâmetros cinéticos $\left(V_{\max }\right.$ e $\left.k_{m}\right)$ foi utilizado o método de Lineweaver e Burk (ou duplo-recíproco). 


\subsection{Manipulações genéticas}

\subsubsection{Eletroforese em gel de agarose}

$\mathrm{O}$ isolamento de fragmentos de DNA e a verificação dos produtos de PCR e dos produtos de digestão com enzimas de restrição foram realizados por meio da eletroforese do material genético em gel de agarose. Para isto, o gel de agarose (Sigma, St. Louis, USA) a $1 \%(p / v)$ foi preparado em tampão TAE (Tris-Acetato-EDTA) com corante SYBR ${ }^{\circledR}$ Safe Gel Stain (Invitrogen, Paisley, Scotland). As amostras de DNA foram adicionadas aos poços do gel juntamente com uma mistura contendo azul de bromo-fenol 0,25\% (p/v), xileno cianol $0,25 \%(\mathrm{p} / \mathrm{v})$ e glicerol $30 \%(\mathrm{p} / \mathrm{v})$ em água a $\mathrm{pH} 8,0-8,6$. A corrida eletroforética foi realizada em tampão TAE, a $90 \mathrm{~V}$, durante $40-60 \mathrm{~min}$.

\subsubsection{Reação em cadeia da polimerase (PCR)}

As amplificações foram realizadas utilizando-se um termociclador (marca Biômetra, modelo TGardient Thermocycler, Gottingen, Alemanha). Os reagentes utilizados foram provenientes de kits específicos. A quantidade empregada de primers, do DNA-molde (plasmidial ou genômico) e dos demais reagentes presentes na mistura reacional, foi de acordo com as instruções dos fabricantes (mencionados ao longo do texto). Similarmente, as condições para as reações de desnaturação, anelamento e extensão, em cada ciclo do PCR, foram estabelecidas de acordo com as instruções dos fabricantes dos kits.

\subsubsection{Transformação de leveduras pelo método do acetato de lítio}

As transformações genéticas descritas abaixo foram realizadas de acordo com Gietz e Schiestl (1995). O conteúdo de um tubo de cultura estoque da linhagem a ser manipulada geneticamente foi transferido para $20 \mathrm{~mL}$ de meio YPD líquido e incubado a $30{ }^{\circ} \mathrm{C} \mathrm{em}$ incubador rotativo por $12 \mathrm{~h}$. Após este período, uma alíquota foi transferida para $100 \mathrm{~mL}$ de meio YPD líquido, de modo que a $A_{b s} 600$ da cultura ficasse em torno de 0,3 . O frasco foi 
então incubado sob agitação a $30{ }^{\circ} \mathrm{C}$ por $4 \mathrm{~h}$. Em seguida, $50 \mathrm{~mL}$ da suspensão celular foram centrifugados a $4000 \mathrm{~g}$ por 5 minutos a $20^{\circ} \mathrm{C}$, as células foram ressuspensas em $25 \mathrm{~mL}$ de água destilada e centrifugadas novamente nas mesmas condições. As células foram ressuspensas em $1 \mathrm{~mL}$ de solução $100 \mathrm{mM}$ LiAc (acetato de lítio) e transferidas para um tubo eppendorf estéril. Esta suspensão foi centrifugada a $11600 \mathrm{~g}$ por 1 min à temperatura ambiente e as células ressuspensas em $400 \mu \mathrm{L}$ de solução 100 mM de LiAc.

Para cada reação de transformação, $50 \mu \mathrm{L}$ da suspensão celular foram transferidos para um novo tubo eppendorf e centrifugados por 1 min à temperatura ambiente para retirada do meio. Ao "pellet" celular foi adicionado, na seguinte ordem: $240 \mu \mathrm{L}$ de PEG $40 \%$ (p/v), $36 \mu \mathrm{L}$ de $1 \mathrm{M}$ LiAc, $25 \mu \mathrm{L}$ de suspensão de DNA de esperma de salmão desnaturado (2 $\left.\mathrm{mg} \cdot \mathrm{mL}^{-1}\right), 49 \mu \mathrm{L}$ de água destilada, e $1 \mu \mathrm{L}$ de suspensão do DNA transformante. A mistura foi então incubada por $30 \mathrm{~min}$ a $30^{\circ} \mathrm{C}$. Em seguida, novamente incubada por 30 min a $42{ }^{\circ} \mathrm{C}$. Terminada a incubação, a mistura foi centrifugada por $1 \mathrm{~min}$ a $11600 \mathrm{~g}$ a temperatura ambiente e as células ressuspensas em água destilada. Por fim, as células foram semeadas em placas com meio seletivo solidificado, conforme o tipo de marcador de seleção empregado.

\subsubsection{Reconstituição do gene URA3}

O gene URA3 foi inserido no genoma da linhagem BSY021-34B (iSUC2 ura-) por recombinação homóloga e metodologias baseadas em enzimas de restrição (Gietz e Schiestl, 1995). O plasmídeo pRS406 (Sikorski e Hieter, 1989) (Figura 4.2), extraído de uma cultura de

E. coli conforme orientações do fabricante (Gene Elute ${ }^{\mathrm{TM}}$ Plasmid Miniprep Kit, Sigma), foi clivado com as enzimas de restrição Ndel e Stul, e assim dois fragmentos foram obtidos (523 e $3861 \mathrm{pb}$ ). O fragmento menor, contendo regiões de homologia ao gene URA3, foi purificado seguindo orientações do fabricante (Zymoclean Gel DNA Recovery Kit, Zymo Research). Este cassete foi empregado para transformar a linhagem iSUC2 ura-(BSY021-34B) pela técnica de transformação de leveduras por acetato de lítio, substituindo-se, por recombinação homóloga, parte do alelo ura3-52 pelo novo cassete. Desta maneira, a reconstituição do gene URA3 nas células transformadas permitiu às mesmas crescerem em 
meio sintético definido sem uracila (ver item 4.2). Uma colônia foi resgatada e denominada IMI-056 (iSUC2).

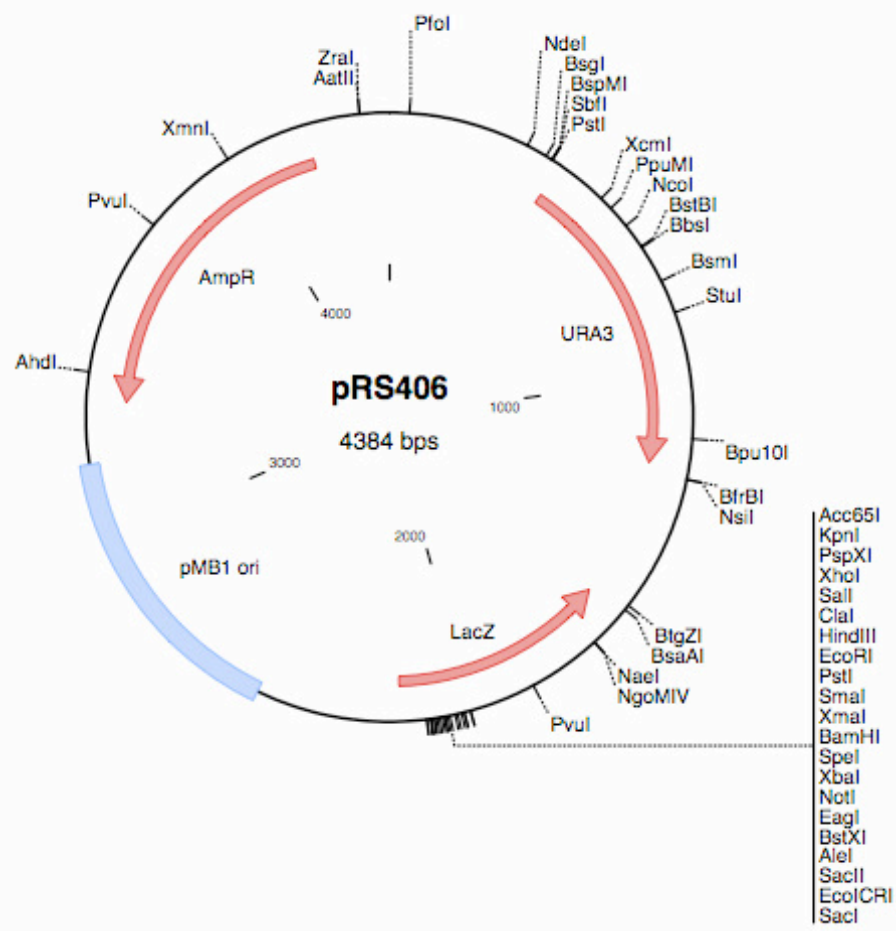

Figura 4.2 - Plasmídeo pRS406 utilizado para se obter o fragmento de 523 pb empregado para reconstrução do gene URA3 nas linhagens auxotróficas para a uracila.

\subsubsection{Deleção do gene AGT1}

O gene AGT1 foi deletado do genoma das linhagens CEN.PK113-7D (SUC2), IMI-056 (iSUC2) e IMM-007 (iSUC2 evoluída) por recombinação homóloga e metodologias baseadas em PCR (Gietz e Schiestl, 1995), gerando os transformantes IMK-308 (SUC2 Aagt1), IMK-305 (iSUC2 $\Delta a g t 1)$, e IMM-008 (iSUC2 evoluída $\Delta a g t 1)$, respectivamente. Através de PCR, os primers códigos 1470 e 1471 (Tabela 4.2) e o DNA genômico de uma linhagem $\Delta a g t 1$ derivada da linhagem S288C (BY4741), da coleção Saccharomyces Genome Deletion Project (YKO MATa Strain Collection-Glycerol Stocks, Open Biosystems, Thermo Scientific), extraído conforme orientações do fabricante (YeaStar Genomic DNA Kit, Zymo Research), produziram um fragmento linear de DNA com $\sim 2,7 \mathrm{~kb}$, portando em suas extremidades regiões homólogas às regiões imediatamente a montante (compreendendo $381 \mathrm{pb}$ ) e a jusante (compreendendo $644 \mathrm{pb}$ ) do gene $A G T 1$ e, entre essas extremidades, o cassete KanMX (uptag- $\mathrm{P}_{\text {TEF }}-k a n^{\mathrm{r}}{ }^{-} \mathrm{T}_{\text {TEF }}$ downtag, com $\sim 1,7 \mathrm{~kb}$ ), contendo o gene $k a n^{\mathrm{r}}$. Este novo cassete 
(AGT1-KO-KanMX) foi purificado (Genelute PCR Clean up Kit, Sigma), e em seguida empregado para transformar as linhagens pela técnica do acetato de lítio, substituindo-se, por recombinação homóloga, o gene AGT1 pelo cassete, o qual conferiu às células transformadas resistência à geneticina (G418) em meio YPD sólido com 200 mg. $\mathrm{L}^{-1}$ de G418.

Em seguida, os transformantes foram analisados por PCR diagnóstico através do isolamento do DNA genômico utilizando-se kit e seguindo as instruções do fabricante (YeaStar Genomic DNA Kit, Zymo Research) e empregando-se uma combinação de dois pares de primers (1472 e 9; 1473 e 10) (Tabela 2.2). A combinação de primers foi desenhada de maneira que um deles fosse anelado na região do cassete e a outra na região adjacente ao gene deletado. A inserção correta do cassete AGT1-KO-KanMX no genoma das leveduras permitiu uma amplificação de dois fragmentos (1010 e 1067 pb). Caso a inserção não tivesse ocorrido no sítio correto, não haveria produtos de amplificação com estes dois pares de primers.

Para verificar se o gene $A G T 1$ ainda estava presente nestes transformantes deletados no gene $A G T 1$, bem como para confirmar a presença do mesmo nas linhagens parentais, uma outra combinação de três pares de primers foi utilizada sobre o DNA genômico destas linhagens. A combinação dos primers 1563 e 1564 gerou um fragmento com 75 pb, que foi amplificado a partir de uma região interna ao gene AGT1. A combinação dos primers 1472 e 1564 gerou um fragmento com 1076 pb, que foi amplificado de uma região compreendida entre nucleotídeos a montante e nucleotídeos internos ao gene AGT1. Por fim, a combinação dos primers 1687 e 1688 gerou um fragmento com 1507 pb, novamente amplificado de outra região interna ao gene $A G T 1$.

Para a deleção do gene $A G T 1$ na linhagem IMM-008 (iSUC2 evoluída $\triangle a g t 1)$, que já continha em seu genoma o cassete AGT1-KO-KanMX, foi empregada outra estratégia de deleção. Através de PCR, os primers 1651 e 1652 (Tabela 2.2) e o plasmídeo pUG-hphN (Zelle et al., 2011) (Figura 4.3), extraído conforme orientações do fabricante (Qiagen midprep kit, Qiagen), produziram um fragmento linear de DNA com 1949 pb, portando em suas extremidades regiões homólogas às regiões a montante e a jusante do gene AGT1 e, entre essas extremidades, o gene $h p h N$. Este novo cassete (AGT1-KO-hphN) foi purificado (DNA Clean and Concentrator Kit, Zymo Research), e em seguida empregado para transformar a linhagem IMM-008 (iSUC2 evoluída $\Delta a g t 1$ ) pela técnica do acetato de lítio, substituindo-se, por recombinação homóloga, a outra cópia do gene AGT1 pelo cassete, o qual conferiu às 
células transformadas resistência à higromicina, permitindo o seu isolamento em meio YPD com 100 mg. L $^{-1}$ desta substância. A linhagem obtida, IMM-009 (iSUC2 evoluída $\Delta / \Delta$ agt1), foi analisada por PCR diagnóstico. Para verificar a inserção no local correto do cassete AGT1-KOhphN, foram empregados uma combinação de dois pares de primers (1007 e 1472; 1008 e 1473) (Tabela 2.2), os quais permitiram a amplificação de dois produtos (1405 e 1744 pb). Adicionalmente, utilizou-se uma outra combinação de dois pares de primers (1472 e 9; 1473 e 10) (Tabela 2.2), para verificar a presença do cassete AGT1-KO-KanMX, os quais permitiriam a amplificação de dois fragmentos (1010 e 1067 pb) caso as células tivessem em seu genoma a inserção do cassete. Por fim, empregou-se uma terceira combinação de primers (1687 e 1688; 1564 e 1472), que geraria os fragmentos de 1507 e 1226 pb, respectivamente, caso o transformante tivesse uma terceira cópia do gene AGT1. 
Tabela 4.2 - Primers utilizados.

\begin{tabular}{|c|c|c|}
\hline Primer & Código $^{(a)}$ & Seqüências $\left(5^{\prime} \rightarrow 3^{\prime}\right)$ \\
\hline Kan A & 9 & CGCACGTCAAGACTGTCAAG \\
\hline Kan B & 10 & TCGTATGTGAATGCTGGTCG \\
\hline MAL32 Probe RV & 942 & AGCAGCAAACAGCGTCTTGTC \\
\hline hphNT Ctrl Rv & 1007 & AGACGTCGCGGTGAGTTCAG \\
\hline hphNT Ctrl Fw & 1008 & ACGCGGATTTCGGCTCCAAC \\
\hline TPI1prom.CTRL-FW & 1067 & CTTTGGCTCGGCTGCTGTAAC \\
\hline MAL1 locus-CTRL-FW & 1084 & AGGCACAAGTACCAGGTGCTAAAG \\
\hline MAL11 Fw & 1145 & $\begin{array}{l}\text { CACCCATATGGTATAATATGAAAAATATCATTTCATTGGTAAGCAAGA } \\
\text { AG }\end{array}$ \\
\hline AGT1-KO upstream & 1470 & GCGAGTTGCAAGAATCTCTACG \\
\hline AGT1-KO downstream & 1471 & GATGACGACCACATGGGTTTG \\
\hline AGT1 Ctrl Fw & 1472 & GCCTCTTTCCACCACTTTG \\
\hline AGT1 Ctrl Rv & 1473 & ACGAGGACTGTCAGACCATTG \\
\hline Fw MAL11 qPCR & 1563 & CAGCCCTGTGGTCCATATTAGTG \\
\hline Rv MAL11 qPCR & 1564 & ACAGTGCGCTCAGTAGTGC \\
\hline AGT1 KO Fw B & 1651 & TCATTTCATTGGTAAGCAAGAAGAAGGCTGCCTCAAAAATGAGGATA \\
\hline & 1051 & AAAACATCAGCTGAAGCTTCGTACGC \\
\hline AGT1 KO Rv B & 1652 & $\frac{\text { CATTTATCAGCTGCATTIAATTCTCGCTGTTITATGCTTGAGGACTGACT }}{\text { GATACGCATAGGCCACTAGTGGATCTG }}$ \\
\hline MAL13 Prom Repl Fw & 1653 & $\frac{\text { AAGTAAATGAAAAGTAGAAAATTTAGCCAGAACTCTTITTTGCTTCGAG }}{\text { ICAGCTGAAGCTTCGTACGC }}$ \\
\hline MAL13 Prom Repl Rv & 1654 & $\frac{\text { CGACAGCAGTCGCATTGCCTGCTTGGCGCATGTTTGCTTAGTTAAAGTCA }}{\text { IGCGGAGTTTATGTATGTGTTTTTTG }}$ \\
\hline MAL13 Prom Repl Ctrl Fw & 1655 & TAAAGTCCGGGTGACCTGG \\
\hline MAL13 Prom Repl Ctrl Rv & 1656 & СССTCTGCACTTCTGCTATTC \\
\hline MAL13 KO Fw A & 1668 & $\frac{\text { CTCGATATATATTAAAGTAAATGAAAAGTAGAAAATTTAGCCAGAACTC }}{\text { ICAGCTGAAGCTTCGTACGC }}$ \\
\hline & & CACAGTTTCTACAATGGAAAGCTATCACTTACCAGGAAGTTGAGATGCA \\
\hline MAL13 KO Rv A & 1669 & CGCATAGGCCACTAGTGGATC \\
\hline & & TG \\
\hline MAL13 Ctrl Fw & 1672 & ATAAAGTCCGGGTGACCTGGG \\
\hline MAL13 Ctrl Rv & 1673 & CCAATCTGGCTCTTAGCACTC \\
\hline MAL13 inside Fw & 1674 & CGGTCCTAACACCATTGCAACTG \\
\hline MAL13 inside Rv & 1675 & CAAGTTGCGGTGGTGCTATTGTG \\
\hline AGT1 inside Fw & 1687 & CCACCAATTCAGCCCAGTTAG \\
\hline AGT1 inside Rv & 1688 & AAGGTTCTACCAGTTGTCTCAGGCAGATCG \\
\hline MAL11 Seq Fw 1 & sc & CAGCCCTGTGGTCCATATTAG \\
\hline MAL11 Seq Fw 2 & sc & TGGCCTGCTCCTTTAATGATCG \\
\hline MAL11 Seq Fw 3 & sc & CTGGTATCGGTGCAGTTG \\
\hline MAL11 Seq Rv 1 & sc & TGTCCCACAGCAATCATAGC \\
\hline MAL11 Seq Rv 2 & sc & GCAGCCTTCTTCTTGCTTACC \\
\hline \multicolumn{3}{|c|}{$\begin{array}{l}\text { (a) Código referente ao banco de dados do Laboratório de Microbiologia Industrial da Delft University of } \\
\text { Technology, Holanda. Os nucleotídeos em negrito e sublinhados nos primers de deleção referem-se às regiões } \\
\text { de homologia ao genoma de } S \text {. cerevisiae, obtidos da base de dados "Saccharomyces Genome Database" } \\
\text { (SGD). }\end{array}$} \\
\hline
\end{tabular}




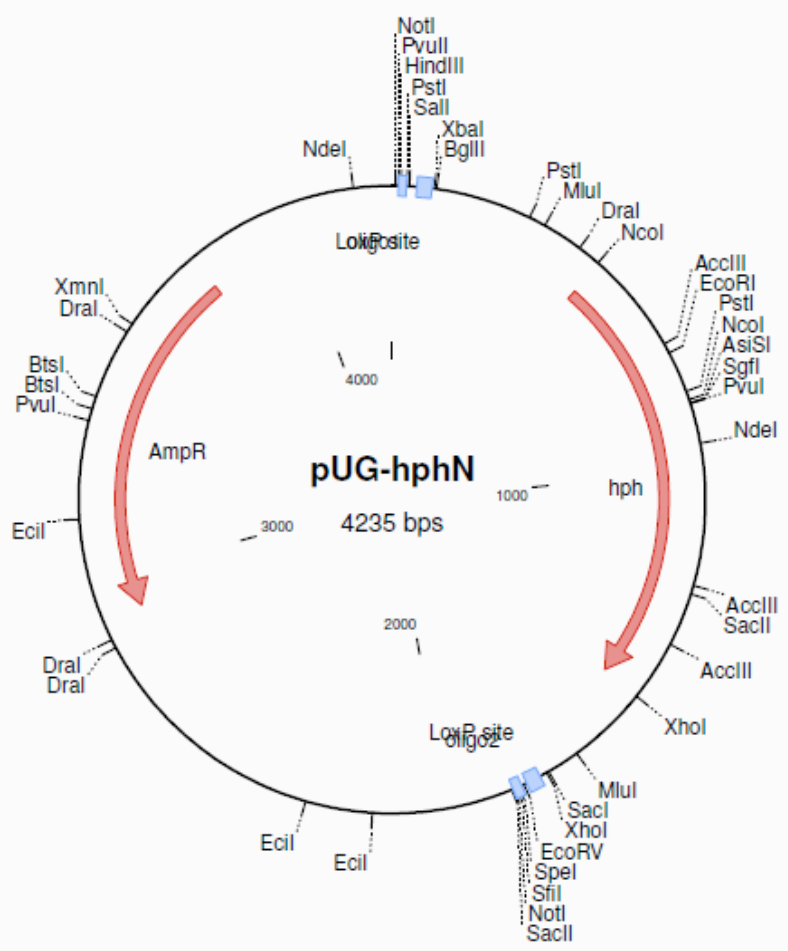

Figura 4.3 - Plasmídeo pUGhphN utilizado para se obter o cassete de transformação com 1949 pb para deleção da cópia extra do gene AGT1 na linhagem IMM-008 (iSUC2 evoluída $\Delta$ agt1).

\subsubsection{Deleção do gene MAL13}

Esta etapa do trabalho foi realizada pelo aluno de doutoramento, Stefan de Kok, do LMI/TU Delft, que é um colaborador deste trabalho.

O gene MAL13 foi deletado do genoma da linhagem IMM-007 (iSUC2 evoluída) por recombinação homóloga e metodologias baseadas em PCR (Gietz e Schiestl, 1995), gerando o transformante IMM-010 (iSUC2 evoluída $\Delta$ mal13). Através de PCR, os primers 1668 e 1669 (Tabela 4.2) e o plasmídeo pUG-hphN (Zelle et al., 2011) (Figura 4.3), extraído conforme orientações do fabricante (Qiagen midprep kit, Qiagen), produziram um fragmento linear de DNA com 1939 pb portando em suas extremidades regiões homólogas à região a montante e a jusante do gene MAL13 e, entre essas extremidades, o gene hphN. Este novo cassete (MAL13-KO-hphN) foi purificado (DNA Clean and Concentrator Kit, Zymo Research), e em seguida empregado para transformar as linhagem IMM-007 (iSUC2) pela técnica do acetato de lítio, substituindo-se, por recombinação homóloga, o gene MAL13 pelo cassete, o qual conferiu às células transformadas resistência à higromicina, permitindo o seu isolamento em 
meio YPD com 100 mg. L $^{-1}$ desta substância. A linhagem obtida, IMM-010 (iSUC2 evoluída $\Delta m a / 13)$, foi analisada por PCR diagnóstico, empregando-se uma combinação de dois pares de primers (1008 e 1672; 1007 e 1673) (Tabela 4.2), os quais permitiram a amplificação de dois fragmentos (695 e 1078 pb) caso as células tivessem em seu genoma a inserção correta do cassete MAL13-KO-hphN. Adicionalmente, empregou-se outra combinação de primers internos ao gene MAL13 (1674 e 1675), que geraria um fragmento de 587 pb, caso o transformante tivesse uma outra cópia do gene MAL13.

\subsubsection{Substituição do promotor do gene MAL13}

Para a substituição do promotor nativo do gene $M A L 13$, pelo promotor forte $\mathrm{P}_{T P \mid 1}$, foi utilizado outro cassete de DNA. Através de PCR (Expand High Fidelity PCR System, Roche), os

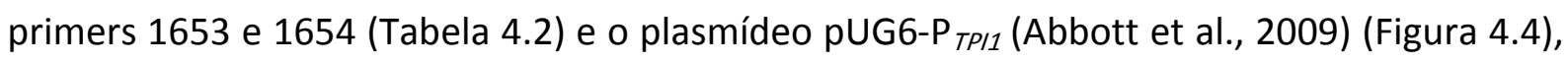
extraído conforme orientações do fabricante (Qiagen miniprep kit, Qiagen), produziram um fragmento linear de DNA com 2301 pb portando em suas extremidades regiões homólogas às regiões a montante e a jusante da região promotora do gene $M A L 13 \mathrm{e}$, entre essas extremidades, o cassete loxP-KanMX-loxP-P $\mathrm{P}_{T P I 1}$. Este novo cassete foi purificado (DNA Clean and Concentrator Kit, Zymo Research), e em seguida empregado para transformar a linhagem IMI-056 (iSUC2) pela técnica do acetato de lítio, substituindo-se, por recombinação homóloga, o promotor original pelo novo promotor $\left(\mathrm{P}_{T P / 1}\right)$ e gerando assim a linhagem IMI066 (iSUC2 $\mathrm{P}_{\mathrm{TPI} 1}-$ MAL13). Os transformantes foram selecionados em meio YPD contendo Geneticina. Por fim, os transformantes foram analisados por PCR (FastStart PCR Master, Roche) diagnóstico através de técnica conhecida como "colony $P C R$ ", empregando-se uma combinação de dois pares de primers (9 e 1655; 1067 e 1656) (Tabela 2.2), os quais permitiriam uma amplificação de dois fragmentos (375 e 396 pb) caso as células tivessem em seu genoma a inserção no sítio correto do cassete loxP-KanMX-loxP-P $\mathrm{P}_{T P I 1}$. 


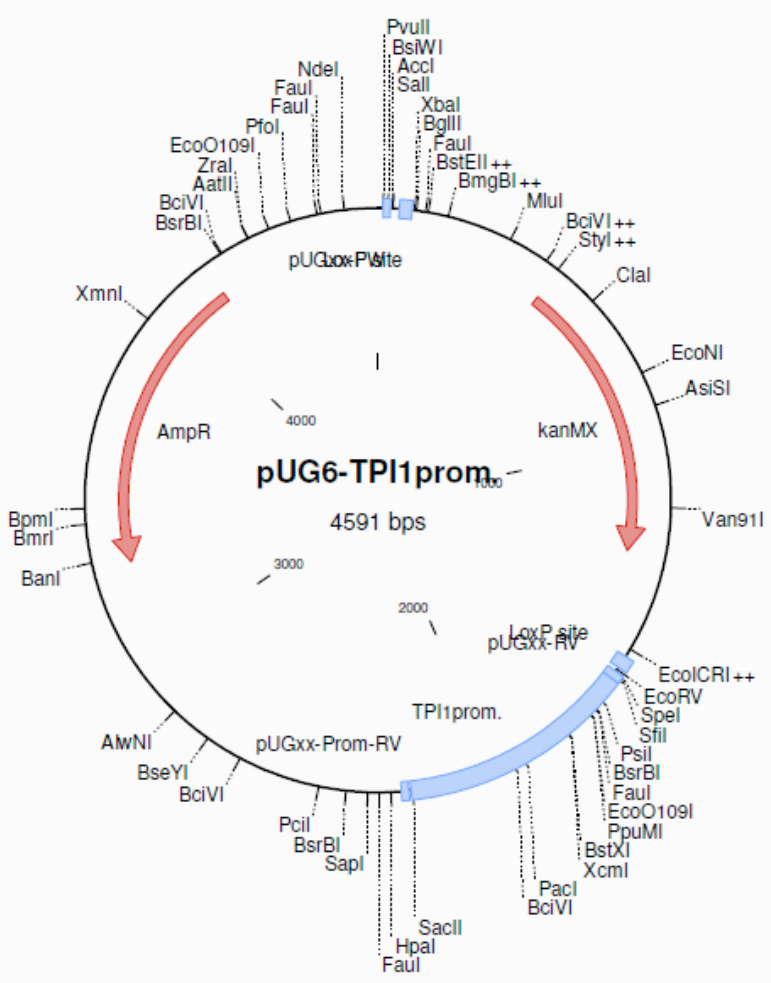

Figura 4.4 - Plasmídeo pUG6-TPI1prom utilizado para se obter o cassete de transformação com 2301 pb para obtenção da linhagem que superexpressa o gene MAL13 por ação do promotor forte $\mathrm{P}_{\text {TPI1 }}$ (IMI066; iSUC2 $\mathrm{P}_{\text {TPII }}$ MAL13).

\subsubsection{Super-expressão do gene AGT1}

Esta etapa do trabalho foi realizada pelo aluno de doutoramento, Stefan de Kok do LMI/TU Delft, que é um colaborador deste trabalho. O plasmídeo pAG306GPD-MAL11 (Figura 4.5), que contém o gene $A G T 1(M A L 11)$ amplificado do DNA genômico da linhagem CEN.PK113-7D, foi clivado com a enzima de restrição Stul e o cassete resultante foi integrado no lócus ura3-52 da linhagem BSY021-34B (iSUC2 ura-), gerando a linhagem IMI-067 (iSUC2 $\mathrm{P}_{\text {TDH3 }}$ AGT1). 


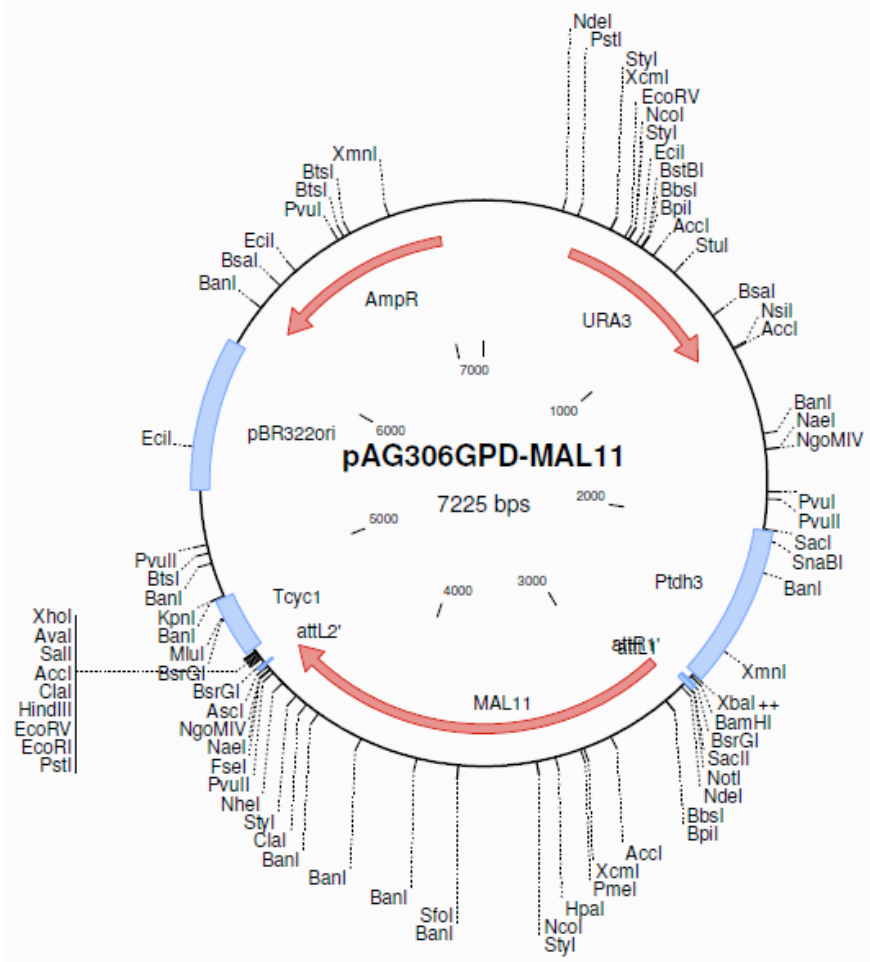

Figura 4.5 - Plasmídeo pAG306GPD-MAL11 utilizado para se obter o cassete de transformação com 7725 pb para obtenção da linhagem que superexpressa uma cópia extra do gene AGT1 por ação do promotor forte $\mathrm{P}_{T D H 3}$ (IMI-067; iSUC2 $\mathrm{P}_{T D H 3}$ AGT1).

\subsection{Análise da expressão gênica em escala genômica (transcriptoma)}

Esta etapa do trabalho foi realizada em parceria com o grupo coordenado pelo $\mathrm{Dr}$. Jack Pronk, colaborador deste projeto, nas dependências do LMI/TU Delft. A análise dos micro-arranjos de DNA foi conduzida com arranjos S98 Yeast GeneChip da Affymetrix (Santa Clara, CA) conforme descrito anteriormente (Piper et al., 2002) e coordenada pelo Dr. JeanMarc Daran. As células foram transferidas diretamente dos quimiostatos em anaerobiose para um frasco com nitrogênio líquido e processadas de acordo com as instruções do fabricante (Manual técnico da Affymetrix), com as seguintes modificações. A síntese de cDNA de fita-dupla foi conduzida empregando-se $15 \mu \mathrm{g}$ de RNA total e os componentes do "One Cycle cDNA Synthesis Kit" (Affymetrix). O cDNA de fita-dupla foi purificado (GeneChip Sample Cleanup Module, Qiagen) antes das etapas de transcrição in vitro e marcação (GeneChip IVT Labelling Kit, Affymetrix). Por fim, o cRNA marcado foi purificado (GeneChip Sample Cleanup Module) antes das etapas de fragmentação e hibridização empregando-se $15 \mu \mathrm{g}$ de cRNA-biotina. Os resultados de expressão gênica para cada linhagem foram obtidos a partir de 2 replicatas biológicas (dois cultivos independentes) (De Nicola et al., 2007). 
A aquisição e a quantificação das imagens dos arranjos, bem como a filtragem dos dados, foram conduzidas usando o programa de operação Affymetrix Genechip, versão 1.2.

O "add-in" "Significance Analysis of Microarrays" (SAM), versão 1.12 (Tusher et al., 2001) do Microsoft Excel foi utilizado para análise estatística dos resultados de expressão gênica obtidos para cada linhagem (iSUC2, iSUC2 evoluída e SUC2). As comparações realizadas ("pairwise comparison") foram: entre a linhagem iSUC2 e a linhagem iSUC2 evoluída, bem como entre a linhagem iSUC2 e a linhagem-referência $S U C 2$, todas elas cultivadas em condições idênticas (quimiostatos limitados por sacarose em anaerobiose).

Grupos de genes que respondem igualmente a uma dada condição experimental foram avaliados quanto a sua super-representação em categorias funcionais (MIPS e KEGG) usando testes hipergeométricos, conforme descrito por Knijnenburg et al. (2007) e Kresnowati et al. (2006).

\subsection{Sequenciamento do gene $A G T 1$}

Para o sequenciamento do gene $A G T 1$ presente nas linhagens iSUC2, iSUC2 evoluída e iSUC2 evoluída $\triangle a g t 1$, foi necessário, primeiramente, extrair o DNA genômico das mesmas segundo protocolo padrão (YeaStar Genomic DNA Kit, Zymo Research). Em seguida, o alelo presente em cada linhagem foi amplificado (Phusion Hot Start, High-Fidelity DNA polymerase, Finnzymes) com os primers 1084 e 942, gerando o produto com 4476 pb, no caso das duas primeiras linhagens, e com as combinações de primers 1084 e 1145, e 1472 e 1564, gerando os produtos com 2097 e 1226 pb, respectivamente, no caso da linhagem iSUC2 evoluída $\Delta a g t 1$ (Tabela 2.2). Tais produtos de PCR foram então purificados (DNA Clean and Concentrator Kit, Zymo Research) e encaminhados, juntamente como os primers MAL11 seq-Fw1, -Fw2, -Fw3, -Rv1 e -Rv2 (Tabela 2.2) à empresa Baseclear (Leiden, Holanda), para serem seqüenciados.

\subsection{Cálculo dos parâmetros fisiológicos}

Os parâmetros fisiológicos (fator de conversão de substrato a células, fator de conversão de substrato a etanol, velocidade específica de produção de produto e velocidade 
específica de consumo de substrato) dos cultivos realizados foram calculados segundo Schmidell et al., 2001. 


\section{RESULTADOS E DISCUSSÃO}

No Quadro 5.1 é apresentada uma visão geral de todos os experimentos realizados em biorreator ou em frasco agitado, durante este trabalho de tese de doutoramento. 
Quadro 5.1: Quadro-resumo dos experimentos realizados

\begin{tabular}{|c|c|c|c|c|c|c|}
\hline Linhagem $^{(\mathrm{a})}$ & Sigla (LMI/TU Delft) & Modo de cultivo & Fonte de Carbono & Limitação nutricional & Condição & Local \\
\hline SUC2 ura- & CEN.PK113-5D & Quimiostato & Sacarose & Sacarose & Aerobiose & LEB/USP \\
\hline SUC2 ura- & CEN.PK113-5D & Quimiostato & Sacarose & Sacarose & Anaerobiose & LEB/USP \\
\hline iSUC2 ura- & BSY021-34B & Quimiostato & Sacarose & Sacarose & Aerobiose & LEB/USP \\
\hline iSUC2 ura- & BSY021-34B & Quimiostato & Sacarose & Sacarose & Anaerobiose & LEB/USP \\
\hline SUC2 ura- & CEN.PK113-5D & Quimiostato* & Glicose & Glicose & Aerobiose & LEB/USP \\
\hline SUC2 ura- & CEN.PK113-5D & Quimiostato* & Glicose & Glicose & Anaerobiose & LEB/USP \\
\hline iSUC2 ura- & BSY021-34B & Quimiostato* & Glicose & Glicose & Aerobiose & LEB/USP \\
\hline iSUC2 ura- & BSY021-34B & Quimiostato* & Glicose & Glicose & Anaerobiose & LEB/USP \\
\hline SUC2 & CEN.PK113-7D & Quimiostato & Sacarose & Sacarose & Anaerobiose & LMI/TU Delft \\
\hline iSUC2 & IMI-056 & Quimiostato & Sacarose & Sacarose & Anaerobiose & LMI/TU Delft \\
\hline iSUC2 evoluída & IMM-007 & Quimiostato & Sacarose & Sacarose & Anaerobiose & LMI/TU Delft \\
\hline iSUC2 evoluída $\triangle a g t 1$ & IMM-008 & Quimiostato* & Sacarose & Sacarose & Anaerobiose & LMI/TU Delft \\
\hline iSUC2 evoluída $\Delta a g t 1 / \Delta a g t 1$ & IMM-009 & Quimiostato & Sacarose & Sacarose & Anaerobiose & LMI/TU Delft \\
\hline iSUC2 $\mathrm{P}_{T P I I}-\mathrm{MAL} 13$ & IMI-066 & Quimiostato & Sacarose & Sacarose & Anaerobiose & LMI/TU Delft \\
\hline 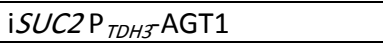 & IMI-067 & Quimiostato & Sacarose & Sacarose & Anaerobiose & LMI/TU Delft \\
\hline SUC2 & CEN.PK113-7D & Batelada repetida $(\mathrm{SBR})^{(\mathrm{b})}$ & Sacarose & & Anaerobiose & LMI/TU Delft \\
\hline iSUC2 & $\mathrm{IMI}-056$ & Batelada repetida (SBR) & Sacarose & & Anaerobiose & LMI/TU Delft \\
\hline iSUC2 evoluída & IMM-007 & Batelada repetida (SBR) & Sacarose & & Anaerobiose & LMI/TU Delft \\
\hline SUC2 Aagt1 & IMK-305 & Batelada repetida (SBR) & Sacarose & & Anaerobiose & LMI/TU Delft \\
\hline isUC2 $\triangle a g t 1$ & IMK-308 & Batelada repetida (SBR) & Sacarose & & Anaerobiose & LMI/TU Delft \\
\hline SUC2 ura- & CEN.PK113-5D & Shake-flask & Sacarose & & Aerobiose & LEB/USP \\
\hline SUC2 ura- & CEN.PK113-5D & Shake-flask & Glicose & & Aerobiose & LEB/USP \\
\hline iSUC2 ura- & BSY021-34B & Shake-flask & Sacarose & & Aerobiose & LEB/USP \\
\hline iSUC2 ura- & BSY021-34B & Shake-flask & Glicose & & Aerobiose & LEB/USP \\
\hline SUC2 ura- & CEN.PK113-5D & Quimiostato & Glicose & Uracila/Glicose & Aerobiose & LEB/USP \\
\hline SUC2 ura- & CEN.PK113-5D & Quimiostato & Sacarose & Uracila/Sacarose & Aerobiose & LEB/USP \\
\hline
\end{tabular}

(a) Todas as linhagens empregadas são da espécie Saccharomyces cerevisiae

(b) Nas bateladas repetidas (sequential batch reactors - SBR), o terceiro ciclo foi amostrado

NOTA: Todos os cultivos foram realizados em duplicata (exceto quando indicados, feitos em monoplicata*), a $30{ }^{\circ} \mathrm{C}$, $\mathrm{pH}$ controlado em 5,0 (no caso de cultivos em biorreator) e em meio de cultura definido (Verduyn et al., 1992). Todos os quimiostatos foram realizados a uma vazão específica de $0,10 \mathrm{~h}^{-1}$. Para mais detalhes experimentais, favor consultar a seção de Materiais e Métodos. 


\subsection{Efeitos da limitação por uracila em cultivos contínuos de $S$. cerevisiae}

Linhagens auxotróficas de leveduras constituem importantes plataformas utilizadas tanto para a pesquisa aplicada como para a pesquisa fundamental. $\mathrm{O}$ uso destas linhagens como estratégia para a detecção e a seleção de transformantes é uma ferramenta importante e eficaz no escopo da biologia molecular, principalmente quando o objetivo é utilizar a marcação auxotrófica para impedir a perda do(s) gene(s) introduzido(s) (Pronk, 2002). Um exemplo muito utilizado com linhagens de $S$. cerevisiae é a auxotrofia para a uracila. O gene URA3 codifica a enzima orotidina-5-fosfato descarboxilase (ODC), envolvida na síntese "de novo" de pirimidinas. Esta enzima cataliza a descarboxilação de orotidina-5fosfato (OMP) para uridina-5-fosfato (UMP), essencial na biossíntese de uracila na levedura S. cerevisiae. O alelo ura3-52 (ura-) é causado por uma inserção tipo Ty na região codificadora do gene funcional URA3, que por sua vez elimina a síntese da enzima ODC, deixando as células incapazes de sintetizar UMP pela via "de novo" (Rose e Winston, 1984).

Se não transformada com um alelo funcional do gene URA3, as células auxotróficas para a uracila só podem ser propagadas em meios que contenham esta substância em sua composição. Nesta situação, a uracila é captada pelas células por meio de um sistema de cotransporte com $\mathrm{H}^{+}$(Pantazopoulou e Diallinas, 2007), suprindo assim o requerimento de UMP pela via "salvage" de pirimidinas. A facilidade com que as linhagens auxotróficas e suas correspondentes complementadas podem ser manipuladas e os baixos custos dos reagentes envolvidos têm contribuído em muito para a construção de inúmeras linhagens laboratoriais com várias combinações de auxotrofia.

Como algumas linhagens (SUC2 ura- e iSUC2 ura-) utilizadas neste projeto são auxotróficas para a uracila, foi necessário definir uma concentração adequada desta substância no meio de cultivo. Existem divergências entre os trabalhos publicados na literatura, sobre os requerimentos nutricionais para linhagens auxotróficas, e, em especial, para a uracila. Numa referência importante sobre o tema (Sherman, 1991), sugere-se uma suplementação de uracila de $20 \mathrm{mg} \cdot \mathrm{L}^{-1}$ para meios sintéticos. Por outro lado, Pronk (2002) sugere uma suplementação de acordo com a concentração celular esperada, considerandose um teor de uracila na massa seca celular de 0,011 g.g DW-1 (Oura, 1972 apud Pronk,

\footnotetext{
${ }^{1}$ Oura E. The effect of aeration on the growth energetics and biochemical composition of baker's yeast [PhD Thesis]. Helsinki: University of Helsinki, 1972.
} 
2002) e um fator de acréscimo/segurança de 1,25. Por exemplo, num quimiostato em aerobiose com $S$. cerevisiae, com uma concentração de glicose de 10 g. $\mathrm{L}^{-1}$ no meio de alimentação, espera-se uma concentração de biomassa seca de cerca de $5 \mathrm{~g}$ DW. L $^{-1}$ (assumindo-se um $\mathrm{Y}_{\mathrm{x} / \mathrm{s}}$ de 0,5 g DW. $\mathrm{g}^{-1}$ ). Logo, é possível calcular uma suplementação de uracila ao redor de $70 \mathrm{mg} \cdot \mathrm{L}^{-1}(0,011 \times 10 \times 0,5 \times 1,25)$. Como pode ser observado, existe uma grande variação entre o valor sugerido por Sherman (1991) e o sugerido por Pronk (2002). Assim, decidiu-se avaliar os efeitos das duas concentrações de uracila sobre a fisiologia da linhagem auxotrófica para este nutriente.

Durante o estado-estacionário de quimiostatos aeróbios limitados por glicose (e suplementados com $75 \mathrm{mg}$ de uracila. $\mathrm{L}^{-1}$ ) conduzidos com a linhagem auxotrófica para a uracila (SUC2 ura-), os principais parâmetros fisiológicos foram essencialmente iguais àqueles apresentados pela linhagem isogênica prototrófica (SUC2, CEN.PK113-7D) (Tabela 5.1). Assim, a uma $D$ de $0,10 \mathrm{~h}^{-1}$, o crescimento foi completamente respiratório, e nenhum metabólito foi detectado no meio de crescimento. Apesar desta observação parecer óbvia, foi decidido conduzir tal experimento, uma vez que a $\mu_{\max }$ é afetada pela suplementação nutricional. Ao crescerem, as células precisam transportar ativamente os nutrientes auxotróficos, e no caso da uracila, a ativação da via de utilização de pirimidina também é requerida (Pronk, 2002), o que implica em gasto adicional de energia.

No caso dos cultivos limitados por sacarose, como era esperado, o crescimento foi puramente respiratório. No entanto, o rendimento em biomassa foi $8 \%$ maior e a concentração de açúcares residuais 3 vezes maior, quando comparados aos mesmos parâmetros obtidos nos quimiostatos limitados por glicose. Vale destacar que dados obtidos durante quimiostatos limitados por sacarose são extremamente raros na literatura. Similarmente aos dados obtidos neste estudo, num dos raros trabalhos que relatam resultados nestas condições experimentais, reporta-se um rendimento em biomassa maior em sacarose do que em glicose (Barford et al.,1995).

Para o estudo da limitação por uracila, foi utilizada uma concentração de uracila de $20 \mathrm{mg} \cdot \mathrm{L}^{-1}$ no meio de alimentação. Esta concentração é a sugerida por um dos principais manuais sobre o cultivo de linhagens auxotróficas (Sherman, 1991). Considerando-se um conteúdo de uracila na biomassa de $0,011 \mathrm{~g}$ uracila.g DW-1 (Pronk, 2002), é possível calcular que a concentração celular máxima esperada para estes cultivos seria em torno de 1,8 g DW. $L^{-1}$, o que indicaria que em tais condições a uracila e não a glicose ou a sacarose seriam o 
nutriente limitante. Como observado na Tabela 5.1, as concentrações de biomassa alcançadas em cultivos com limitação de uracila foram próximas deste valor (considerandose uma concentração de açúcar de 10 g. $\mathrm{L}^{-1}$ no meio de alimentação, um rendimento em biomassa de 0,22 g DW. $\mathrm{g}^{-1}$, e uma concentração de açúcares residuais menores do que 0,6 $\mathrm{mM}$, é possível calcular uma concentração de biomassa de 2,1 g DW. $\mathrm{L}^{-1}$ ). Assim, nas condições de limitação de uracila, era esperado que as células não fossem consumir uma parte considerável do açúcar proveniente do meio de alimentação (uma vez que a $D$ de 0,10 $\mathrm{h}^{-1}$ sob regime de aerobiose, o rendimento em biomassa gira normalmente em torno de 0,5 g DW. $\left.g^{-1}\right)$. No entanto, isto não foi o observado, uma vez que $99 \%$ e $94 \%$ da fonte de carbono foi consumida nos quimiostatos conduzidos com glicose e com sacarose, respectivamente.

Tabela 5.1 - Parâmetros fisiológicos da linhagem SUC2 ura- (CEN.PK113-5D) durante o estado estacionário em quimiostatos aeróbios limitados por diferentes nutrientes. Os dados estão apresentados como a média e o desvio da média de dois experimentos independentes.

\begin{tabular}{|c|c|c|c|c|c|}
\hline \multirow{3}{*}{ Parâmetros fisiológicos ${ }^{(a)}$} & \multicolumn{3}{|c|}{ Sem limitação de uracila } & \multicolumn{2}{|c|}{ Com limitação de uracila } \\
\hline & \multicolumn{5}{|c|}{ Fonte de carbono } \\
\hline & Glicose $^{(a)}$ & Glicose $^{(\mathrm{b})}$ & Sacarose & Glicose & Sacarose \\
\hline$Y_{X / S}$ [g DW.(g GLC eq) $\left.^{-1}\right]$ & $0,50 \pm 0,01$ & 0,50 & $0,54 \pm 0$ & $0,22 \pm 0,00$ & $0,23 \pm 0,02$ \\
\hline$Y_{\mathrm{ETH} / \mathrm{s}}\left[\mathrm{g} \cdot(\mathrm{g} \text { GLC eq) })^{-1}\right]$ & 0 & 0 & 0 & $0,19 \pm 0,00$ & $0,13 \pm 0,01$ \\
\hline$q_{\mathrm{ETH}}\left[\mathrm{mmol} .(\mathrm{g} \mathrm{DW} . \mathrm{h})^{-1}\right]$ & 0 & 0 & 0 & $1,96 \pm 0,17$ & $1,2 \pm 0,09$ \\
\hline$q_{\mathrm{GLYc}}\left[\mathrm{mmol} .(\mathrm{g} \text { DW.h. })^{-1}\right]$ & 0 & 0 & 0 & $0,04 \pm 0,01$ & $0,02 \pm 0,00$ \\
\hline$q_{\mathrm{ACE}}\left[\mathrm{mmol} .(\mathrm{g} \mathrm{DW} . \mathrm{h})^{-1}\right]$ & 0 & 0 & 0 & $0,49 \pm 0,09$ & $0,29 \pm 0,08$ \\
\hline$\left.q_{\mathrm{s}}[\mathrm{mmol} \text { GLC eq. (g DW.h })^{-1}\right]$ & $1,1 \pm 0,1$ & 1,1 & $1,2 \pm 0,03$ & $2,67 \pm 0,26$ & $2,4 \pm 0,03$ \\
\hline $\mathrm{S}_{\text {RESIDUAL }}(\mathrm{mM})^{(\mathrm{d})}$ & $0,17 \pm 0,01$ & 0,17 & $0,54 \pm 0,11$ & $0,63 \pm 0,03$ & $1,75 \pm 0,39$ \\
\hline$q_{\mathrm{O} 2}\left[\mathrm{mmol} .(\mathrm{g} \mathrm{DW} . \mathrm{h})^{-1}\right]$ & $2,6 \pm 0,1$ & 2,2 & $2,2 \pm 0,2$ & $4,1 \pm 0,4$ & $4,1 \pm 0,6$ \\
\hline$q_{\mathrm{CO} 2}\left[\mathrm{mmol} .(\mathrm{g} \mathrm{DW} . \mathrm{h})^{-1}\right]$ & $2,8 \pm 0,0$ & 2,6 & $2,5 \pm 0,5$ & $6,1 \pm 0,2$ & $5,6 \pm 0,1$ \\
\hline $\mathrm{RQ}\left(\mathrm{q}_{\mathrm{CO} 2} / \mathrm{q}_{\mathrm{O} 2}\right)$ & $1,1 \pm 0,1$ & 1,2 & $1,1 \pm 0,1$ & $1,5 \pm 0,1$ & $1,4 \pm 0,2$ \\
\hline Balanço de C (\%) ${ }^{(d)}$ & & 95,5 & $95,0 \pm 5,1$ & $93,5 \pm 1,9$ & $89,5 \pm 3,2$ \\
\hline \multicolumn{6}{|c|}{ 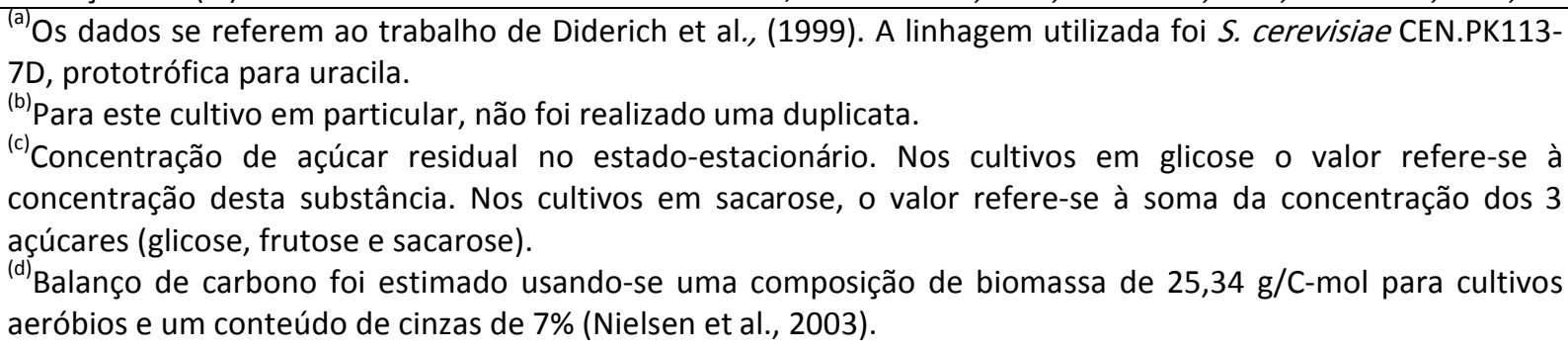 } \\
\hline
\end{tabular}

Observa-se ainda, pelos dados apresentados na Tabela 5.1, que a limitação por uracila resulta num metabolismo respiro-fermentativo, mesmo em condições nas quais as células, quando limitadas pela fonte de carbono, normalmente apresentariam um metabolismo puramente respiratório. Este comportamento é, em parte, semelhante aos 
cultivos limitados por outros nutrientes, tais como nitrogênio $(N)$, fósforo $(P)$, e enxofre $(S)$ (Diderich et al., 1999; Bôer et al., 2003). O aumento nas $q_{\mathrm{GLC}}$ e $q_{\mathrm{sUC}}$, o qual é resultado da menor eficiência energética da fermentação alcoólica (quando comparada ao metabolismo respiratório), foi acompanhado de um menor $Y_{x / s}$ (Tabela 5.1). Adicionalmente, não apenas a $q_{\mathrm{cO} 2}$, mas também a $q_{02}$ aumentaram mais de 2 vezes no cultivos limitados pela uracila, em relação aos cultivos com excesso deste nutriente.

As semelhanças entre os cultivos limitados por uracila e os cultivos limitados por N, P, e S são restritas às observações descritas acima. No primeiro caso, a concentração residual de glicose foi muito menor (na faixa de 1-2 mM) do que no segundo caso, onde uma concentração 10 vezes maior foi observada (Diderich et al., 1999; Bôer et al., 2003). Com isto, foi concluído que existe uma dupla limitação nutricional nos experimentos realizados com limitação de uracila: por carbono (glicose ou sacarose) e pela própria uracila, o que caracteriza uma situação fisiológica diferente da limitação nutricional por N, P ou S. Este fato foi também reportado por outros autores (Brauer et al., 2008; Boer et al., 2008).

Em alguns casos, a restauração da prototrofia em células auxotróficas, através da complementação com plasmídeos contendo os genes em questão, também resultaram em alterações na fisiologia destas células. Foi reportado que, no caso da auxotrofia pela leucina, as concentrações celulares na fase estacionária de cultivos descontínuos foram diferentes entre leveduras prototróficas e suas correspondentes auxotróficas nas quais os requerimentos nutricionais foram atendidos pela complementação genética (inserção de plasmídeo) ou pela suplementação do meio com o nutriente auxotrófico (Çakar et al., 1999).

Um fato curioso observado nos experimentos limitados por uracila foi que houve um aumento significativo na formação de acetato nos cultivos aeróbicos, tanto quando a fonte de carbono empregada foi glicose como sacarose (Tabela 5.1). As $q_{\text {ACE }}$ foram maiores do que as comumente observadas em quimiostatos anaeróbios com $S$. cerevisiae $[0,02 \mathrm{mmol}$.(g DW.h) $)^{-1}$, conforme reportado por Abbott et al., 2007] e semelhantes aos valores encontrados em quimiostatos aeróbios conduzidos acima da vazão específica crítica de alimentação $\left(D_{\text {crit }}\right)$. Segundo Postma et al. (1989), a $q_{\text {ACE }}$ foi igual a 0,6 mmol.(g DW.h $)^{-1}$, a uma $D$ de $0,35 \mathrm{~h}^{-1}$, em cultivos com a linhagem $S$. cerevisiae CBS 8066. Similarmente, em quimiostatos aeróbios limitados por glicose, conduzidos com uma linhagem de Bacillus subtilis auxotrófica para a metionina, níveis elevados de formação de acetato foram encontrados, quando a suplementação de metionina foi insuficiente (Çakar et al., 1999). 
É provável que este aumento na $q_{\mathrm{ACE}}$ em condições aeróbias pode ter sido resultado da atividade de uma rota metabólica conhecida como "desvio da piruvato desidrogenase", que normalmente opera sob condições respiro-fermentativas (Frick e Wittmann, 2005). Nesta via, que é uma alternativa à reação catalizada pela enzima piruvato desidrogenase, o piruvato é convertido a acetil-CoA pela ação seqüencial das enzimas piruvato descarboxilase, acetaldeído desidrogenase, e acetil-CoA sintetase. Isto, combinado a uma menor demanda biossintética por acetil-CoA (menor biomassa celular), sob condições de limitação de uracila, poderia levar ao acúmulo e subseqüente excreção de acetato ao meio de cultivo. Adicionalmente, como o acúmulo de acetato (um ácido orgânico fraco) no meio causa um efeito desacoplador na membrana celular (Verduyn et al., 1992), levando ao gasto de ATP (devido ao influxo de prótons) para a manutenção do $\mathrm{pH}$ intracelular, isto poderia explicar o aumento da $q_{02}$ sob limitação de uracila (Tabela 5.1). Nesta situação, as células iriam consumir oxigênio na cadeia transportadora de elétrons como forma de gerar ATP para propiciar a retirada de prótons, em vez de ser utilizado na síntese de biomassa.

Em resumo, a limitação por uracila, em quimiostato conduzido em aerobiose plena, resultou em metabolismo respiro-fermentativo e açúcar residual abaixo de $2 \mathrm{mM}$, indicando uma situação de dupla limitação nutricional (pela fonte de carbono e pela uracila, simultaneamente). Com isto, ocorre diminuição no $Y_{\mathrm{X} / \mathrm{S}}$ e aumento nas $q_{\mathrm{O} 2}$, $q_{\mathrm{CO} 2}$ e $q_{\mathrm{ACE}}$, em comparação a uma situação de excesso deste nutriente auxotrófico. Desta maneira, é possível afirmar que a suplementação insuficiente de uracila (seguindo indicações de alguns manuais para o cultivo de leveduras) resulta numa situação fisiológica claramente distinta de um quimiostato "clássico", limitado pela fonte de carbono, podendo levar a interpretações equivocadas em estudos quantitativos. 


\subsection{Estudo da relocalização do metabolismo da sacarose em cultivos contínuos}

Como apresentado na introdução desta tese (ver item 1), é de se esperar que uma levedura expressando apenas a forma intracelular da enzima invertase, quando cultivada em sacarose, seja obrigada a transportar este açúcar para o ambiente intracelular. Ao transportar uma molécula de sacarose para o ambiente intracelular, ocorre o co-transporte de $u m \mathrm{H}^{+}$, o que faz com que as células, para manterem o $\mathrm{pH}$ intracelular constante, tenham que bombear este próton para o ambiente extracelular. Isto ocorre via $\mathrm{H}^{+}$-ATPases de membrana, que gastam uma molécula de ATP por $\mathrm{H}^{+}$extrudado (Figura 1.1). Como balanço final, para cada mol de sacarose consumido pelas células em anaerobiose, em vez de serem gerados 4 moles de ATP via fermentação, são gerados apenas 3 moles de ATP (já que um mol é gasto para extrudar o $\mathrm{H}^{+}$co-transportado). Nesta situação, o que se espera é que as células, quando em anaerobiose, procurem repor estes $25 \%$ de ATP que deixam de ser gerados (ou ao menos parte disto) através de um incremento do fluxo de carbono para as vias fermentativas, ou seja, para a formação de etanol. Portanto, o que se imagina é que este cenário leve à formação de mais etanol por mol de sacarose consumido em anaerobiose do que numa situação de hidrólise extracelular da sacarose. Para verificar esta hipótese, o gene SUC2 de uma levedura da espécie $S$. cerevisiae foi alterado, de forma que a linhagem resultante superexpressasse, por ação do promotor forte $\mathrm{P}_{A D H 1}$, apenas a forma intracelular da enzima invertase (Stambuk et al., 2009).

\subsubsection{Modelo teórico do metabolismo de sacarose em anaerobiose}

A única diferença, em termos energéticos, entre células de $S$. cerevisiae que transportam sacarose ativamente e células que hidrolisam este dissacarídeo extracelularmente reside na etapa do transporte deste dissacarídeo. Normalmente, em S. cerevisiae, após a hidrólise extracelular da sacarose, a glicose e a frutose liberadas são transportadas através da membrana plasmática da levedura $S$. cerevisiae por difusão facilitada (transporte passivo), sem gasto de ATP (Heredia et al., $1968^{2}$ apud Serrano, 1977;

\footnotetext{
${ }^{2}$ Heredia CF, Sols A, DelaFuente G. Specificity of the constitutive hexose transport in yeast. Eur J Biochem. 1968;5:321-9.
} 
Lagunas, 1993). Por outro lado, o transporte de sacarose é ativo (Santos et al., 1982; Stambuk et al., 2000), e portanto implica no gasto de ATP durante a remoção dos $\mathrm{H}^{+}$cotransportados com a sacarose, pela $\mathrm{H}^{+}$-ATPase de membrana (Serrano, 1977; Lagunas, 1993).

No caso das células que hidrolisam a sacarose no ambiente extracelular, os parâmetros fisiológicos teóricos, em cultivos contínuos limitados por sacarose, podem ser obtidos a partir de modelos energéticos estabelecidos para cultivos contínuos limitados por glicose (Verduyn et al., 1990). De forma análoga, para células que hidrolisam sacarose no ambiente intracelular, modelos estabelecidos para cultivos contínuos limitados por maltose (Weusthuis et al., 1993) podem ser utilizados como referência.

A equação (1) apresenta a estequiometria para a formação de $100 \mathrm{~g}$ de biomassa celular (massa seca, DW) da levedura S. cerevisiae, em plena anaerobiose, a partir de glicose (Verduyn et al., 1990).

$5394 \mathrm{mmol}$ glicose -> $100 \mathrm{~g}$ de biomassa $+1102 \mathrm{mmol}$ de glicerol $+8240 \mathrm{mmol}$ de etanol $+8825 \mathrm{mmol}$ de $\mathrm{CO}_{2}$

A partir da equação (1), é possível calcular os valores para a formação da mesma quantidade de biomassa (100 g DW) durante o crescimento em sacarose, quando a hidrólise ocorre exclusivamente pela via extracelular.

$2697 \mathrm{mmol}$ de sacarose $=5394 \mathrm{mmol}$ de glicose e frutose $(1: 1)->100 \mathrm{~g}$ de biomassa +1102 $\mathrm{mmol}$ de glicerol $+8240 \mathrm{mmol}$ de etanol $+8825 \mathrm{mmol}$ de $\mathrm{CO}_{2}$

Para calcular os parâmetros fisiológicos teóricos em cultivos limitados por sacarose com células que transportam este dissacarídeo, primeiramente deve-se fazer algumas considerações, de forma análoga ao que já foi realizado em cultivos com maltose (Weusthuis et al., 1993). Como a estequiometria no co-transporte de sacarose- $\mathrm{H}^{+}$é de 1:1 (Serrano, 1977), e as $\mathrm{H}^{+}$-ATPases de membrana consomem $1 \mathrm{~mol}$ de ATP para remover $1 \mathrm{~mol}$ de $\mathrm{H}^{+}$ (Serrano et al., 1986), o requerimento em ATP para o transporte de sacarose é de 1 mol de 
ATP para cada $1 \mathrm{~mol}$ de dissacarídeo co-transportado. Assim, a produção líquida nesta situação é de $3 \mathrm{~mol}$ de ATP para cada $1 \mathrm{~mol}$ de sacarose metabolizado a etanol e $\mathrm{CO}_{2}$ (via fermentativa). Portanto, existe um déficit de $2697 \mathrm{mmol}$ de ATP para a formação de $100 \mathrm{~g}$ de biomassa (devido ao co-transporte de $2697 \mathrm{mmol}$ de sacarose) em relação ao crescimento em sacarose pela via extracelular. Tal déficit pode ser reposto pelo consumo adicional de $899(2697 / 3) \mathrm{mmol}$ de sacarose, os quais geram exatamente $2697 \mathrm{mmol}$ de ATP, segundo a equação (3):

$899 \mathrm{mmol}$ sacarose -> $3596 \mathrm{mmol}$ de etanol $+3596 \mathrm{mmol}$ de $\mathrm{CO}_{2}+2697 \mathrm{mmol}$ de ATP

Por meio das equações (2) e (3), é possível elaborar a equação para a formação de $100 \mathrm{~g}$ de biomassa através do metabolismo da sacarose exclusivamente pela via intracelular, ou seja, precedido pelo co-transporte com íons $\mathrm{H}^{+}$:

$3596 \mathrm{mmol}$ de sacarose $=7192 \mathrm{mmol}$ de glicose + frutose $\rightarrow 100 \mathrm{~g}$ de biomassa $+1102 \mathrm{mmol}$ de glicerol + $11836 \mathrm{mmol}$ de etanol $+12421 \mathrm{mmol}$ de CO2

Finalmente, através das equações (2) e (4), torna-se viável estimar os parâmetros fisiológicos teóricos durante cultivos em quimiostato a $D=0,10 \mathrm{~h}^{-1}$ em plena anaerobiose com sacarose como única fonte de carbono e energia, tanto para células que hidrolisam a sacarose extracelularmente, como para aquelas que a hidrolisam no ambiente intracelular (Tabela 5.2). Como se nota pelos dados apresentados na Tabela 5.2, devido à energética do transporte ativo de dissacarídeos (Weusthuis et al., 1993; Stambuk et al., 2000), é esperado que as células que transportam a sacarose (linhagem iSUC2) apresentem um maior fator de conversão de sacarose a etanol $\left(Y_{x / S}\right)$, em relação às células que a hidrolizam o dissacarídeo no ambiente extracelular (SUC2). 
Tabela 5.2 - Parâmetros fisiológicos teóricos, para o crescimento de $S$. cerevisiae em quimiostatos limitados por sacarose em plena anaerobiose $\left(D=0,10 \mathrm{~h}^{-1}\right)$. Os cálculos foram realizados tanto para uma situação de consumo de sacarose exclusivamente pela hidrólise extracelular, como para seu consumo exclusivamente pela hidrólise intracelular, precedida pelo co-transporte da sacarose com $\mathrm{H}^{+}$. Os cálculos foram baseados no modelo metabólico proposto por Verduyn et al., (1990) para, a linhagem $S$. cerevisiae CBS 8066.,

\begin{tabular}{|c|c|c|c|}
\hline \multirow[t]{2}{*}{ Parâmetro fisiológico } & \multicolumn{2}{|c|}{ Modo de consumo da sacarose } & \multirow[t]{2}{*}{ Relação INTRA/EXTRA (\%) } \\
\hline & $\begin{array}{l}\text { Invertase } \\
\text { extracelular }\end{array}$ & $\begin{array}{l}\text { Invertase } \\
\text { intracelular }\end{array}$ & \\
\hline$Y_{x / S}\left[g\right.$ DW. $\left.(g \text { GLC eq) })^{-1}\right]$ & 0,103 & 0,077 & -25 \\
\hline$Y_{\mathrm{ETH} / \mathrm{s}}\left[\mathrm{g}\right.$ ETH. $\left.(\mathrm{g} \text { GLC eq) })^{-1}\right]$ & 0,39 & 0,42 & 8 \\
\hline$q_{\text {ЕтH }}\left[\mathrm{mmol}(\mathrm{g} \text { DW.h })^{-1}\right]$ & 8,24 & 11,8 & 43 \\
\hline$q_{\mathrm{CO} 2}\left[\mathrm{mmol} .(\mathrm{g} \mathrm{DW} . \mathrm{h})^{-1}\right]$ & 8,83 & 12,4 & 40 \\
\hline$q_{\mathrm{GLYC}}\left[\mathrm{mmol} .(\mathrm{g} \mathrm{DW} \cdot \mathrm{h})^{-1}\right]$ & 1,10 & 1,10 & 0 \\
\hline$\left.q_{\mathrm{s}}[\mathrm{mmol} \text { GLC eq. (g DW.h })^{-1}\right]$ & 5,29 & 7,20 & 33 \\
\hline
\end{tabular}

\subsubsection{Fisiologia das linhagens iSUC2 ura-e SUC2 ura- em quimiostatos limitados por sacarose ou glicose em aero- ou anaerobiose}

Para verificar experimentalmente e de forma quantitativa se os parâmetros fisiológicos da levedura $S$. cerevisiae seriam alterados conforme as previsões teóricas apresentadas no item acima, a linhagem iSUC2 ura-, uma linhagem haplóide derivada da família CEN.PK (van Dijken et al., 2000), que tem o gene SUC2 modificado de forma que as células expressam apenas a forma intracelular da invertase sob controle do promotor forte $\mathrm{P}_{A D H 1}$ (Stambuk et al., 2009), foi avaliada. Como linhagem referência, utilizou-se a linhagem isogênica S. cerevisiae SUC2 ura- (CEN.PK113-5D), a qual, igualmente à linhagem iSUC2 ura-, é auxotrófica para a uracila. No entanto, esta última não tem o metabolismo de sacarose modificado, ou seja, tem o gene SUC2 selvagem, apresentando a invertase extracelular como via principal de hidrólise da sacarose (ver item 1). Ambas as linhagens foram cultivadas em quimiostatos limitados por sacarose ou glicose, sob aero- ou anaerobiose, e operados a uma vazão específica $(D)$ de $0,10 \mathrm{~h}^{-1}$. Tais cultivos foram conduzidos empregando-se meio sintético totalmente definido, contendo glicose ou sacarose como única fonte de carbono. Todos os resultados apresentados e discutidos a seguir referem-se a amostras coletadas durante o estado estacionário destes cultivos. 
A

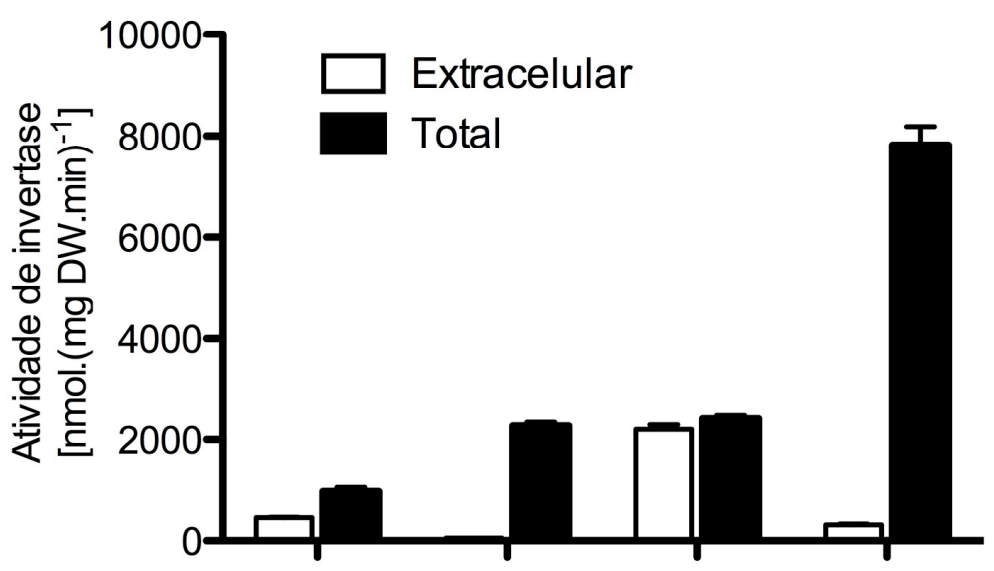

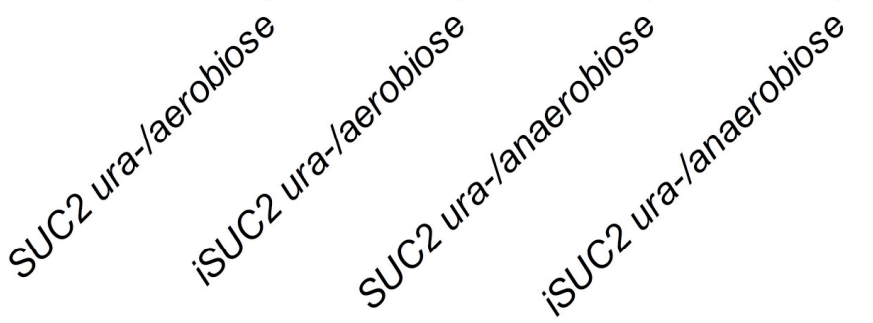

B

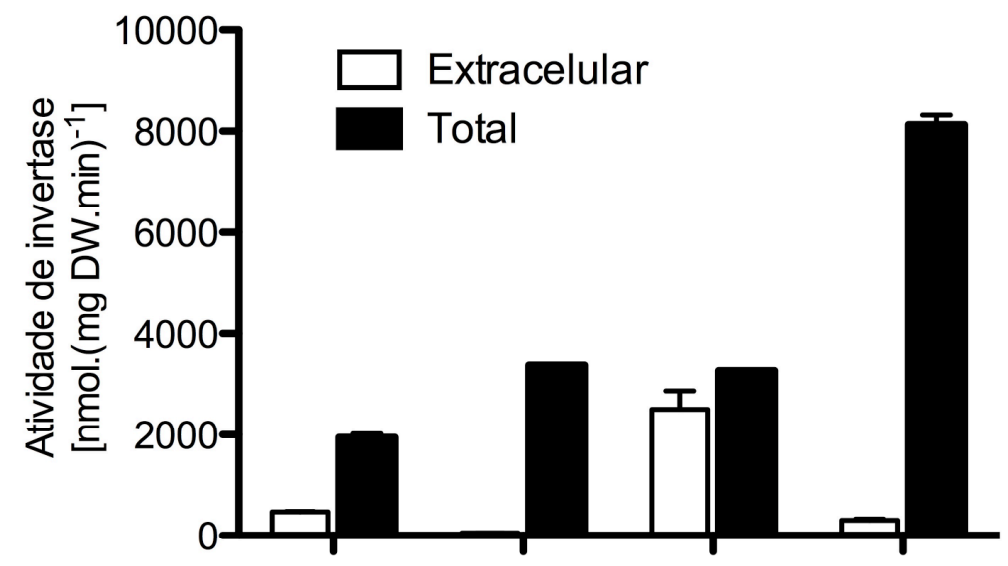

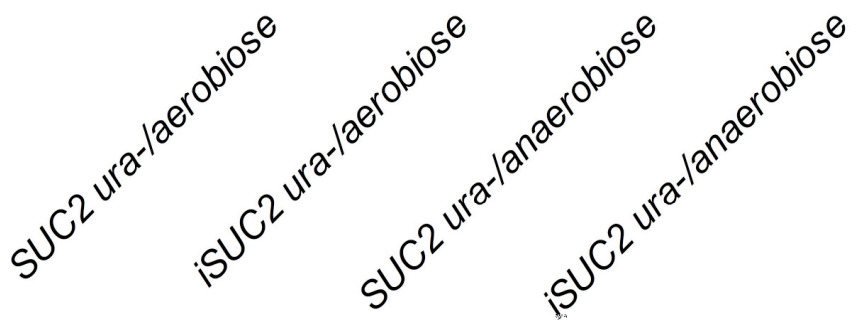

Figura 5.1 - Atividade de invertase nas linhagens SUC2 ura- e iSUC2 ura-. A atividade de invertase extracelular foi estimada com células intactas (barras brancas) e a atividade total (barras pretas) com células permeabilizadas, ambas coletadas durante o estado-estacionário de quimiostatos limitados por sacarose (A) ou glicose (B) em regime de aerobiose e anaerobiose. Os valores apresentados são as médias e os desvios-padrão de análises realizadas em triplicata, para cada duplicata biológica 
Nos cultivos limitados por sacarose com a linhagem iSUC2 ura-, a atividade de invertase foi representada quase que exclusivamente pela atividade intracelular, a qual pode ser calculada pela diferença entre a atividade total e extracelular. A atividade intracelular representou $96 \%$ da atividade total em anaerobiose e 98\% em aerobiose (Figura 5.1 A). Com isto, verificou-se que a estratégia de engenharia metabólica empregada por Stambuk, et al. (2009) resultou na retenção da atividade da invertase no ambiente intracelular na linhagem iSUC2 ura-. Além disto, nota-se que o valor absoluto da atividade de invertase é maior na linhagem iSUC2 ura-, do que na linhagem SUC2 ura-. Por outro lado, na linhagem-referência (SUC2 ura-) foram detectadas atividades para as duas formas desta enzima, sendo a forma extracelular responsável pela maior parte da atividade total nos cultivos anaeróbios (91\%), e por cerca da metade nos cultivos aeróbios (48\%). Este último dado sugere que durante o metabolismo respiratório possa existir repressão na expressão da invertase extracelular.

Foi observado que a linhagem iSUC2 ura- apresentou alguma atividade de invertase extracelular, o que não era esperado. No entanto, como o método de quantificação de invertase extracelular baseia-se na dosagem de glicose presente no meio extracelular (ver Materiais e Métodos), não se pode descartar a hipótese de que os produtos de hidrólise da sacarose (glicose e frutose), mesmo sendo hidrolisada intracelularmente, sejam excretados pelas células através dos transportadores Hxtp (Boles e Hollemberg, 1997) e detectados no sobrenadante. Assim, esta atividade "residual" extracelular pode ser uma falha da metodologia de dosagem de invertase, a qual pode ainda ser acentuada pela superexpressão da invertase intracelular nesta linhagem e pelo uso de $\mathrm{NaF}$, substância utilizada para bloquear a via glicolítica e impedir que os produtos da hidrólise da sacarose sejam consumidos nesta via metabólica.

Nos quimiostatos anaeróbicos limitados por sacarose (Tabela 5.3), o $\mathrm{Y}_{\mathrm{ETH} / \mathrm{s}}$ da linhagem iSUC2 ura- foi 5\% maior do que o mesmo parâmetro na linhagem SUC2 ura-. Em relação à $q_{\mathrm{ETH}}$, observou-se um aumento de $22 \%$ em relação à linhagem-referência (SUC2 ura-). Adicionalmente, o $Y_{X / S}$ foi cerca de $13 \%$ menor na linhagem expressando apenas a forma intracelular da invertase. Estes resultados indicam que a estratégia de engenharia metabólica, que teve o intuito de relocalizar o metabolismo da sacarose, resultou num aumento do $\mathrm{Y}_{\mathrm{ETH} / \mathrm{S}}$, fruto da menor eficiência energética das células que não expressam a invertase extracelular e se vêem obrigadas a transportar a sacarose por transporte ativo. 
Observa-se também, pelos dados apresentados na Tabela 5.3, que as concentrações de sacarose, glicose e frutose residuais foram diferentes para as duas linhagens, sendo a soma dos açúcares residuais 10 vezes superior na linhagem iSUC2 ura-, em relação à linhagem-referência (SUC2 ura-). Mesmo tendo uma atividade de invertase total muito superior à da linhagem controle (Figura 5.1), a linhagem iSUC2 ura- não foi capaz de consumir parte da fonte de carbono disponível (cerca de $8 \% \mathrm{p} / \mathrm{p}$ ). O fato de uma parte substancial da fonte de carbono não ter sido consumida pela linhagem iSUC2 ura- indica uma possível limitação no transporte deste dissacarídeo.

Nos quimiostatos limitados por sacarose em aerobiose (Tabela 5.3), foi observado que o metabolismo das duas linhagens foi completamente respiratório. $O Y_{x / s}$ foi cerca de 13 \% menor na linhagem iSUC2 ura- em relação à linhagem- referência (SUC2 ura-), analogamento ao que ocorreu nos experimentos em anaerobiose. Os valores de $q_{\mathrm{cO} 2}$ e $q_{02}$ foram maiores na linhagem iSUC2 ura- em relação à linhagem-referência, indicando uma intensificação do metabolismo nesta linhagem, provavelmente fruto da sua menor eficiência energética (geração de ATP por mol de sacarose consumida). No entanto, não era esperada uma diminuição tão acentuada (de 13\%) no $Y_{x / s}$ para os cultivos em aerobiose, pois no metabolismo puramente respiratório são gerados $76 \mathrm{~mol}$ de ATP por mol de sacarose metabolizada, e apenas $1 \mathrm{~mol}$ de ATP por mol de proton é gasto no bombeamento de protons para fora das células, no caso da linhagem iSUC2 ura-. Assim, a diferença na produção de ATP entre a linhagem iSUC2 ura- e a linhagem SUC2 ura-, deveria ser de apenas 1,2\%. Talvez a diferença no $Y_{X / S}$ seja resultado de outros processos metabólicos que foram afetados pela estratégia da engenharia metabólica empregada, mas experimentos/determinações adicionais seriam necessários para elucidar esta questão. 
Tabela 5.3 - Parâmetros fisiológicos das linhagens SUC2 ura- (referência) e iSUC2 ura- (ausência de invertase extracelular e super-expressão da invertase intracelular) durante o estado estacionário em quimiostatos limitados por sacarose ou glicose em aero- ou anaerobiose. Os dados estão apresentados como a média e \pm o desvio da média de dois experimentos independentes.

\begin{tabular}{|c|c|c|c|c|c|c|c|c|c|c|c|}
\hline \multirow{3}{*}{ Parâmetros Fisiológicos } & \multicolumn{4}{|c|}{ Sacarose } & \multirow{3}{*}{$\begin{array}{l}\text { iSUC2/ } \\
\text { SUC2 } \\
(\%)^{(a)}\end{array}$} & \multicolumn{6}{|c|}{ Glicose } \\
\hline & \multicolumn{2}{|c|}{ Aerobiose } & \multicolumn{2}{|c|}{ Anaerobiose } & & \multicolumn{3}{|c|}{ Aerobiose } & \multicolumn{3}{|c|}{ Anaerobiose } \\
\hline & SUCZ ura & isUC2 ura & SUC2 ura & iSUC2 ura & & $\begin{array}{c}\text { CEN.PK11 } \\
\text { 3-7D }^{(\mathbf{b})}\end{array}$ & $\begin{array}{c}\text { SUC2 } \\
\text { ura }\end{array}$ & $\begin{array}{c}\text { iSUC2 } \\
\text { ura }\end{array}$ & $\begin{array}{c}\text { CEN.PK11 } \\
3-7 D^{(c)}\end{array}$ & $\begin{array}{l}\text { SUC2 } \\
\text { ura }\end{array}$ & $\begin{array}{l}\text { iSUC2 } \\
\text { ura }\end{array}$ \\
\hline$D\left(\mathrm{~h}^{-1}\right)$ & $0,103 \pm 0,005$ & $0,093 \pm 0,001$ & $0,102 \pm 0,003$ & $0,103 \pm 0,005$ & & 0,10 & 0,100 & 0,097 & 0,10 & 0,106 & 0,107 \\
\hline Glicose $\left(g \cdot L^{-1}\right)$ & $0,036 \pm 0,005$ & $0,010 \pm 0,002$ & $0,047 \pm 0,006$ & $0,090 \pm 0,028$ & & 0,03 & 0,030 & 0,027 & 0,08 & 0,069 & 0,06 \\
\hline Frutose $\left(\mathrm{g} \cdot \mathrm{L}^{-1}\right)$ & $0,062 \pm 0,014$ & $0,017 \pm 0,003$ & $0,103 \pm 0,016$ & $0,053 \pm 0,033$ & & & & & & & \\
\hline Sacarose (g GLC eq. $\left.\mathrm{L}^{-1}\right)^{(\mathrm{d})}$ & 0 & $0,031 \pm 0,001$ & 0 & $2,81 \pm 0,07$ & & & & & & & \\
\hline$Y_{x / s}\left(g\right.$ DW.g GLC eq- $\left.{ }^{1}\right)$ & $0,539 \pm 0,003$ & $0,47 \pm 0,007$ & $0,109 \pm 0,001$ & $0,095 \pm 0,003$ & $-13 /(-25)$ & 0,5 & 0,504 & 0,494 & 0,10 & 0,103 & 0,104 \\
\hline$\left.q_{\mathrm{s}}[\mathrm{mmol} \text { GLG eq.(g DW.h })^{-1}\right]$ & $1,06 \pm 0,055$ & $1,103 \pm 0,013$ & $5,178 \pm 0,199$ & $6,003 \pm 0,121$ & $16 /(33)$ & & 1,103 & 1,092 & & 5,708 & 5,742 \\
\hline$q_{\mathrm{CO} 2}\left[\mathrm{mmol} .(\mathrm{g} \text { DW.h. })^{-1}\right]$ & $2,47 \pm 0,47$ & $3,38 \pm 0,04$ & $8,67 \pm 0,13$ & $10,7 \pm 0$ & $23 /(40)$ & 2,8 & 2,65 & 2,59 & 8,7 & 8,93 & 8,88 \\
\hline$q_{02}\left[\mathrm{mmol} .(\mathrm{g} \mathrm{DW} . \mathrm{h})^{-1}\right]$ & $2,22 \pm 0,21$ & $3,11 \pm 0,04$ & 0 & 0 & & 2,6 & 2,25 & 2,22 & 0 & 0 & 0 \\
\hline $\mathrm{RQ}$ & $1,11 \pm 0,11$ & $1,09 \pm 0$ & & & & 1,08 & 1,18 & 1,17 & & & \\
\hline$Y_{\text {ETH/S }}\left(g\right.$ ETH.g GLC eq $\left.{ }^{-1}\right)$ & 0 & 0 & $0,363 \pm 0,005$ & $0,382 \pm 0,004$ & $5 /(8)$ & & 0 & 0 & & 0,379 & 0,389 \\
\hline$q_{\text {ETH }}\left[\right.$ mmol..$\left.(\mathrm{g} \text { DW.h.h })^{-1}\right]$ & 0 & 0 & $7,34 \pm 0,19$ & $8,97 \pm 0,27$ & $22 /(43)$ & 0 & 0 & 0 & 0 & 8,45 & 8,72 \\
\hline$q_{\text {ACE }}\left[\mathrm{mmol} .(\mathrm{g} \mathrm{DW} \cdot \mathrm{h})^{-1}\right]$ & 0 & 0 & 0 & 0 & & & 0 & 0 & & 0 & 0 \\
\hline$q_{\mathrm{LAC}}\left[\mathrm{mmol} .(\mathrm{g} \text { DW.h })^{-1}\right]$ & 0 & 0 & $0,065 \pm 0,008$ & $0,075 \pm 0,015$ & & & 0 & 0 & & 0,085 & 0,093 \\
\hline$q_{\mathrm{PYR}}\left[\mathrm{mmol} .(\mathrm{g} \text { DW.h. })^{-1}\right]$ & 0 & 0 & $0,011 \pm 0,001$ & $0,014 \pm 0,003$ & & & 0 & 0 & & 0,013 & 0,013 \\
\hline$q_{\text {succ }}\left[\mathrm{mmol} .(\mathrm{g} \mathrm{DW} . \mathrm{h})^{-1}\right]$ & 0 & 0 & $0,001 \pm 0$ & $0,001 \pm 0$ & & & 0 & 0 & & 0,002 & 0,002 \\
\hline$q_{\mathrm{GLYC}}\left[\mathrm{mmol} .(\mathrm{g} \text { DW.h })^{-1}\right]$ & 0 & 0 & $0,607 \pm 0,067$ & $0,709 \pm 0,062$ & $17 /(0)$ & & 0 & 0 & & 0,810 & 0,786 \\
\hline Balanço de Carbono $(\%)^{(\mathrm{e})}$ & $98 \pm 5$ & $103 \pm 2$ & $94 \pm 1$ & $97 \pm 1$ & & & 95,5 & 93,9 & & 95,1 & 96 \\
\hline FC $\left.[\mathrm{mmol} \text { ETH.(g DW.h })^{-1}\right]$ & $8,6 \pm 0,6$ & $6,0 \pm 1,8$ & $10,6 \pm 2,1$ & $11,9 \pm 4,4$ & & 7,6 & nd & nd & 14,8 & 6,1 & 7,6 \\
\hline
\end{tabular}


Diferentemente do cultivo limitado por sacarose em anaerobiose, as concentrações de sacarose, glicose e frutose residuais foram bem mais baixas no cultivo aeróbico com a linhagem iSUC2 ura-. Adicionalmente, foi constatado que a concentração de sacarose residual nos cultivos em aerobiose com a linhagem iSUC2 ura- $\left(0,031 \mathrm{~g} \mathrm{GLC}\right.$ eq. $\left.\mathrm{L}^{-1}\right)$ foi bastante próxima da concentração de maltose residual $\left(0,025 \mathrm{~g} \mathrm{GLC}\right.$ eq. $\left.\mathrm{L}^{-1}\right)$ durante 0 estado-estacionário de cultivos aeróbicos limitados por este dissacarídeo (Jansen et al., 2004). Cabe destacar que a maltose também é transportada pelo co-transporte com $\mathrm{H}^{+}$. Assim, parece que a afinidade por sacarose dos transportadores na linhagem iSUC2 ura-é alta, uma vez que a concentração do substrato residual no quimiostato é inversamente proporcional à afinidade do transportador pelo substrato limitante (Jansen et al., 2004).

Estas observações parecem descartar a hipótese de que a alta concentração de sacarose residual $\left(2,8 \mathrm{~g} \mathrm{GLC}\right.$ eq. $\left.\mathrm{L}^{-1}\right)$, observada no cultivo em anaerobiose com a linhagem iSUC2 ura-, seja resultado de uma baixa afinidade do(s) transportadore(s) pela sacarose, devido a uma constante de saturação pelo substrato $\left(K_{\mathrm{m}}\right)$ elevada. Como a afinidade específica dos transportadores pelo substrato limitante pode ser definida com $q_{\mathrm{s}} . K_{m}{ }^{-1}$, onde

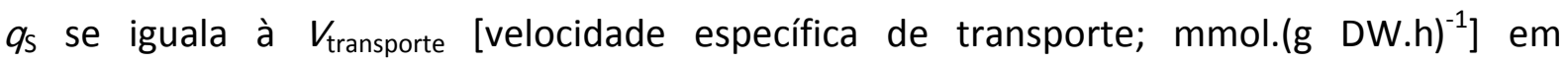
quimiostatos (Button, 1991; Jansen et al., 2004), torna-se plausível sugerir que a baixa afinidade específica observada no cultivo em anaerobiose limitado por sacarose seja uma limitação na $V_{\text {transporte }}$ da linhagem iSUC2 ura-, ou seja, na capacidade de transporte de sacarose $\left(V_{\max }\right)$.

De uma maneira geral, os parâmetros fisiológicos observados nos cultivos com a linhagem-referência (SUC2 ura-) foram semelhantes aos obtidos por Barford et al. (1995), ao analisarem a linhagem de panificação de S. cerevisiae 248 UNSW 703100. De fato, estes são, para o nosso conhecimento, os únicos dados publicados na literatura científica para cultivos contínuos limitados por sacarose em meio de cultura definido.

Com o intuito de verificar se as diferenças obtidas entre as duas linhagens seriam exclusivas aos cultivos limitados por sacarose, foi realizada uma série de experimentos idênticos, porém sob limitação de glicose. Os dados obtidos demonstram que praticamente não houve diferenças entre as linhagens nestas condições (Tabela 5.3), o que é muito interessante, pois o objetivo da estratégia de engenharia metabólica empregada era o de modificar somente o metabolismo do dissacarídeo sacarose, no sentido de aumentar a 
formação de etanol quando as células são cultivadas nesta fonte de carbono, que é a situação relevante na atual produção industrial de etanol brasileira. Portanto, aparentemente, as modificações genéticas realizadas não afetaram outros aspectos da fisiologia destas células, o que é desejável.

Em relação às atividades de invertase nos cultivos com glicose com as duas linhagens (Figura 5.1 B), os resultados observados foram muito semelhantes aos cultivos em sacarose. No caso da linhagem SUC2 ura-, a atividade extracelular foi responsável pela maior parte da atividade total (76\%) nos cultivos anaeróbios, mas em contrapartida, por apenas $24 \%$ nos cultivos aeróbios. No caso dos cultivos com a linhagem iSUC2 ura-, a atividade de invertase foi representada quase que exclusivamente pela atividade intracelular ( $96 \%$ em anaerobiose, e $98 \%$ em aerobiose). É sabido que a atividade de invertase extracelular é reprimida pela presença de glicose (Carlson e Botstein, 1982; Mwesigye e Barford, 1996). No entanto, nos cultivos em glicose, a atividade de invertase extracelular na linhagem referência foi semelhante aos valores obtidos em sacarose. Provavelmente, a concentração de glicose é baixa o suficiente (Tabela 5.3) para não reprimir a expressão do gene SUC2, sendo até mesmo capaz de induzir sua expressão nestas concentrações, como reportado por Ozcan et al., 1997.

Os dados de transporte, utilizando $\left[\mathrm{U}-{ }^{14} \mathrm{C}\right]$ sacarose a $20 \mathrm{mM}$, são apresentados na Figura 5.2. Primeiramente, é preciso ressaltar que a concentração de sacarose utilizada nesta medida não foi muito maior do que o valor de $K_{m}$ reportado para o transporte de sacarose pelo Agt1p (8 mM). Além disto, a concentração utilizada foi bem menor do que o $K_{m}$ para os transportadores Malx1p (120 mM) (Stambuk et al., 2000). Portanto, os dados de transporte não devem ser interpretados como sendo referentes à capacidade máxima de transporte $\left(V_{\max }\right)$ de sacarose nas linhagens estudadas. É possível observar, por exemplo, que o $q_{\mathrm{s}}$ da linhagem iSUC2 ura- em cultivos anaeróbicos limitados por sacarose, que foi de $6,0 \mathrm{mmol}$ GLC eq.(g DW.h) ${ }^{-1}$ (Tabela 5.3), equivalente a 52,5 nmol SUC.(mg DW.min) ${ }^{-1}$. Se esta linhagem metaboliza toda a sacarose através do seu transporte ativo, o $V_{\text {transporte }}$ deveria ser no mínimo igual ou superior ao valor de $q_{s}$. No entanto, o $V_{\text {transporte }}$ encontrado foi de apenas 5 nmol SUC.(mg DW.min) ${ }^{-1}$ (Figura 5.2).

De uma forma geral, os valores de transporte obtidos com as células crescendo em sacarose foram muito próximos aos obtidos com as células crescendo em glicose. A única exceção foi com a linhagem iSUC2 ura-, para a qual a atividade de transporte foi maior no 
cultivo aeróbico limitado por sacarose do que no cultivo limitado por glicose. Estes dados reforçam a hipótese de que a sacarose não funciona como molécula indutora dos transportadores Malx1p e Agt1p, diferentemente do que ocorre com a maltose (Batista et al., 2004).

Nos cultivos limitados por sacarose em anaerobiose, foi observado que o transporte de sacarose marcada foi menor na linhagem iSUC2 ura- do que na linhagem SUC2 ura-. Por outro lado, nos cultivos limitados por sacarose em aerobiose, o transporte de sacarose marcada foi maior na linhagem iSUC2 ura- do que na linhagem SUC2 ura-. É provável que estes resultados sejam decorrentes das diferentes concentrações de glicose no estadoestacionário destes cultivos, uma vez que a glicose reprime a expressão dos transportadores e promove inativação catabólica dos mesmos (Medintz et al., 1996). A concentração de glicose foi maior nos cultivos em anaerobiose com a linhagem iSUC2 ura- em relação a linhagem SUC2 ura-, e menor nos cultivos em aerobiose com a linhagem iSUC2 ura- em relação a linhagem SUC2 ura- (Tabela 5.3). No entanto, as diferenças nos teores de glicose dos cultivos limitados por glicose não explicam os dados de transporte, os quais foram distintos entre as duas linhagens. Contudo, é intrigante observar que nos cultivos anaeróbios limitados por sacarose, o transporte foi menor na linhagem iSUC2 ura- do que na linhagemreferência (SUC2 ura-). Mwesigye e Barford (1994) reportaram $V_{\max }$ ao redor de $20 \mathrm{nmol} .(\mathrm{mg}$ DW.min $)^{-1}$, utilizando $\left[\mathrm{U}^{14} \mathrm{C}\right]$ sacarose a uma concentração de $13 \mathrm{mM}$.

Para concluir, cabe ressaltar que a estratégia de engenharia metabólica desenvolvida por Stambuk et al. (2009), avaliada aqui de forma quantitativa, apesar de algumas limitações encontradas (concentração de açúcares residuais elevada e parâmetros fisiológicos diferentes dos previstos pelo modelo), pode ser considerada bastante promissora, pois trabalhos que buscaram aumentar o rendimento em etanol pelo incremento no consumo de ATP na biossíntese celular resultaram num aumento de apenas $3 \%$ (bastante questionável do ponto de vista estatístico, conforme os próprios autores indicam) no parâmetro $\mathrm{Y}_{\mathrm{ETH} / \mathrm{s}} \mathrm{em}$ relação à levedura referência (Bro et al., 2006). Outra estratégia, obtida pela modificação do metabolismo de glutamato, resultou em cerca de $10 \%$ de aumento no $\mathrm{Y}_{\mathrm{ETH} / \mathrm{S}}$ (Nissen et al., 2000). No entanto, para o sucesso desta última estratégia, as células necessitam assimilar nitrogênio na forma de $\mathrm{NH}_{4}{ }^{+}$, o que não é uma realidade em substratos industriais, nos quais as fontes de $\mathrm{N}$ são normalmente aminoácidos. 
A

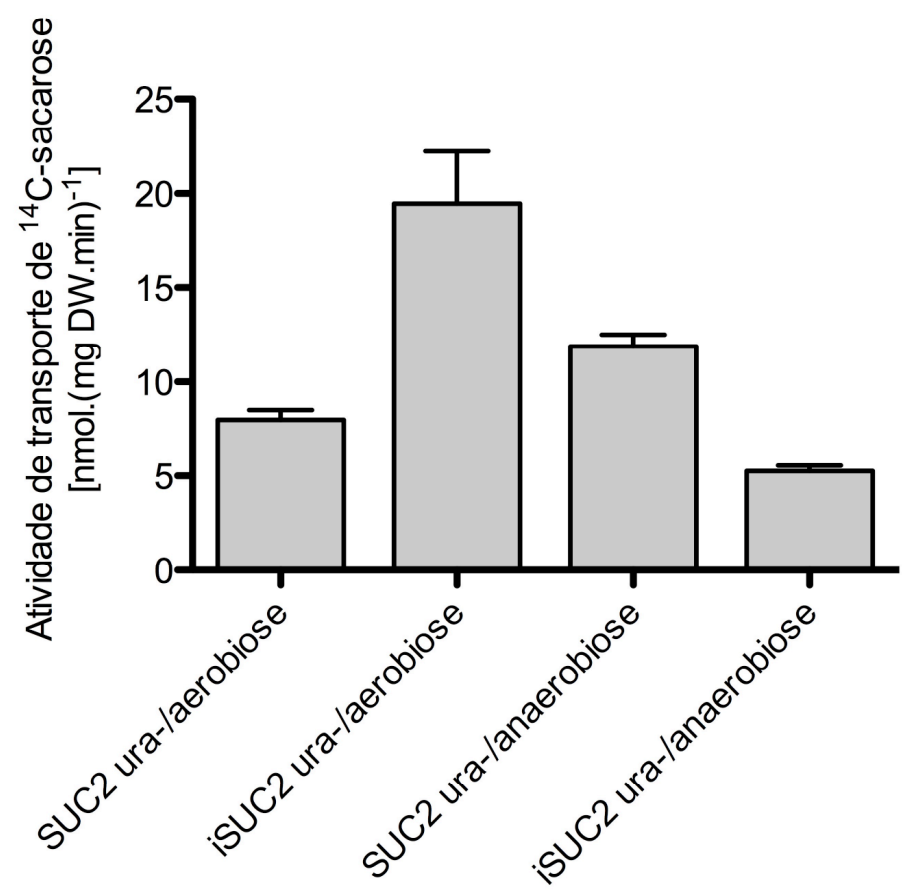

B

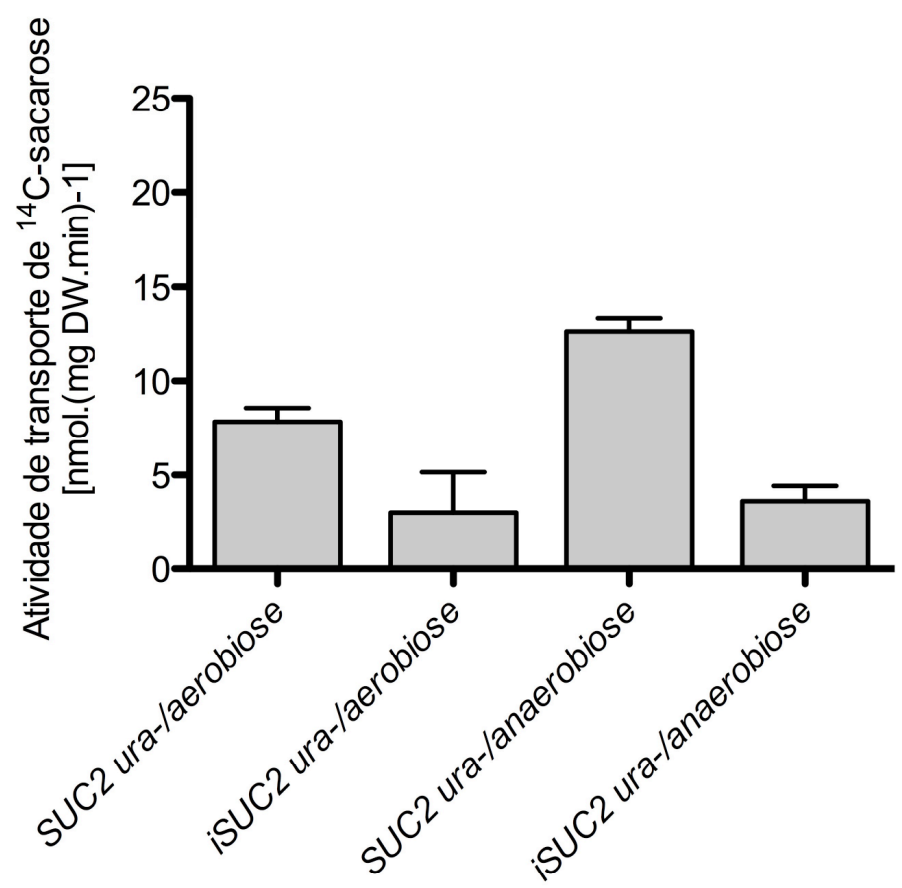

Figura 5.2 - Atividade de transporte de $\left[\mathrm{U}^{14} \mathrm{C}\right]$ sacarose nas linhagens SUC2 ura-e iSUC2 ura-. A atividade de transporte foi estimada nas células coletadas durante o estado-estacionário de quimiostatos limitados por sacarose (A) ou por glicose (B) em aerobiose e anaerobiose, conforme descrito na parte de Materiais e Métodos. Os valores apresentados são as médias e os desvios-padrão de análises realizadas em triplicata, para cada duplicata biológica. 


\subsection{Comparação das linhagens SUC2 e iSUC2 em cultivos descontínuos}

\subsubsection{Cultivos descontínuos em frasco agitado}

No presente estudo, foram levantados diversos dados fisiológicos em cultivos contínuos (item 5.2). Estes dados mostraram diferenças significativas em muitos parâmetros fisiológicos entre as linhagens iSUC2 ura- e SUC2 ura-, e assim, permitiram quantificar algumas das implicações fisiológicas provenientes da relocalização do metabolismo da sacarose na levedura $S$. cerevisiae. Apesar de altamente quantitativos, nos quimiostatos os dados são obtidos com as linhagens crescendo na mesma velocidade específica de crescimento (a qual foi relativamente baixa, $\mu$ de $0,10 \mathrm{~h}^{-1}$ ) e em condições na qual a concentração de açúcar é geralmente baixa. Desta maneira, decidiu-se investigar o efeito da modificação do gene SUC2 sobre o $\mu_{\max }$ e sobre outros parâmetros fisiológicos, durante o crescimento em cultivos descontínuos, nos quais a fonte de carbono encontra-se em excesso. Mais especificamente, as linhagens SUC2 ura- e iSUC2 ura- foram cultivadas em modo descontínuo (frasco agitado) com meio sintético.

Nos cultivos realizados com sacarose como fonte de carbono (Figura 5.3), houve uma diferença significativa nos valores de $\mu_{\max }$ entre as duas linhagens. $O$ referido parâmetro foi de 0,40 $\pm 0,01 \mathrm{~h}^{-1}$ na linhagem-referência (SUC2 ura-), sendo assim próximo ao publicado na literatura com a linhagem diplóide CEN.PK122 nas mesmas condições $\left(0,38 \mathrm{~h}^{-1}\right.$; van Dijken et al., 2000). No caso da linhagem iSUC2 ura-, o $\mu_{\max }$ foi consideravelmente menor $(0,25 \pm 0,01$ $\mathrm{h}^{-1}$ ). Uma constatação surpreendente nos cultivos com a linhagem modificada foi a ausência de etanol e glicerol no meio de cultivo durante o crescimento desta linhagem, o que indica um metabolismo puramente respiratório. Provavelmente, o crescimento lento desta linhagem, abaixo do valor da vazão específica crítica em $S$. cerevisiae linhagem CEN.PK1137D $\left(0,30 \mathrm{~h}^{-1}\right.$; van Hoek et al., 1998), tenha permitido a utilização da sacarose exclusivamente pela via respiratória. Em concordância com tal observação, constatou-se um maior rendimento de biomassa sobre substrato (maior $\mathrm{Abs}_{600}$ ao atingir-se a exaustão da fonte de carbono) da linhagem iSUC2 ura- em relação à linhagem-referência. Uma possível causa para este fenótipo diferente da linhagem iSUC2 ura-seria uma baixa capacidade de transporte de sacarose, o que restringiria o fluxo de carbono pela via glicolítica, permitindo que o mesmo 
fosse totalmente direcionado para as vias respiratórias. No entanto, como não foram levantados dados sobre a capacidade de transporte de sacarose durante estes cultivos, não se pode precisar se o crescimento lento é resultado de um transporte de sacarose limitante na linhagem iSUC2 ura-.
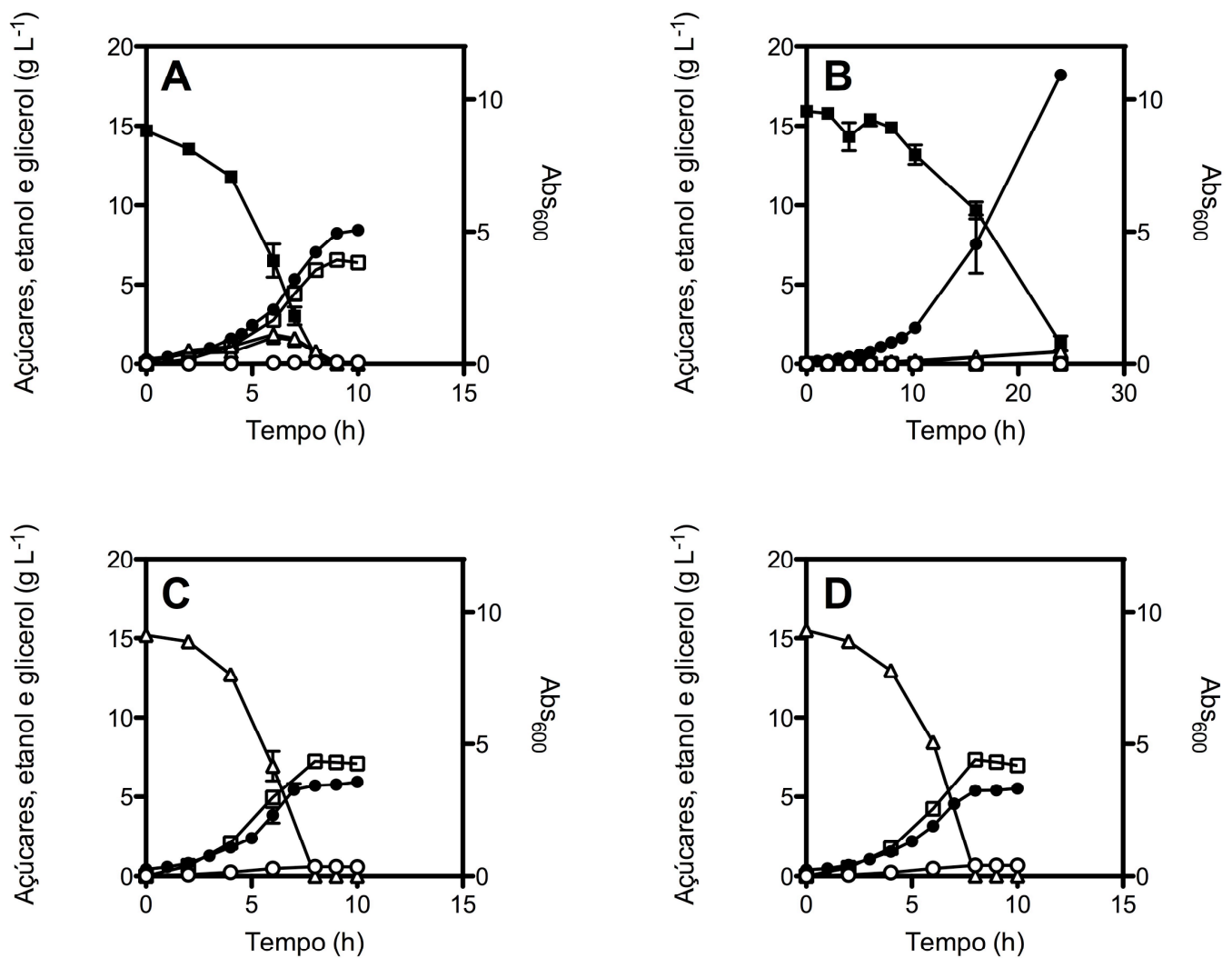

Figura 5.3 - Cultivos descontínuos (em frasco agitado) com as linhagens SUC2 ura- (A, C) e iSUC2 ura- (B, D). Concentração celular $(\bullet)$, concentração de sacarose $(\boldsymbol{\square})$, glicose $(\triangle)$ e frutose $(\mathbf{A})$, e concentração de etanol $(\square)$ e glicerol $(O)$ durante o cultivo em meio sintético com uréia, suplementados com uracila, e contendo sacarose (A, B) ou glicose (C, D) a 15 g. L $^{-1}$ iniciais como fonte exclusiva de carbono e energia. Os dados são apresentados como a média \pm desvio dao media de experimentos independentes realizados em duplicata.

Diferentemente dos cultivos com a linhagem iSUC2 - ura, nos cultivos em sacarose com a linhagem-referência (SUC2 ura-), houve formação de etanol (Figura 5.3 A), e assim o $Y_{X / S}$ foi semelhante (dados não apresentados) aos cultivos contínuos anaeróbicos limitados por sacarose (Tabela 5.3). Como a glicose é apontada como causadora de repressão nas enzimas respiratórias (Fiechter et al., 1981), torna-se plausível especular que uma outra razão para um metabolismo puramente respiratório nos cultivos com a linhagem iSUC2 uraem sacarose, seja a ausência de glicose durante tais cultivos. Por outro lado, nos cultivos em 
sacarose com a linhagem-referência, observou-se acúmulo de glicose no meio $\left(3 \mathrm{~g} \mathrm{~L}^{-1}\right)$, o que pode ter contribuído para um metabolismo respiro-fermentativo nesta situação.

Cabe ressaltar que nestes cultivos em frasco agitado tipo erlenmeyer, existe transferência de oxigênio do ar para o meio de cultura, de maneira que os cultivos ocorreram em situação de aerobiose plena, eventualmente com instantes de limitação por oxigênio (não é possível garantir que houve aerobiose plena durante todo o tempo de cultivo, pois não se mediu a concentração de oxigênio dissolvido). Isto é diferente da situação de anaerobiose total em que os quimiostatos foram realizados (item 5.2), não havendo, naqueles experimentos, possibilidade de ocorrência de respiração.

Ao estudarem o crescimento em sacarose de uma linhagem incapaz de transportar hexoses (e assim obrigada a transportar o dissacarídeo), Batista et al. (2004) reportaram que, somente com a expressão constitutiva do gene $M A L 63^{\complement}$, que codifica a proteína de regulação positiva dos genes $M A L$, foi possível que a levedura crescesse em meio sintético com sacarose (sendo que $\circ \mu_{\max }$ foi de $0,12 \pm 0,01 \mathrm{~h}^{-1}$ ). Este mesmo grupo de pesquisa reportou que $o \mu_{\max }$ em meio rico com sacarose numa linhagem obrigada a transportar sacarose por uma outra estratégia ( $\Delta$ suc2), foi de $0,24 \pm 0,01 \mathrm{~h}^{-1}$ (Badotti et al., 2008). No entanto, diferentemente dos resultados observados no presente estudo, em que não houve formação de etanol, os dois estudos citados relataram a presença de etanol no meio de cultivo, mesmo com valores de $\mu_{\max }$ menores do que o valor critico $\left(0,30 \mathrm{~h}^{-1}\right)$.

Cabe aqui ressaltar que não foram observadas diferenças significativas nos valores de $\mu_{\max }$ entre as duas linhagens quando cultivadas em meio sintético com glicose, tendo sido obtidos valores de 0,37 $\pm 0,01 \mathrm{~h}^{-1}$ e 0,38 $\pm 0,00 \mathrm{~h}^{-1}$ para as linhagens SUC2 ura-e iSUC2 ura-, respectivamente. Na verdade, estes cultivos foram praticamente idênticos entre si. Não foram observadas diferenças significativas entre os $Y_{x / S}$ das duas linhagens $(0,16 \pm 0,01$, para SUC2 ura-; e 0,16 $\pm 0,01 \mathrm{~g}$ DW.g ${ }^{-1}$ para iSUC2 ura-), bem como do $\mathrm{Y}_{\mathrm{ETH} / \mathrm{S}}(0,45 \pm 0,01$, para SUC2 ura-; e 0,44 $\pm 0,01 \mathrm{~g}^{-\mathrm{g}^{-1}}$ para iSUC2 ura-). Com isto, pode-se inferir que a modificação no gene SUC2 na linhagem iSUC2 ura- não interferiu no metabolismo da glicose, corroborando os dados obtidos nos cultivos contínuos (ver item 5.2).

Outra observação interessante é que quando a linhagem prototrófica CEN.PK113-7D foi cultivada nas mesmas condições, tendo glicose como fonte de carbono, o $\mu_{\max }(0,37 \pm$ $0,00 \mathrm{~h}^{-1}$ ) desta linhagem não diferiu da linhagem controle SUC2 ura-, auxotrófica para a uracila (dados não apresentados). Isto é um forte indicativo de que, apesar das linhagens 
empregadas neste estudo (até este momento) serem auxotróficas para a uracila, este fato não representa um fator limitante para a interpretação dos resultados. Apesar dos cultivos conduzidos em meio sintético suplementado com uracila não apresentarem diferenças entre as linhagens auxotróficas e prototróficas, o mesmo não ocorreu nos cultivos em meio rico complexo (YPD). Nestes cultivos, foram observadas diferenças no perfil de crescimento e no tempo para exaustão da fonte de carbono, entre cultivos suplementados com uracila e cultivos não suplementados (dados não apresentados), o que indica que, apesar do meio YPD ser bastante rico e complexo, não há uracila em quantidade suficiente para suplementar a necessidade auxotrófica da linhagem SUC2 ura-, conforme recentemente apontado por Corbacho et al., 2010.

\subsubsection{Cultivos descontínuos em anaerobiose plena}

Neste ponto dos trabalhos, decidiu-se eliminar a auxotrofia por uracila na linhagem iSUC2 ura- (BSY021-34B). Para esta finalidade, o alelo não funcional ura3-52 foi substituído pelo gene funcional URA3 (ver Materiais e Métodos). A nova linhagem prototrófica obtida, designada iSUC2 (MATa URA3 trp1-289 TRP1 - pADH1::iSUC2 MAL2-8์ AGT1), foi então investigada em comparação à linhagem-referência CEN.PK113-7D (MATa URA3 SUC2 MAL2$\left.8^{c} A G T 1\right)$, a qual, igualmente à linhagem iSUC2, é prototrófica para a uracila, mas no entanto tem o gene SUC2 selvagem.

Em virtude da ausência de etanol nos cultivos descontínuos em frasco agitado (item 5.3.1), decidiu-se investigar a importância do transportador de sacarose na levedura modificada. Mais precisamente, optou-se por investigar o transportador de alta afinidade para a sacarose, Agt1p, (Stambuk et al., 1999, 2000) tanto na linhagem expressando apenas a invertase intracelular, iSUC2, como na linhagem controle, SUC2. Para tal, o gene AGT1 foi deletado nestas linhagens, conforme descrito no item Materiais e Métodos. As duas novas linhagens obtidas, iSUC2 $\triangle a g t 1$ e SUC2 $\triangle a g t 1$, bem como as suas parentais (iSUC2 e SUC2), foram cultivadas em regime de bateladas repetidas sob anaerobiose em meio sintético contendo sacarose como fonte exclusiva de carbono e energia. Vale destacar que optou-se por utilizar bateladas repetidas e amostrar o terceiro ciclo (ver Materiais e Métodos). A razão para tal foi anular possíveis diferenças oriundas da transferência do inóculo, cultivado 
em regime de aerobiose (em frasco agitado), para uma condição de plena anaerobiose (nos fermentadores), bem como para eliminar variações oriundas da fase de crescimento do inóculo, como já apontado por Abbott et al. (2009).

Através dos perfis de $\mathrm{CO}_{2}$ oriundos destes cultivos (Figura 5.4), nota-se que o tempo de cultivo é praticamente dobrado (de $10 \mathrm{~h}$ para $20 \mathrm{~h}$ ) ao compararmos a linhagem SUC2 (referência) com a linhagem iSUC2. No caso da linhagem iSUC2 $\triangle a g t 1$ a ausência do transportador Agt1p aumenta ainda mais o tempo de fermentação ( $35 \mathrm{~h}$ ) e parece reduzir a afinidade de captação da sacarose, principalmente ao final do cultivo (observado, de maneira indireta, pelo declínio menos acentuado no perfil de $\mathrm{CO}_{2}$ no gás de saída quando comparado às demais linhagens). Estes dados estão de acordo com a constatação de que o gene AGT1 é um transportador de alta afinidade para a sacarose (Stambuk et al., 2000; Batista et al., 2004). No entanto, tais dados não eliminam a possibilidade de que outros transportadores, possivelmente Malx1p, possam também transportar a sacarose, embora com baixa afinidade (Stambuk et al., 2000; Badotti et al., 2008). Adicionalmente, é possível especular que a ocorrência de um vazamento de invertase para fora das células e/ou a presença de alguma hidrolase extracelular estejam permitindo a hidrólise (lenta) da sacarose e o consumo dos monossacarídeos resultantes.

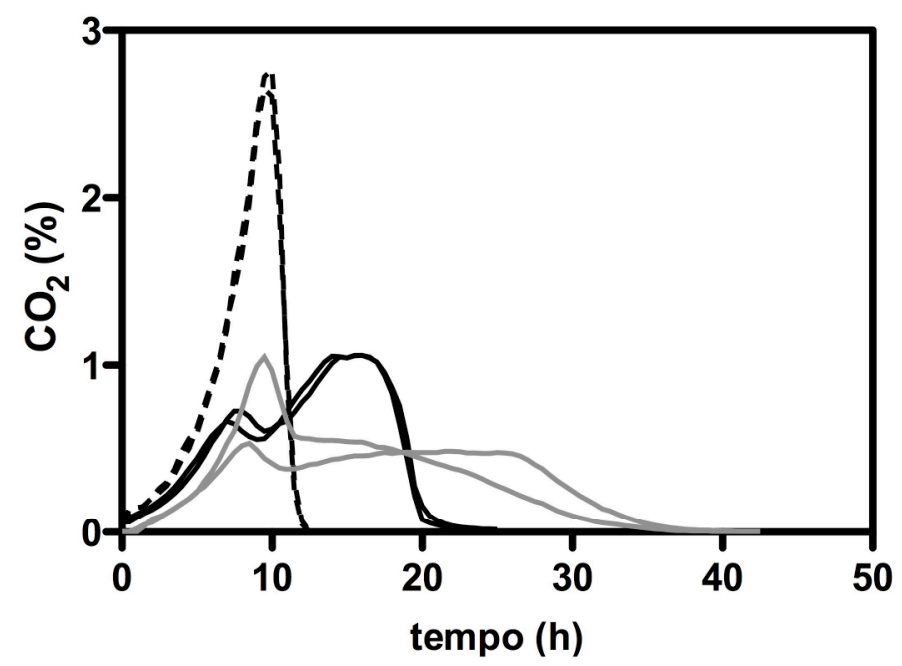

Figura 5.4 - Perfil de $\mathrm{CO}_{2}$ no gás de saída em cultivos descontínuos com as linhagens SUC2 (linhas pretas tracejadas); iSUC2 (linhas pretas sólidas); e iSUC2 $\triangle$ agt1 (linhas cinzas). Os cultivos foram conduzidos em anaerobiose plena, de forma descontínua, em meio sintético definido, contendo $20 \mathrm{~g} . \mathrm{L}^{-1}$ de sacarose iniciais como única fonte de carbono. Dois cultivos independentes para cada linhagem estão representados no gráfico 
Por outro lado, a remoção do gene $A G T 1$ na linhagem referência SUC2 não resultou em alteração no perfil de $\mathrm{CO}_{2}$, não interferindo no tempo de fermentação, quando comparado à linhagem SUC2 (dados não apresentados). Como o perfil da linhagem SUC2 $\triangle a g t 1$ é idêntico ao da linhagem SUC2 (que possui o gene $A G T 1$ ), pode-se afirmar que o transporte de sacarose numa linhagem com o gene SUC2 selvagem, ou seja, que expressa majoritariamente a invertase extracelular, não parece exercer papel essencial na metabolização deste dissacarídeo. Em outras palavras, a via extracelular de consumo de sacarose é mesmo a principal via, como afirma a literatura (Carlson e Botstein, 1982; Santos et al., 1982; Stambuk et al., 2000), apesar de alguns trabalhos sugerirem que a via intracelular pode contribuir significativamente para o metabolismo de sacarose em células selvagens de S. cerevisiae (Orlowski e Barford, 1991; Mwesigye e Barford, 1994; 1996). No entanto, nestes três trabalhos em particular, as células foram adaptadas por mais de 200 gerações em sacarose, antes do experimento e, além disto, o meio continha glicose em quantidade suficiente para reprimir a atividade de invertase extracelular.

Nos cultivos descontínuos em anaerobiose plena, ao contrário da linhagem SUC2, praticamente não houve acúmulo de glicose e frutose no meio de cultivo da linhagem iSUC2 (Figura 5.5), provavelmente devido ao transporte da sacarose e hidrólise intracelular. Enquanto a concentração de glicose e frutose nos cultivos com a linhagem SUC2 chegaram aos valores máximos de 5 e 8 g. $\mathrm{L}^{-1}$, respectivamente, as concentrações destes açucares não passaram de 1 g. L $^{-1}$ nos cultivos com a linhagem iSUC2. Similarmente aos cultivos com a linhagem-referência (SUC2), Mwesigye e Barford (1996) observaram acúmulo de frutose (4 g. $\mathrm{L}^{-1}$ ) durante cultivos descontínuos aeróbicos com sacarose (concentração inicial de $10 \mathrm{~g} . \mathrm{L}^{-1}$ ) utilizando a linhagem de $S$. cerevisae 248 UNSW 703100.

Como verificado pelo perfil de $\mathrm{CO}_{2}$, o tempo necessário para a exaustão da sacarose foi significativamente maior na linhagem iSUC2 do que na linhagem SUC2 (20 e $10 \mathrm{~h}$, respectivamente). Isto é refletido numa velocidade específica de consumo de sacarose menor na linhagem iSUC2 [11,1 \pm 0,2 mmol GLC eq.(g DW.h $\left.)^{-1}\right]$ em comparação à linhagemreferência $\left.[19,4 \pm 0,2 \mathrm{mmol} \text { GLC eq.(g DW.h })^{-1}\right]$. Este último valor foi muito próximo aos dados publicados [19 mmol GLC eq.(g DW.h) $)^{-1}$ ] por Orlowski e Barford (1991) e Mwesigye e Barford (1996), durante cultivos descontínuos aeróbicos com a linhagem S. cerevisae 248 UNSW 703100. No entanto, em ambos os trabalho citados, foram empregadas células previamente adaptadas em sacarose por cerca de 250 gerações, através de transferências 
seriadas durante 14 dias em frascos agitados com meio sintético contendo sacarose como fonte de carbono. Ainda nestes trabalhos, cultivos descontínuos com células não-adaptadas resultaram em velocidades específicas de consumo de sacarose ligeiramente menores [14 mmol GLC eq.(g DW.h. $)^{-1}$ ] do que nos cultivos com células adaptadas.

suc2
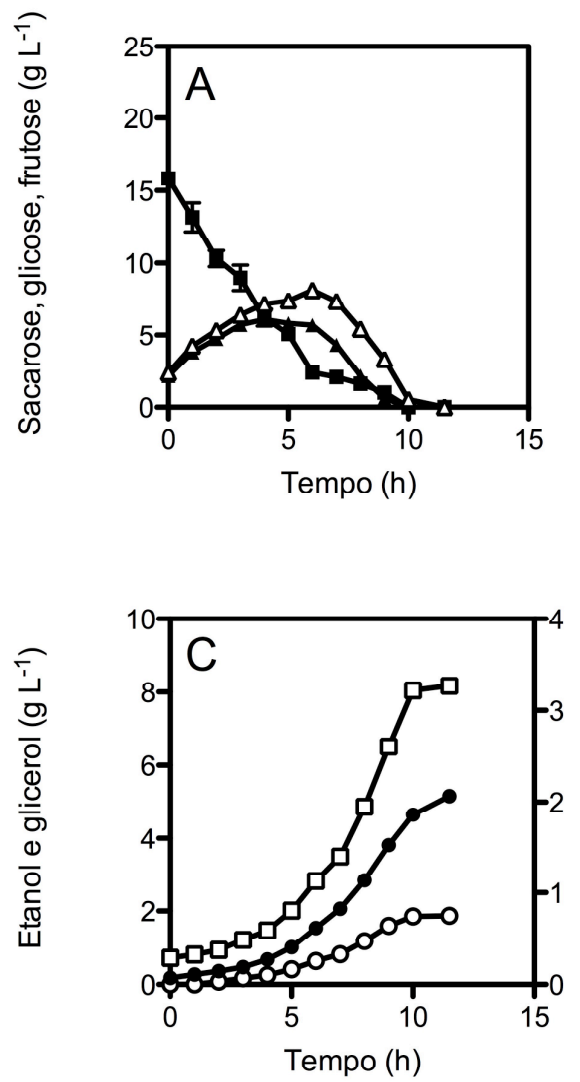

isuc2
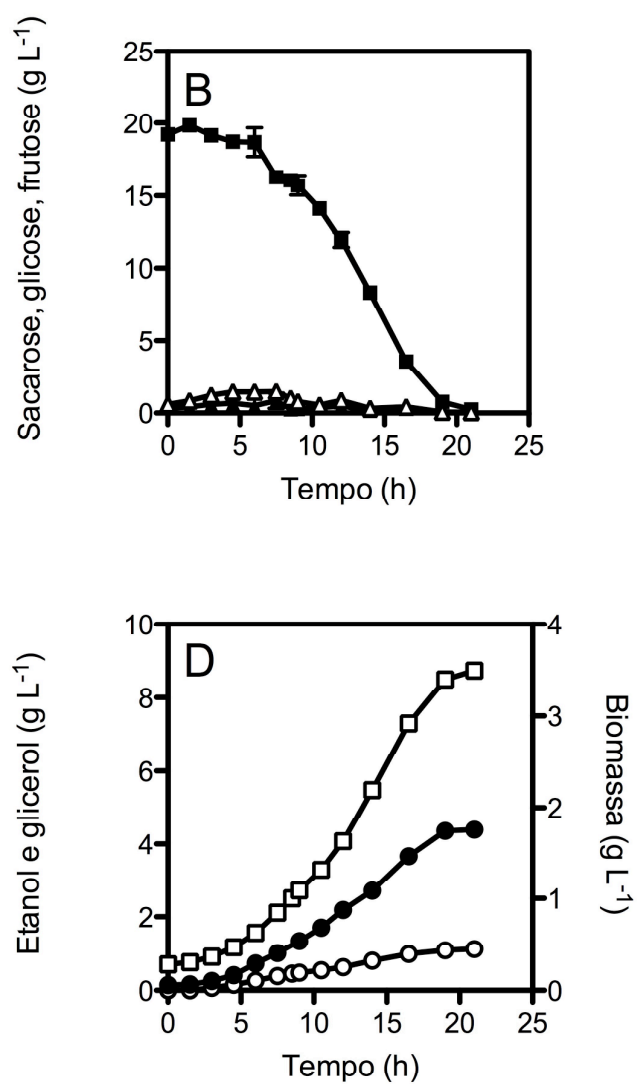

Figura 5.5 - Cultivos descontínuos em anaerobiose plena com as linhagens $\operatorname{SUC2}(A, C)$ e iSUC2 (B,D). Concentração de sacarose $(\boldsymbol{\square})$, glicose $(\boldsymbol{\Delta})$ e frutose $(\triangle),(A, C)$; concentração de etanol $(\square)$, glicerol $(O)$ e biomassa celular $(\bullet)(C, D)$, durante cultivos em meio sintético contendo sacarose a $20 \mathrm{~g} / \mathrm{L}$ iniciais como única fonte de carbono. Os dados apresentados correspondem ao terceiro ciclo de bateladas repetidas e referem-se a média \pm desvio do media de experimentos independentes realizados em duplicata (ver Materiais e Métodos).

Paralelamente a estes dados, observou-se uma menor velocidade específica de produção de etanol $\left(q_{\mathrm{ETH}}\right)$ na linhagem iSUC2 [16,9 $\pm 2,5 \mathrm{mmol}$ ETH.(g DW.h $\left.)^{-1}\right]$ em relação à selvagem $\left.[26,6 \pm 0,2 \mathrm{mmol} \text { ETH.(g DW.h })^{-1}\right]$. As velocidades menores na linhagem iSUC2 podem ser explicadas pelo menor $\mu_{\max }$ desta linhagem $\left(0,17 \pm 0,01 \mathrm{~h}^{-1}\right)$ em comparação à linhagem-referência $\left(0,35 \pm 0 \mathrm{~h}^{-1}\right)$. Apesar das velocidades específicas terem sido menores na linhagem iSUC2, o $Y_{E T H / S}$ (global) foi 7\% maior nesta linhagem em comparação à linhagem SUC2, passando de 0,350 $\pm 0,004$ para 0,374 $\pm 0,014$ g ETH.g GLC eq ${ }^{-1}$. O aumento do $Y_{\text {ETH/S }}$ 
foi acompanhado de um menor fator de conversão de substrato a células, parâmetro que foi de 0,100 $\pm 0,001$ g DW.g GLC eq ${ }^{-1}$ na linhagem-referência e de 0,083 $\pm 0,005$ g DW.g GLC eq ${ }^{-1}$ na linhagem iSUC2, bem como de uma menor produção de glicerol (Figura 5.5).

Muitos trabalhos descritos na literatura têm buscado aumentar o $Y_{\mathrm{ETH} / \mathrm{s}}$ através da diminuição da formação do glicerol, um dos principais subprodutos da fermentação. Uma estratégia é a substituição da especificidade de algumas enzimas-chave pelos seus respectivos co-fatores (normalmente a troca de NADPH por NADH ou vice-versa, dependendo de qual forma da coenzima, reduzida ou oxidada, é usada nas reações). Nissen et al. (2000) verificaram que esta estratégia somente permitiu alcançar um aumento expressivo do $\mathrm{Y}_{\mathrm{ETH} / \mathrm{S}}$ (10\% em relação a linhagem-referência), quando tal estratégia foi combinada a um aumento do custo em ATP para a formação de biomassa (gasto extra incorporado durante a assimilação de amônio). No trabalho de Bro et al. (2006), que igualmente visava a redução da formação de glicerol através da re-oxidação de NADH pela expressão da enzima heteróloga não-fosforilante, NADP ${ }^{+}$-Gliceraldeído 3-Fosfato Desidrogenase (que converte gliceraldeído-3P em glicerato-3P), reporta-se um aumento modesto de $3 \%$ no $Y_{E T H / S}$. Assim, pode-se concluir que estratégias baseadas no aumento do custo energético para a formação de biomassa, como foi o caso do presente estudo, são promissoras para se obter aumentos mais expressivos no $Y_{\mathrm{ETH} / \mathrm{s}}$ em relação à troca de cofatores. Neste texto, o custo energético para a formação de biomassa engloba, além das reações de biossíntese celular, os gastos envolvidos no transporte dos nutrientes.

No presente estudo, a estratégia de se aumentar o rendimento em etanol, pela relocalização do metabolismo de sacarose, parece estar limitada por uma baixa capacidade de transporte da sacarose (passo inicial, essencial para a posterior hidrólise intracelular e metabolização dos monossacarídeos resultantes). De um lado, foi observada uma quantidade elevada de substrato residual nos cultivos em quimiostato (Tabela 5.3). Por outro lado, observou-se uma baixa velocidade específica de crescimento e ausência de etanol nos cultivos descontínuos em frasco agitado. Somando-se a isto, constatou-se um aumento no tempo da fermentação (de 20 para 35 h) na linhagem iSUC2 sem o gene AGT1, em relação a sua isogênica (iSUC2). Com estes resultados, concluímos que era necessário aumentar a afinidade/capacidade do sistema de transporte de sacarose, para que a estratégia de engenharia metabólica empregada, que envolve a relocalização do metabolismo da sacarose, gerasse um melhoramento ainda maior da formação de etanol. 
Deste modo, como continuidade do trabalho, empregou-se a estratégia conhecida como engenharia evolutiva (Sauer, 2001), aplicada à linhagem iSUC2, com o objetivo de se obter um mutante com maior afinidade/capacidade de captação de sacarose e com isto obter linhagens com $\mathrm{Y}_{\mathrm{ETH} / \mathrm{S}}$ ainda maiores. 


\subsection{Engenharia evolutiva para o melhoramento do transporte de sacarose em S. cerevisiae}

\subsubsection{Fisiologia de S. cerevisiae SUC2 e iSUC2 prototróficas em quimiostatos anaeróbios limitados por sacarose}

Relatos científicos recentes apontam diferenças fisiológicas entre linhagens auxotróficas e suas respectivas prototróficas, mesmo quando o meio é suplementado com os respectivos nutrientes auxotróficos, tais como uracila, leucina, metionina, entre outros (Çakar et al., 1999; Pronk, 2002; Corbacho et al., 2010). Assim, antes de serem iniciados os experimentos de evolução com a linhagem que expressa apenas a forma intracelular da invertase (por meio de um promotor forte, $\mathrm{P}_{A D H 1}$ ), decidiu-se verificar se os parâmetros fisiológicos observados com as linhagens auxotróficas para uracila (SUC2 ura- e iSUC2 ura-), durante os experimentos em quimiostato (ver item 5.2), seriam os mesmos obtidos cultivando-se as respectivas linhagens prototróficas (URA3). Para esta finalidade a linhagem prototrófica iSUC2 (MATa URA3 trp1-289 TRP1 $\mathrm{P}_{A D H 1}:$ :iSUC2 MAL2-8 ${ }^{\complement}$ AGT1), foi comparada à linhagem-referência CEN.PK113-7D (MATa URA3 SUC2 MAL2-8 $A G T 1)$, a qual, igualmente à linhagem iSUC2, é prototrófica para a uracila, mas no entanto tem o gene SUC2 selvagem.

As duas linhagens foram cultivadas em quimiostatos limitados por sacarose, sob plena anaerobiose, operados a uma vazão específica $(D)$ de $0,10 \mathrm{~h}^{-1}$. Tais cultivos foram conduzidos empregando-se meio sintético totalmente definido, contendo sacarose como única fonte de carbono e energia. Todos os resultados apresentados e discutidos a seguir referem-se às amostras coletadas durante o estado-estacionário destes cultivos.

Em relação às atividades de invertase nos cultivos com sacarose, foi possível observar que a estratégia de engenharia metabólica resultou na retenção da atividade da invertase no ambiente intracelular na linhagem iSUC2 (Figura 5.6), além de um aumento no valor absoluto da atividade total nesta linhagem, em relação à linhagem SUC2, analogamente ao que havia sido observado anteriormente nos experimentos com as linhagens auxotróficas (ver item 5.2). Por outro lado, na linhagem-referência (SUC2) foram detectadas atividades para as duas formas desta enzima, sendo a forma extracelular responsável pela maior parte da atividade total (91\%). Na linhagem iSUC2, a atividade de invertase foi representada quase que exclusivamente pela forma intracelular (96\%). Ainda assim, foi possível notar, como 
anteriormente na linhagem iSUC2 ura-, que a linhagem iSUC2 também apresentou alguma atividade de invertase extracelular. No entanto, como o método de quantificação de invertase extracelular baseia-se na dosagem de glicose no meio extracelular (ver Materiais e Métodos), não se pode descartar a hipótese de que os produtos de hidrólise da sacarose, mesmo sendo hidrolisada intracelularmente, sejam excretados das células pelos transportadores Hxtp (Boles e Hollemberg, 1997) e detectados no sobrenadante, tratandose assim de uma possível falha da metodologia de dosagem de invertase, conforme discutido anteriormente (ver item 5.2).

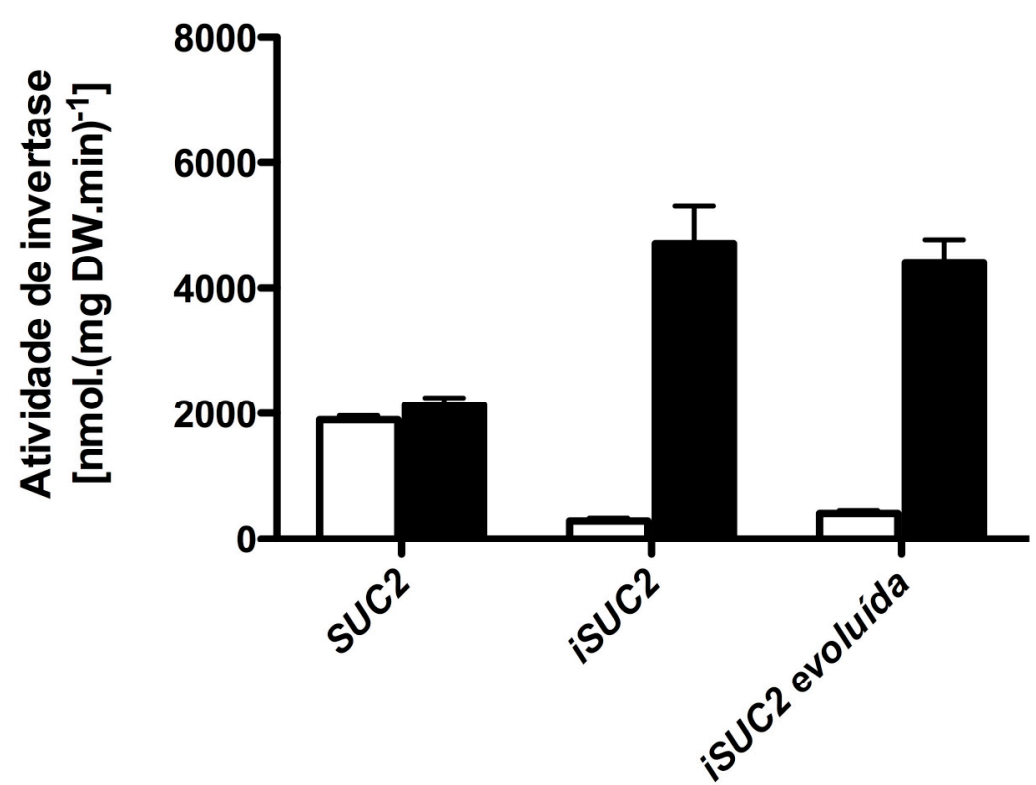

Figura 5.6 - Atividade de invertase nas linhagens SUC2, iSUC2 e iSUC2 evoluída. A atividade de invertase extracelular (barras brancas) foi estimada com células intactas e a atividade total (barras pretas) com células permeabilizadas, ambas coletadas durante o estado-estacionário de quimiostatos limitados por sacarose em anaerobiose. Os valores apresentados são as médias e os desviospadrão de análises realizadas em triplicata, para cada duplicata biológica.

De uma maneira geral, ao se comparar a linhagem iSUC2 com a linhagem-referência (SUC2), nos cultivos limitados por sacarose (Tabela 5.4), foi observado que os parâmetros fisiológicos de interesse foram alterados de forma semelhante aos dados obtidos anteriormente com as linhagens auxotróficas para a uracila (Tabela 5.3). O $\mathrm{Y}_{\mathrm{ETH} / \mathrm{s}}$ foi $4 \%$ maior na linhagem iSUC2 em relação à linhagem SUC2. A $q_{\text {ETH }}$ apresentado pela linhagem iSUC2 foi 5\% superior em relação ao mesmo parâmetro na linhagem SUC2, enquanto o $Y_{x / S}$ foi cerca de 4,5\% menor na linhagem iSUC2 em relação a SUC2. Estes resultados indicam que a estratégia de engenharia metabólica, que teve o intuito de alterar a topologia da hidrólise 
e a energética do transporte da sacarose em $S$. cerevisiae, resultou num aumento do $\mathrm{Y}_{\mathrm{ETH} / \mathrm{S}}$, provavelmente fruto da menor eficiência energética das células que não expressam a invertase extracelular e se vêem obrigadas a transportar a sacarose por transporte ativo. No entanto, de maneira análoga ao observado nos experimentos com as linhagens auxotróficas para a uracila (ver item 5.2), as variações observadas foram menores do que as previstas pelo modelo metabólico (Tabela 5.4). De acordo com o modelo, seria esperada uma diminuição de $25 \%$ no $Y_{X / S}$, ao se comparar a linhagem iSUC2 com a linhagem SUC2. Porém, como pode ser observado, a redução foi de apenas 4,5\%. O mesmo ocorreu com os demais parâmetros $\left(\mathrm{Y}_{\mathrm{ETH} / \mathrm{S}}, q_{\mathrm{ETH}}, q_{\mathrm{CO} 2}, q_{\mathrm{S}}\right.$, etc), todos apresentando variações menores do que as esperadas (Tabela 5.4).

Uma observação importante refere-se às concentrações de sacarose, glicose e frutose residuais (no estado-estacionário), as quais foram muito diferentes entre as linhagens iSUC2 e SUC2. De uma forma geral, a soma dos açúcares residuais foi cerca de 12 vezes superiores na linhagem iSUC2 em comparação à linhagem-referência. Fato interessante é observar que mesmo tendo uma atividade de invertase total superior à da linhagem controle (Figura 5.6), a linhagem iSUC2 não foi capaz de consumir parte da fonte de carbono disponível $[8 \%(p / p)]$. O fato de uma parte substancial da fonte de carbono não ter sido consumida pela linhagem iSUC2 indica uma possível limitação no transporte deste dissacarídeo nesta linhagem. 
Tabela 5.4 - Parâmetros fisiológicos das linhagens SUC2 (CEN.PK113-7D, linhagem-referência), iSUC2 (ausência de invertase extracelular e super-expressão da invertase intracelular; IMI-056), iSUC2 evoluída (linhagem evoluída obtida em quimiostatos anaeróbios longos limitados por sacarose, a partir da linhagem iSUC2; IMM007), iSUC2 evoluída $\Delta$ agt1 (IMM-008), iSUC2 evoluída $\Delta / \Delta$ agt1 (IMM-009), iSUC2 $\mathrm{P}_{\text {TPII }}$ MAL13 (IMI-066) e iSUC2 $\mathrm{P}_{\text {TDH3 }}$ AGT1 (IMI-067) durante o estado estacionário em quimiostatos anaeróbios limitados por sacarose. Os dados estão apresentados como a média \pm o desvio da média de dois experimentos independentes.

\begin{tabular}{|c|c|c|c|c|c|c|c|c|c|}
\hline Parâmetros fisiológicos & SUC2 & iSUC2 & iSUC2 evoluída & $\begin{array}{c}\text { iSUC2 evoluída } \\
\Delta \text { agt1 }\end{array}$ & $\begin{array}{c}\text { iSUC2 evoluída } \\
\Delta / \Delta \text { agt } 1\end{array}$ & $\begin{array}{c}\mathrm{i} S U C 2 \mathrm{P}_{\text {TDHS }} \\
A G T 1\end{array}$ & $\begin{array}{c}\mathrm{iSUC2}_{\text {TPIT }} \\
\text { MAL13 }\end{array}$ & $\underset{(\%)^{(\mathrm{a})}}{i S U C 2 \text { e SUCZ }}$ & $\begin{array}{c}\text { iSUC2 evoluída } \\
\text { e SUC2 } \\
(\%)^{(b)}\end{array}$ \\
\hline Glicose $\left(\mathrm{g} . \mathrm{L}^{-1}\right)$ & $0,05 \pm 0$ & $0,09 \pm 0,04$ & $0,01 \pm 0$ & 0,01 & $0,37 \pm 0,03$ & $0,30 \pm 0,03$ & $0,41 \pm 0,14$ & & \\
\hline Frutose $\left(g . . \mathrm{L}^{-1}\right)$ & $0,11 \pm 0,03$ & $0,16 \pm 0,03$ & $0,03 \pm 0$ & 0,01 & $0,32 \pm 0,03$ & $0,30 \pm 0,03$ & $0,40 \pm 0,13$ & & \\
\hline Sacarose (g GLC eq. $\mathrm{L}^{-1}$ ) & $0,00 \pm 0$ & $1,79 \pm 0,23$ & $0,08 \pm 0$ & 0,09 & $1,51 \pm 0,07$ & $1,05 \pm 0,09$ & $1,6 \pm 0,24$ & & \\
\hline$Y_{x / s}\left(g\right.$ DW.g GLC eq $\left.{ }^{-1}\right)$ & $0,092 \pm 0,001$ & $0,088 \pm 0,001$ & $0,067 \pm 0,001$ & 0,066 & $0,097 \pm 0,001$ & $0,09 \pm 0$ & $0,101 \pm 0,003$ & $-4,5 /(-25)$ & $-27 /(-25)$ \\
\hline$q_{\mathrm{s}}\left[\mathrm{mmol}\right.$ GLC eq. $\left(\mathrm{g}\right.$ DW. $\left.\left.\mathrm{h}^{-1}\right)\right]$ & $6,22 \pm 0,05$ & $6,31 \pm 0,04$ & $8,50 \pm 0,09$ & 8,82 & $5,84 \pm 0,03$ & $6,25+0,08$ & $5,46 \pm 0,31$ & $1,5 /(33)$ & $37 /(33)$ \\
\hline$q \mathrm{CO}_{2}\left[\mathrm{mmol} .\left(\mathrm{g} \mathrm{DW} \cdot \mathrm{h}^{-1}\right)\right]$ & $10,35 \pm 0,04$ & $10,64 \pm 0,22$ & $15,55 \pm 0,18$ & 14,96 & $9,86 \pm 0,57$ & $12,27 \pm 0,04$ & $10,66 \pm 0,13$ & $3 /(40)$ & $50 /(40)$ \\
\hline$q_{\text {ETH }}\left[\mathrm{mmol} .\left(\mathrm{g} \mathrm{DW} \mathrm{h}^{-1}\right)\right]$ & $9,34 \pm 0,18$ & $9,84 \pm 0,02$ & $14,16 \pm 0,41$ & 13,92 & $8,84 \pm 0,03$ & $10,18 \pm 0,14$ & $9,1 \pm 0,06$ & $5 /(43)$ & $52 /(43)$ \\
\hline$Y_{\text {ETH/S }}\left(\right.$ g ETH.g GLC eq $^{-1}$ ) & $0,384 \pm 0,005$ & $0,399 \pm 0,002$ & $0,427 \pm 0,009$ & 0,403 & $0,387 \pm 0,001$ & $0,416 \pm 0,011$ & $0,422 \pm 0,16$ & $4 /(8)$ & $11 /(8)$ \\
\hline$q_{\mathrm{ACE}}\left[\mathrm{mmol} .\left(\mathrm{g} \mathrm{DW} \cdot \mathrm{h}^{-1}\right)\right]$ & $0,01 \pm 0$ & $0 \pm 0$ & $0,03 \pm 0,01$ & 0,03 & $0,02 \pm 0,01$ & $0,01 \pm 0$ & 0 & & \\
\hline$q_{\mathrm{LAC}}\left[\mathrm{mmol} .\left(\mathrm{g} \mathrm{DW} \cdot \mathrm{h}^{-1}\right)\right]$ & $0,08 \pm 0$ & $0,07 \pm 0$ & $0,10 \pm 0$ & 0,10 & $0,07 \pm 0$ & $0,07 \pm 0$ & $0,06 \pm 0,01$ & & \\
\hline$q_{\mathrm{PYR}}\left[\mathrm{mmol} .\left(\mathrm{g} \mathrm{DW} \cdot \mathrm{h}^{-1}\right)\right]$ & $0,01 \pm 0$ & $0,01 \pm 0$ & $0,01 \pm 0$ & 0,01 & $0,01 \pm 0$ & $0,01 \pm 0$ & $0,01 \pm 0$ & & \\
\hline$q_{\text {succ }}\left[\mathrm{mmol} .\left(\mathrm{g} \mathrm{DW} . \mathrm{h}^{-1}\right)\right]$ & $0,03 \pm 0$ & $0,03 \pm 0$ & $0,02 \pm 0$ & 0,02 & $0,02 \pm 0,01$ & $0,03 \pm 0$ & $0,03 \pm 0$ & & \\
\hline$q_{\mathrm{GLYC}}\left[\mathrm{mmol} .\left(\mathrm{g} \mathrm{DW} \cdot \mathrm{h}^{-1}\right)\right]$ & $0,77 \pm 0,01$ & $0,69 \pm 0$ & $0,85 \pm 0,03$ & 0,90 & $0,70 \pm 0,01$ & $0,68+0,01$ & $0,66 \pm 0,01$ & $-10 /(0)$ & $10 /(0)$ \\
\hline Balanço de carbono $(\%)^{(c)}$ & $96,2 \pm 0,2$ & $97,4 \pm 0,8$ & $100,1 \pm 0,8$ & 95 & $97,4 \pm 1,4$ & $103,7+1,7$ & $106,2 \pm 4,4$ & & \\
\hline
\end{tabular}

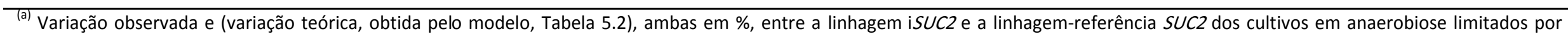
sacarose.

(b) Variação observada e (variação teórica, obtida pelo modelo, Tabela 5.2), ambas em \%, entre a linhagem iSUC2 evoluída e a linhagem-referência SUC2 dos cultivos em anaerobiose limitados por sacarose.

(c) Balanço de carbono foi estimado usando-se uma composição de biomassa de 25,1 g/C-mol para cultivos anaeróbios (Verduyn et al., 1990) e um conteúdo de cinzas de 7\% (Nielsen et al., 2003). 
Até esta etapa do trabalho, a análise do transporte de sacarose havia sido realizada empregando-se sacarose marcada $\operatorname{com}^{14} \mathrm{C}\left({ }^{14} \mathrm{C}\right.$-sacarose), o que é pratica comum no estudo da cinética do transporte de dissacarídeos. No entanto, alguns estudos (Serrano, 1977; Benito e Lagunas, 1992; Stambuk e Araújo, 2001) apontam que, quando altas concentrações de substrato marcado são utilizadas para tais medidas, existe o risco de ocorrerem ligações não-específicas desses substratos às células de levedura (ou até mesmo aos filtros empregados), levando a erros nestas medidas (gerando superestimativas). Adicionalmente, outro problema encontrado com o uso de substratos radioativos é o fato de que quando os mesmos são metabolizados pelas células, ocorre liberação de ${ }^{14} \mathrm{CO}_{2}$ que igualmente leva a erros nas medidas (gerando subestimativas). Um outro fator agravante, específico para o caso da sacarose radioativa, é que esta pode ser hidrolisada extracelularmente durante o período de incubação, e os monossacarídeos radioativos liberados $\left({ }^{14} \mathrm{C}\right.$-glicose e ${ }^{14} \mathrm{C}$-frutose $)$ podem ser assimilados pelas células (por difusão facilitada), contribuindo assim para uma falsa medida de transporte. Em vista do exposto, decidiu-se utilizar, a partir deste ponto do trabalho, outra técnica para estimar o transporte. Esta técnica é conhecida como medida do transporte de dissacarídeos pelo co-transporte com íons $\mathrm{H}^{+}$ou simplesmente co-transporte de sacarose $/ \mathrm{H}^{+}$(Stambuk et al., 1999; Stambuk e Araújo, 2001). Nesta determinação, faz-se uso da medida da alcalinização do meio de cultura, que ocorre após exposição das células à presença do dissacarídeo. Esta alcalinização é resultante do co-transporte do dissacarídeo com íons $\mathrm{H}^{+}$, que apresenta uma estequiometria de $\mathrm{um}^{+}$co-transportado por molécula de sacarose (ou outro dissacarídeo) assimilada pelas células (Serrano, 1977; Stambuk et al., 1999; ver Matérias e Métodos).

Os dados de co-transporte de sacarose $/ \mathrm{H}^{+}$, utilizando sacarose a $70 \mathrm{mM}$, são apresentados na Figura 5.7. Primeiramente, é preciso ressaltar que, como a concentração de sacarose utilizada nesta medida é cerca de 10 vezes superior aos valores de $k_{\mathrm{m}}$ já reportados para o co-transporte de sacarose $/ \mathrm{H}^{+}$em S. cerevisiae (Stambuk et al., 2000; Badotti et al., 2008), os dados podem ser interpretados como sendo referentes à capacidade máxima de transporte $\left(V_{\max }\right)$ deste dissacarídeo. Durante o estado estacionário, a linhagem iSUC2 apresentou transporte de sacarose maior do que a linhagem SUC2. Na literatura, não foi possível encontrar valores de transporte de sacarose durante o estado estacionário em cultivos anaeróbicos limitados por sacarose. 
O transporte de sacarose ( $\left.V_{\text {transporte }}\right)$ medido com a linhagem iSUC2 foi em torno de 1,5 mmol SUC.(g DW.h) ${ }^{-1}$ [25 nmol SUC.(mg DW.min) ${ }^{-1}$ ] (Figura 5.4.2), enquanto a $q_{\text {suc }}$ foi de 3,15 mmol SUC.(g DW.h $)^{-1}$ [6,3 mmol de GLC eq.(g DW.h $\left.)^{-1}\right]$ (Tabela 5.4), ou seja, maior que o transporte. Numa linhagem que depende do transporte para metabolizar a sacarose, era esperado que o $V_{\text {transporte }}$ fosse igual ou superior à $q_{\text {suc }}$. Assim, é possível especular que parte da sacarose foi utilizada de uma maneira diferente da esperada, ou seja, através do transporte e subseqüente hidrólise intracelular. Ou seja, parte da sacarose pode ter sido hidrolisada extracelularmente e os monossacarídeos captados por difusão facilitada. Isto, em parte, explicaria o fato de que os parâmetros fisiológicos observados na linhagem iSUC2 ( $\mathrm{Y} x / \mathrm{s}$ e $\mathrm{Y}_{\mathrm{ETH} / \mathrm{S}}$ ) foram diferentes dos previstos pelo modelo metabólico (Tabela 5.4).

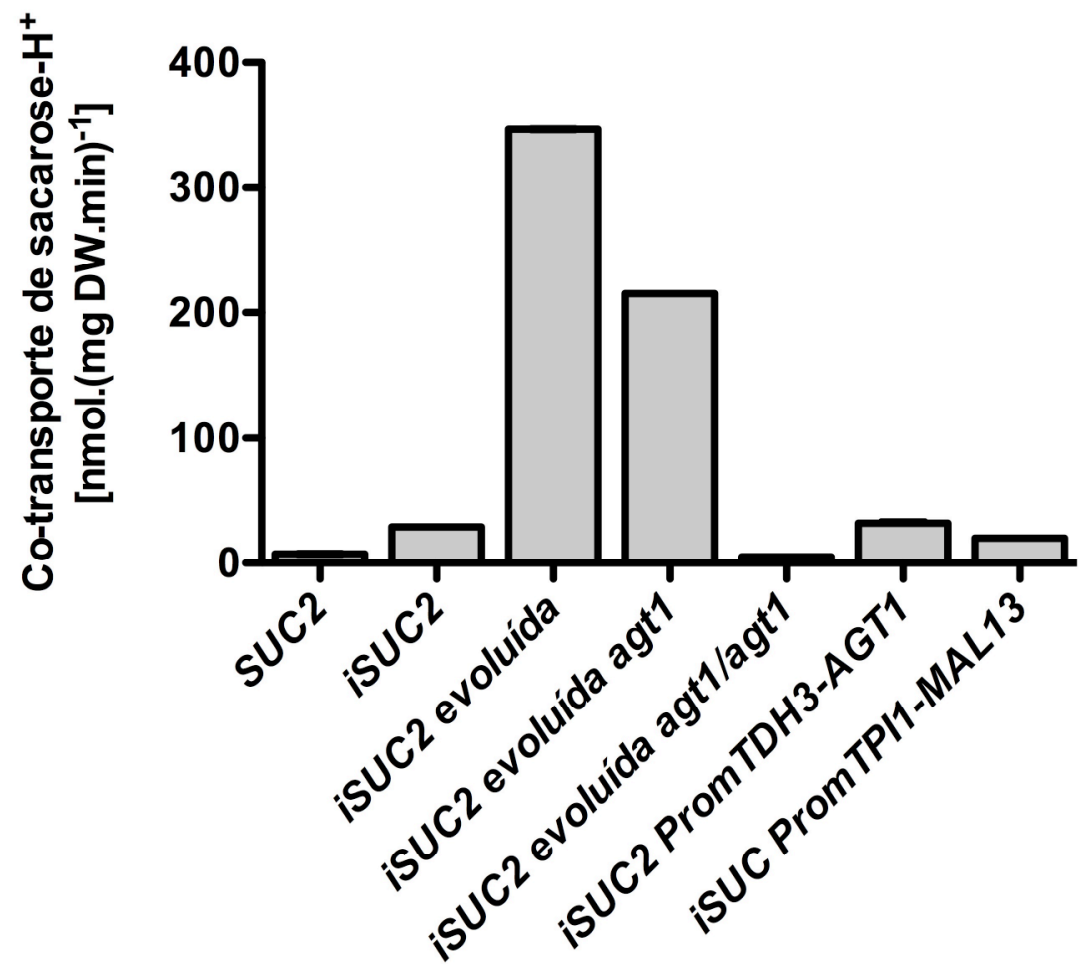

Figura 5.7 - Atividade de co-transporte de sacarose com $\mathrm{H}^{+}$nas linhagens SUC2, iSUC2, iSUC2 evoluída, iSUC2 evoluída $\triangle$ agt1, iSUC2 evoluída $\Delta / \Delta$ agt1, iSUC2 $\mathrm{P}_{T D H 5} A G T 1$, iSUC2 $\mathrm{P}_{T P I 1}-M A L 13$. A atividade de transporte foi determinada em células coletadas durante o estado-estacionário de quimiostatos limitados por sacarose em anaerobiose, conforme descrito na parte de Materiais e Métodos. Os valores apresentados são as médias e os desvios-padrão de análises realizadas em triplicata, para cada duplicata biológica.

Uma possibilidade para explicar a incoerência entre os dados de $Y_{x / s}$ observado e teórico (previsto pelo modelo) é que o conteúdo intracelular de carboidratos de reserva da linhagem iSUC2 seja diferente daquele da linhagem SUC2, conforme previamente reportado 
por Wisselink et al., (2009). No entanto, os valores de trealose e glicogênio na biomassa foram muito próximos entre as duas linhagens (Figura 5.8), descartando parcialmente esta hipótese.

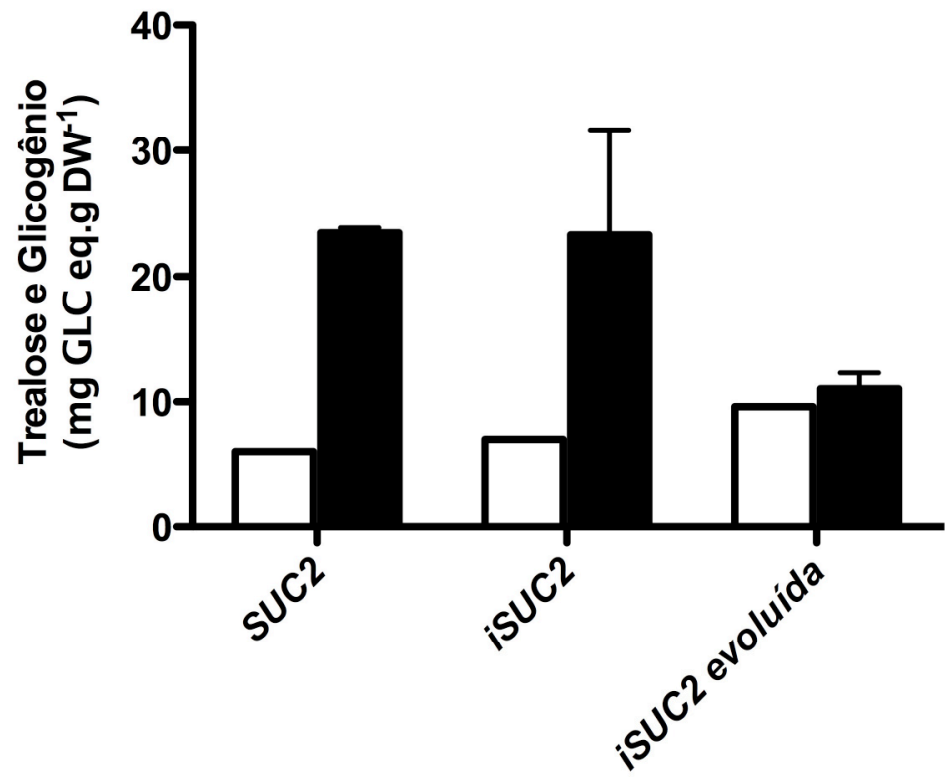

Figura 5.8 - Conteúdo de carboidratos de reserva em células de levedura, coletadas durante o estado estacionário de quimiostatos anaeróbios limitados por sacarose. Teores de trealose (barras brancas) e glicogênio (barras pretas) nas linhagens SUC2, iSUC2, iSUC2 evoluída. Os valores apresentados são as médias e os desvios-padrão de análises realizadas em triplicata, para cada duplicata biológica.

De uma maneira geral, os resultados obtidos com as linhagens prototróficas durante os quimiostatos anaeróbicos limitados por sacarose foram semelhantes aos resultados obtidos com as linhagens auxotróficas para a uracila (SUC2 ura- e iSUC2 ura-). As diferenças observadas em alguns parâmetros fisiológicos $\left(q_{\mathrm{ETH}}, \mathrm{Y}_{\mathrm{X} / \mathrm{s}}, q_{\mathrm{CO} 2}\right.$, etc) entre as linhagens auxotróficas e suas correspondentes prototróficas podem ser atribuídas aos diferentes equipamentos e métodos de quantificação empregados nos dois laboratórios onde foram realizados os estudos (LEB/USP e LMI/TU Delft). Pelos dados apresentados até este ponto do trabalho, tanto obtidos com as linhagens auxotróficas, como com as linhagens prototróficas, observa-se que a estratégia de engenharia metabólica empregada por Stambuk, et al. (2009), que modificou a topologia e a energética do metabolismo de sacarose em S. cerevisiae, apesar das limitações encontradas (parâmetros fisiológicos diferentes dos esperados e concentrações de açúcares residuais elevadas), pode ser considerada promissora, no sentido de aumentar a conversão de sacarose em etanol $\left(\mathrm{Y}_{\mathrm{ETH} / \mathrm{S}}\right)$. Vale 
destacar que a relocalização do metabolismo de sacarose, de extracelular para intracelular, teria ainda a seguinte vantagem no ambiente industrial: a diminuição da competição pela fonte de carbono com microrganismos contaminantes do processo, que freqüentemente não metabolizam dissacarídeos tão bem quanto monossacarídeos.

\subsubsection{Engenharia evolutiva aplicada à linhagem isUC2}

Em vista dos dados obtidos, buscou-se melhorar ainda mais o fenótipo da linhagem iSUC2, no sentido de aumentar a afinidade/capacidade do co-transporte de sacarose $/ \mathrm{H}^{+}$ nesta linhagem, como forma de se aumentar ainda mais o $Y_{E T H / S}$, com a concomitante diminuição do $Y_{x / s}$, procurando-se chegar mais próximo aos valores calculados pelo modelo metabólico (Tabela 5.2). Para alcançar tal objetivo, estratégias de engenharia evolutiva, que se baseiam no princípio da variação e seleção natural (Sauer, 2001), foram empregadas. Devido ao fato de existir, em cultivos contínuos do tipo quimiostato, uma forte pressão seletiva no sentido de selecionar células com maior afinidade/capacidade de transporte pelo substrato limitante, que se encontra em baixas concentrações dentro do reator (Wick et al., 2002; Jansen et al., 2004), é esperado que durante cultivos longos limitados por sacarose, seja possível a seleção de mutantes com maior afinidade/capacidade para o co-transporte de sacarose $/ \mathrm{H}^{+}$. O surgimento de um mutante deste tipo dentro do reator causa uma diminuição na concentração residual de sacarose, o que diminui a velocidade específica de crescimento com que as células originais são capazes de crescer nesta nova condição (isto pode facilmente ser explicado pelo modelo de Monod para o crescimento microbiano). Sendo assim, as células originais tendem a ser lavadas do sistema e uma nova população derivada do mutante com maior afinidade/capacidade por sacarose tenderá a dominar o reator, já que, ao contrário das células originais, esta nova população consegue crescer com velocidade específica $(\mu)$ igual à vazão específica do quimiostato $(D)$ na nova concentração residual do substrato limitante.

Desta maneira, a linhagem iSUC2 foi submetida a um cultivo contínuo sob limitação de sacarose ao longo de várias gerações. Uma forma de se avaliar a eficiência desta estratégia de melhoramento do co-transporte de sacarose $/ \mathrm{H}^{+}$é acompanhar a concentração do substrato limitante ao longo do cultivo (Brown et al., 1998; Ferea et al., 1999). Além 
disto, acompanhou-se também a capacidade do transporte de sacarose ao longo do cultivo. Para tanto, o transporte de sacarose foi medido indiretamente pelo co-transporte de $\mathrm{H}^{+}$, que se baseia na estequiometria de $1: 1$ no co-transporte de sacarose: $\mathrm{H}^{+}$em células de $S$. cerevisiae (Stambuk et al., 2000). Durante este cultivo prolongado, a concentração residual de sacarose passou de cerca de $2 \mathrm{~g} \cdot \mathrm{L}^{-1}$ para menos de $0,1 \mathrm{~g} \cdot \mathrm{L}^{-1}$ após cerca de 50-60 gerações (Figura 5.9). Paralelamente, a capacidade do co-transporte de sacarose $/ \mathrm{H}^{+}$, que indica de maneira indireta a capacidade de transportar sacarose, aumentou de 10 para cerca de 200 nmol.(mg DW.min) ${ }^{-1}$, perfazendo um aumento de 20 vezes.

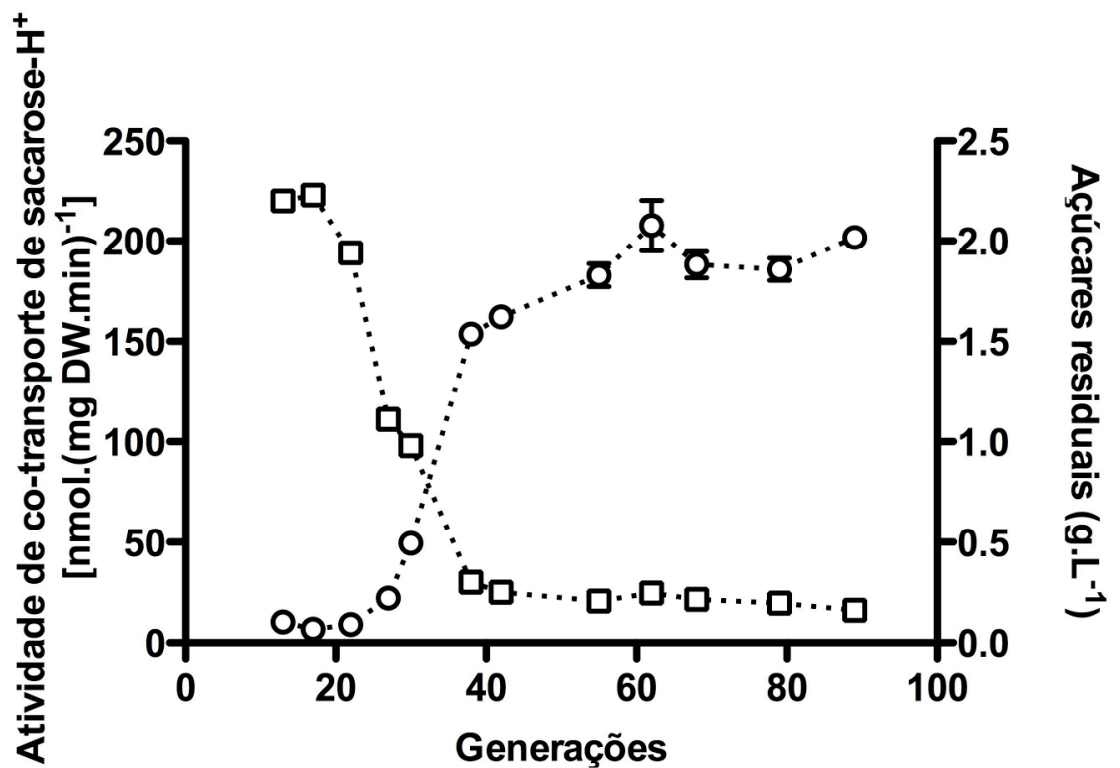

Figura 5.9 - Experimento de evolução com a linhagem iSUC2. Concentração dos açúcares residuais (sacarose) $(\square)$ e a atividade do co-transporte de sacarose- $\mathrm{H}^{+}(\mathrm{O})$ ao longo de cultivo contínuo limitado por sacarose em regime de anaerobiose. $O$ experimento foi conduzido em duplicata, e no gráfico são representados apenas os dados de um dos cultivos, na forma da média e desvio-padrão das medidas feitas em triplicata de uma mesma amostra.

Após cerca de 90 gerações, em que tanto a concentração de açúcar residual como a atividade de co-transporte de sacarose- $\mathrm{H}^{+}$permaneceram praticamente constantes por mais de 30 gerações, uma amostra foi coletada e espalhada na superfície de uma placa de Petri contendo meio YPD solidificado, de forma a se isolar colônias e armazená-las conforme o protocolo utilizado para o estoque das linhagens (ver item 4.2, em Materiais e Métodos). Uma destas colônias, designada iSUC2 evoluída (IMM-007), foi caracterizada em quimiostato limitado por sacarose em anaerobiose. Enquanto as atividades de invertase total e extracelular desta linhagem evoluída não foram alteradas em relação aos mesmos 
parâmetros na linhagem iSUC2 (Figura 5.6), a atividade de co-transporte de sacarose $/ \mathrm{H}^{+}$ aumentou consideravelmente na linhagem evoluída, passando de 25 para cerca 346 nmol.(mg DW.min) ${ }^{-1}$ (Figura 5.7). A diferença observada nos valores do transporte de sacarose $/ \mathrm{H}^{+}$entre os instantes finais do experimento de evolução (Figura 5.9) e o cultivo com a linhagem iSUC2 evoluída é um forte indicativo de que havia distintos fenótipos "evoluídos" no reator ao longo do experimento de evolução. Este fenômeno já foi observado diversas vezes em experimentos semelhantes, sob outras limitações nutricionais (Brown et al., 1998; Gresham et al., 2008, 2011). No entanto, o fato de os parâmetros fisiológicos da linhagem iSUC2 evoluída serem diferentes daqueles da linhagem iSUC2, quando ambas são comparadas durante quimiostatos limitados por sacarose em anaerobiose, é um forte indicativo de que realmente ocorreram mutações na linhagem iSUC2 evoluída, em relação à linhagem iSUC2 e não simplesmente uma adaptação.

Ao se comparar os parâmetros fisiológicos da linhagem iSUC2 evoluída com a linhagem referência (SUC2) nos cultivos limitados por sacarose, foi observado que os parâmetros relevantes para o objetivo deste estudo $\left(\mathrm{Y}_{\mathrm{ETH} / \mathrm{S}}, q_{\mathrm{ETH}}\right.$, e $\left.\mathrm{Y}_{\mathrm{X} / \mathrm{S}}\right)$, foram alterados em magnitudes semelhantes às variações estimadas pelo modelo metabólico (Tabela 5.2). 0 $\mathrm{Y}_{\mathrm{ETH} / \mathrm{S}}$ foi $11 \%$ maior na linhagem iSUC2 evoluída em relação à linhagem SUC2, enquanto a $q_{\mathrm{ETH}}$ observada na linhagem evoluída foi 52 \% superior a $q_{\mathrm{ETH}}$ da linhagem-referência (SUC2), sendo que o modelo previa uma variação de 8 e $43 \%$ nos parâmetros $Y_{\mathrm{ETH} / \mathrm{s}}$ e $q_{\mathrm{ETH}}$, respectivamente. Adicionalmente, o $\mathrm{Y}_{\mathrm{x} / \mathrm{s}}$ foi $27 \%$ menor na linhagem evoluída em relação a SUC2, sendo a variação esperada de $25 \%$. A concentração residual de sacarose foi muito menor na linhagem evoluída em relação à iSUC2, indicando um aumento expressivo na afinidade/capacidade do transporte de sacarose na linhagem evoluída, uma vez que a concentração do substrato residual no quimiostato está diretamente ligada à afinidade/capacidade do transporte para o substrato limitante (Jansen et al., 2004).

À primeira vista, o aumento da capacidade/afinidade do transporte de sacarose obtido após a evolução da linhagem iSUC2 parece ser o fator responsável pela mudança nos parâmetros fisiológicos, aumentando a capacidade de formação de etanol pelas células, com a concomitante diminuição da conversão de sacarose em biomassa. Como continuação do trabalho, buscou-se identificar alterações genéticas que pudessem explicar o novo fenótipo obtido ao longo da evolução em quimiostato. Para tanto, o transcriptoma e a seqüência de determinados genes da linhagem melhorada foram investigados e comparados aos dados 
correspondentes na linhagem original, procurando-se identificar possíveis mutações e/ou genes que tiveram sua expressão alterada, durante o processo de evolução.

\subsubsection{Análise do transportador Agt1p na linhagem iSUC2 evoluída}

Com o intuito de investigar o envolvimento do gene $A G T 1$, que codifica a proteína transportadora Agt1p ( " $\alpha$-g/ucoside transporter"), na utilização de sacarose pela linhagem evoluída, mutantes deletados no referido gene foram construídos.

Através do emprego de técnicas de PCR diagnóstico (Materiais e métodos, item 4.11.4) sobre o DNA genômico das linhagens SUC2 e iSUC2 e seus respectivos mutantes $\Delta$ agt1, foi possível verificar que as linhagens $S U C 2$ e iSUC2 apresentam apenas uma cópia do gene $A G T 1$ em seus genomas (Figura $5.10 \mathrm{~A}$ e $\mathrm{B}$ ).

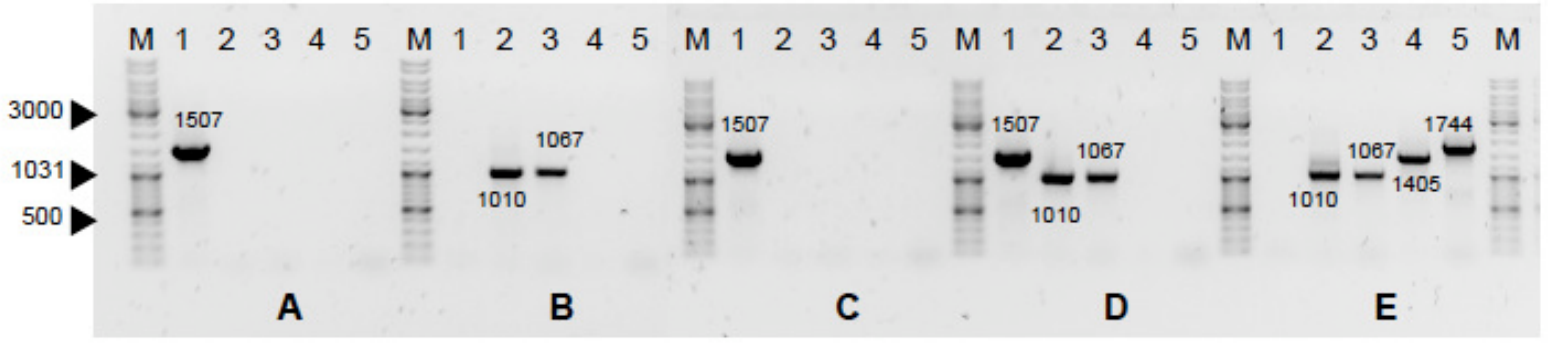

Figura 5.10 - Verificação da presença, bem como confirmação da deleção do gene $A G T 1$ nas linhagens iSUC2 (A), iSUC2 $\triangle$ agt1 (B), iSUC2 evoluída (C), iSUC2 evoluída $\triangle a g t 1$ (D) e iSUC2 evoluída $\Delta / \Delta a g t 1$ (E). Conforme descrito, os DNAs genômicos das linhagens foram extraídos e analisados, através de $\mathrm{PCR}$, para a verificação da presença do gene $A G T 1$, com os primers 1687/1688 (internos ao gene AGT1), com produto de amplificação de 1507 pb (linha 1); para a confirmação da deleção com o cassete $A G T 1-K O-K a n M X$, com os primers $1472 / 9$ e 1473/10, o quais produziriam os fragmentos de 1010 e 1067 pb, respectivamente, caso a inserção do cassete ocorresse no sítio correto (linhas 2 e 3); e para a confirmação da deleção com o cassete AGT1-KO-hphN, com os primers 1007/1472 e 1008/1473, os quais produziriam os fragmentos de 1405 e 1744 pb, respectivamente, caso a inserção do cassete ocorresse no sítio correto (linhas 4 e 5); Marcador molecular (linha $M$, GeneRuler Ladder DNA Mix, Fermentas). Os produtos de PCR estão mostrados em gel de agarose $1 \%$. Os números ao lado do gel indicam o tamanho dos marcadores e os números sobre o gel o tamanho dos produtos amplificados (em pb).

Após a deleção do gene $A G T 1$ na linhagem iSUC2 evoluída, verificou-se por meio de PCR diagnóstico a presença de ao menos uma segunda cópia deste gene na linhagem resultante (iSUC2 evoluída $\Delta$ agt1) (Figura 5.10 D). Como se pode notar na Figura $5.10 \mathrm{D}$, foi observada nesta linhagem a presença dos produtos de amplificação de 1010 e 1067 pb, os quais confirmam a inserção do cassete $A G T 1-K O-K a n M X$ na posição correta, confirmando a 
deleção de uma cópia do gene $A G T 1$. Porém, foi observado o fragmento de 1507 pb, que indica a presença de uma cópia extra do gene AGT1 nesta linhagem. Apenas quando esta segunda cópia foi deletada, criando a linhagem iSUC2 evoluída $\Delta / \Delta a g t 1$, constatou-se que não havia mais nenhuma cópia do gene, concluindo-se assim que durante a evolução ocorreu uma duplicação do gene $A G T 1$.

Metodologia semelhante à descrita acima foi aplicada à linhagem iSUC2 evoluída, verificando-se que o gene $M A L 13$ também foi duplicado durante a evolução (item 4.11.6; dados não apresentados).

Duplicações gênicas vêm sendo relatadas durante experimentos de evolução cuja pressão seletiva é a limitação nutricional. Brown et al. (1998) mostraram que o cultivo em regime de quimiostato limitado por glicose por cerca de 450 gerações com S. cerevisiae resultou numa linhagem evoluída apresentando maior afinidade pelo substrato limitante, do que a linhagem original. Foi verificado que a razão para este novo fenótipo foi a ocorrência de múltiplas duplicações nos transportadores de alta afinidade para glicose (Hxt6p e Hxt7p), as quais teriam ocorrido em decorrência de "crossing-overs" desemparelhados entre os genes HXT6 e HXT7 (que encontram-se dispostos de forma seqüencial no cromossomo IV), durante a troca das cromátides irmãs. Em cultivos contínuos limitados por glicose ou sulfato, Gresham et al. (2008) observaram amplificações no número de cópias de genes relativos aos respectivos sistemas de transporte para estes nutrientes.

Para avaliar o papel do gene $A G T 1$ na utilização de sacarose pela linhagem evoluída, os parâmetros fisiológicos de dois mutantes deletados no referido gene (linhagens iSUC2 evoluída $\Delta$ agt1 e iSUC2 evoluída $\Delta / \Delta a g t 1)$ foram obtidos em quimiostatos anaeróbios limitados por sacarose. A deleção de apenas uma das cópias do gene AGT1 praticamente não alterou a maior parte dos parâmetros avaliados, quando comparados aos parâmetros correspondentes da linhagem contendo as duas cópias do gene AGT1 (iSUC2 evoluída). As únicas diferenças observadas foram no co-transporte de sacarose/ $\mathrm{H}^{+}$, que passou de 346 para 215 nmol.(mg DW.min) ${ }^{-1}$ com deleção de uma das cópias do gene (Figura 5.7), e o $\mathrm{Y}_{\mathrm{ETH} / \mathrm{S}}$, que decaiu cerca de $5 \%$ na linhagem $\Delta$ agt1 em relação à linhagem iSUC2 evoluída (Tabela 5.4). No entanto, como o cultivo em quimiostato com a linhagem iSUC2 evoluída $\Delta$ agt1 não foi realizado em duplicata, a diminuição no $Y_{E T H / s}$ deve ser interpretada com cautela. 
Por outro lado, o mutante deletado nas duas cópias do gene AGT1 (iSUC2 evoluído $\Delta / \Delta$ agt1) apresentou diferenças marcantes em relação à linhagem iSUC2 evoluída, bem como em relação à linhagem nocauteada em apenas uma das cópias (iSUC2 evoluída $\triangle a g t 1$ ). $\mathrm{O}$ transporte ativo de sacarose por co-transporte com $\mathrm{H}^{+}$foi praticamente abolido $[<5$ nmol.(mg DW.min $)^{-1}$ ] (Figura 5.7). Como conseqüência, as concentrações de glicose, frutose e sacarose residuais, durante o cultivo com esta linhagem, foram elevadas $(0,37 ; 0,32 ; 1,51 \mathrm{~g}$ GLC eq. $L^{-1}$, respectivamente), em relação aos cultivos realizados com a linhagem iSUC2 evoluída $\left(0,01 ; 0,03 ; 0,08 \mathrm{~g}\right.$ GLC eq. $\mathrm{L}^{-1}$, respectivamente). De um modo geral, a linhagem iSUC2 evoluída $\Delta / \Delta a g t 1$ parece ter perdido o desempenho fermentativo favorável que havia sido adquirido após a evolução, apresentando valores de $\mathrm{Y}_{\mathrm{X} / \mathrm{S}}, \mathrm{Y}_{\mathrm{ETH} / \mathrm{S}}, q_{\mathrm{ETH}}$, próximos à da linhagem-referência (SUC2), e a concentração dos açucares residuais semelhantes a da linhagem iSUC2 (Tabela 5.4). Todas estas observações indicam que o gene $A G T 1$ tem um papel determinante no metabolismo da sacarose pela linhagem iSUC2 evoluída. Adicionalmente, os resultados apresentados sugerem que a regulação do gene $A G T 1$ na linhagem iSUC2 evoluída possa ser diferente daquela existente na linhagem iSUC2 original, uma vez que a linhagem evoluída com apenas uma das cópias do gene (iSUC2 evoluída $\triangle$ agt1) apresentou desempenho consideravelmente diferente da linhagem iSUC2 original (Tabela 5.4), que igualmente apresenta apenas uma cópia do gene AGT1. Estes resultados enfatizam a importância do gene $A G T 1$ no transporte ativo da sacarose, e são um forte indicativo de que a duplicação do gene $A G T 1$ pode ser a única mutação (ou pelo menos a mais importante) causadora do novo fenótipo, obtido ao longo da evolução.

Para averiguar esta hipótese, ou seja, para verificar se a adição de uma segunda cópia do gene $A G T 1$ (sob controle de um promotor forte) seria suficiente para provocar o fenótipo evoluído na linhagem iSUC2, uma segunda cópia do gene $A G T 1$, sob controle do promotor forte $\mathrm{P}_{T D H 3}$, foi inserida no lócus ura3-52 da linhagem iSUC2 ura-. A linhagem resultante, iSUC2 $\mathrm{P}_{T D H 3} A G T 1$ foi cultivada em quimiostato anaeróbico limitado por sacarose (Tabela 5.4). Como pode ser observado na Figura 5.7, a adição de uma cópia do gene AGT1, sob controle do promotor forte $\mathrm{P}_{T D H 3}$, não resultou em aumento da capacidade de co-transporte de sacarose $/ \mathrm{H}^{+}$, em comparação à linhagem iSUC2. No entanto, aumentou em 18 e $9 \%$ os parâmetros $q_{\mathrm{CO} 2}$ e $q_{\mathrm{ETH}}$, respectivamente, em comparação à linhagem-referência (SUC2). Adicionalmente, houve uma diminuição de $2 \%$ no $Y_{X / S}$ e um aumento de $8 \%$ no $Y_{E T H / s}$ quando a linhagem iSUC2 $\mathrm{P}_{T D H^{3}}$ AGT1 foi comparada à linhagem-referência (SUC2). Assim, os 
aumentos e diminuições encontrados, foram todos menores do que os observados na linhagem iSUC2 evoluída (Tabela 5.4), mas parecem indicar que a duplicação do gene AGT1 durante a evolução, somada a uma regulação diferenciada do mesmo (no caso, a expressão por meio de um promotor forte) foram eventos importantes na aquisição no fenótipo evoluído. Vale destacar que a linhagem iSUC2, que possui o gene AGT1 selvagem, apresentou aumentos de apenas 3,5 e $4 \%$ nos parâmetros $q_{\mathrm{CO} 2}$, $q_{\text {ETH }}$ e $Y_{\mathrm{ETH} / \mathrm{S}}$ respectivamente, em comparação à linhagem-referência (SUC2). No entanto, como na linhagem iSUC2, os níveis dos açúcares residuais foram elevados ( 1,6 g GLC eq. $\left.\mathrm{L}^{-1}\right)$ nos cultivos com a linhagem iSUC2 $\mathrm{P}_{T D H 3}-A G T 1$, o que é um indicativo de limitação no transporte de sacarose (Tabela 5.4).

Como forma alternativa para aumentar a atividade do transporte de sacarose na linhagem iSUC2, buscando-se simular a evolução obtida em quimiostato, o promotor forte $\mathrm{P}_{T P I 1}$ foi inserido a montante do gene MAL13. Este gene, que teve expressão aumentada na linhagem iSUC2 evoluída, em relação à iSUC2, de acordo com os resultados da análise transcriptômica (Tabela 5.5) e foi duplicado na linhagem iSUC2 evoluída (dados não apresentados), codifica uma proteína de regulação positiva, que aumenta a expressão do gene AGT1 (Needleman 1991). O comportamento dos parâmetros fisiológicos da linhagem resultante, iSUC2 $\mathrm{P}_{T P I I}-M A L 13$, quando cultivada em quimiostato anaeróbico limitado por sacarose, é de difícil interpretação. Alguns parâmetros, para os quais se esperava um aumento na linhagem iSUC2 $\mathrm{P}_{T P I I}-M A L 13$, em relação à linhagem-referência (SUC2), diminuíram. Por exemplo, observou-se uma diminuição da $q_{\mathrm{ETH}}$ e da $q_{\mathrm{s}}$ (de 3 e $12 \%$, respectivamente) (Tabela 5.4). Para o $\mathrm{Y}_{\mathrm{X} / \mathrm{S}}$, ao invés de uma diminuição, observou-se um aumento do mesmo (10\%). A medida de co-transporte de $\mathrm{H}^{+}$com esta linhagem foi baixa (Figura 5.7) e a concentração de açucares residuais elevada ( 2,4 g GLC eq. $\mathrm{L}^{-1}$ ). Surpreendemente, o $\mathrm{Y}_{\mathrm{ETH} / \mathrm{S}}$ aumentou cerca de $10 \%$ em relação à linhagem-referência (SUC2). Por todas estas evidências e, mesmo sem saber a causa deste fenótipo, o que se conclui é que esta estratégia de modificação genética não resultou numa linhagem com fenótipo próximo ao fenótipo da linhagem iSUC2 evoluída.

Cabe ressaltar que a presença do promotor nas linhagens modificadas foi apenas verificada por meio de PCR diagnóstico (Materiais e Métodos). Assim, os níveis de expressão dos dois genes ( $A G T 1$ e MAL13) não foram avaliados. Portanto, não é possível concluir se os 
fenótipos observados devem-se a uma falha na super-expressão dos referidos genes, ou se, mesmo quando super-expressos, tais genes não são capazes de conferir o fenótipo evoluído.

Para verificar se o fenótipo evoluído poderia ter sido resultado de mutações no gene $A G T 1$, ou em sua região promotora, estas regiões foram seqüenciadas nas linhagens iSUC2, iSUC2 evoluída, e iSUC2 evoluída $\triangle$ agt1 (item 4.13). A seqüência de nucleotídeos do gene AGT1 da linhagem iSUC2 evoluída foi comparada à seqüência correspondente na linhagem iSUC2 original. Vale destacar que, a montante do gene AGT1 e a jusante do gene MAL12 encontra-se uma região inter-gênica (Han et al., 1995), na qual está localizada a seqüência denominada UAS MAL (que compreende os nucleotídeos -413 até o -494 da região promotora do gene $A G T 1)$. Esta seqüência é o sítio de ligação da proteína de regulação positiva Malx3p, que controla a transcrição do gene AGT1. Quando a proteína Malx3p estiver ligada ao sítio $U_{\text {UAS }}$, a transcrição deste gene é fortemente induzida (Needleman, 1991). A comparação das seqüências de nucleotídeos do gene $\operatorname{AGT1}$ (1851pb) e de toda a região inter-gênica (785 pb) da linhagem iSUC2 evoluída com as correspondentes sequências na linhagem iSUC2 parental demonstrou que não há um só nucleotídeo de diferença entre as duas linhagens, nesta porção do genoma. Quando uma das cópias do gene $A G T 1$ foi deletada do genoma da linhagem iSUC2 evoluída e a cópia restante do gene $A G T 1$ foi seqüenciada, igualmente não foi observada nenhuma diferença na seqüência de nucleotídeos entre as regiões amplificadas das duas linhagens (dados não apresentados). Em vista destes resultados de sequenciamento, pode-se concluir que mutações pontuais no gene $A G T 1$, ou em sua região promotora, não ocorreram.

\subsubsection{Cultivos descontínuos com a linhagem iSUC2 evoluida}

Para investigar o comportamento do fenótipo evoluído em bateladas com sacarose, uma condição fisiológica bastante diferente dos quimiostatos, e de certa forma mais próxima do processo industrial de produção de etanol, a linhagem iSUC2 evoluída foi cultivada em cultivos descontínuos em anaerobiose plena. Nestes cultivos, ao contrário da linhagem SUC2 (Figura 5.5), as concentrações de glicose e frutose nos cultivos com a linhagem iSUC2 evoluída atingiram os valores máximos de 1,5 e $3 \mathrm{~g} \cdot \mathrm{L}^{-1}$, respectivamente, os 
quais foram ligeiramente superiores aos valores observados na linhagem parental (iSUC2), que não passaram de 1 g.L L $^{-1}$ (Figura 5.5).
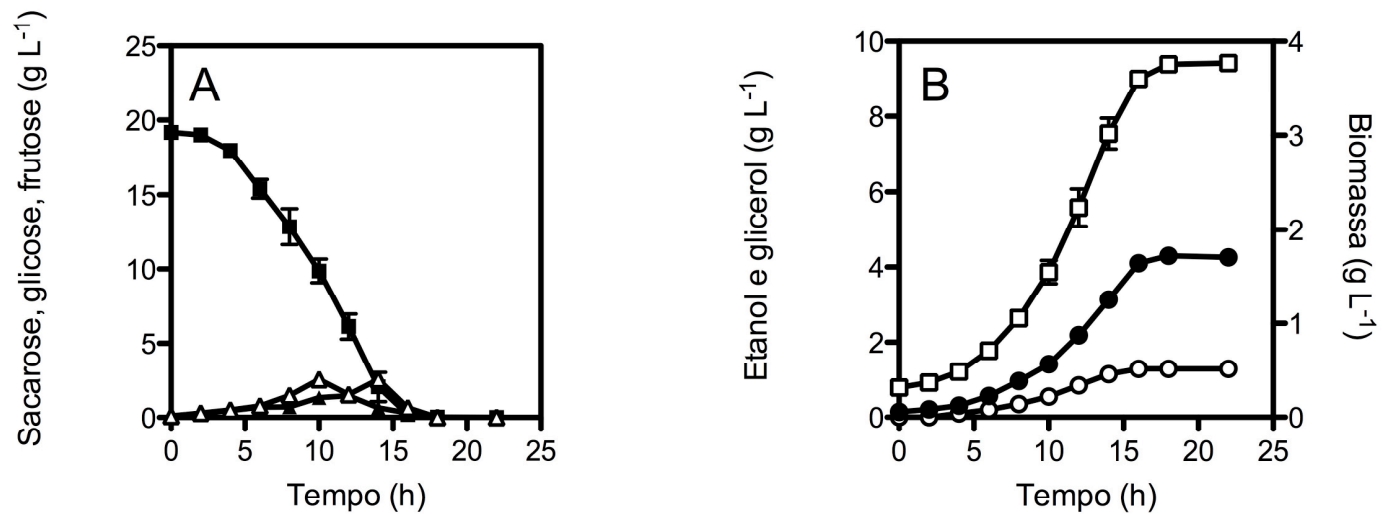

Figura 5.11 - Cultivos descontínuos em anaerobiose plena com a linhagem iSUC2 evoluída. Concentrações de sacarose $(\boldsymbol{\square})$, glicose $(\mathbf{\Delta})$ e frutose $(\triangle)$, (A); e de etanol $(\square)$, glicerol $(O)$ e biomassa celular $(\bullet)$ (B), durante cultivos descontínuos em meio sintético com sacarose a $20 \mathrm{~g} / \mathrm{L}$ iniciais como única fonte de carbono. Os dados apresentados correspondem ao terceiro ciclo de bateladas repetidas conduzidas em duplicata (ver Materiais e Métodos). Os dados estão apresentados como a média \pm o desvio da média de dois experimentos independentes.

O tempo necessário para a exaustão da fonte de carbono diminuiu da linhagem iSUC2 para a iSUC2 evoluída, passando de 20 para 15 h (Figuras 5.11 e 5.5). Isto é refletido num aumento da $q_{s}$ na linhagem evoluída $\left.[16,1 \pm 0,7 \mathrm{mmol} \text { GLC eq.(g DW.h })^{-1}\right]$ em comparação à linhagem iSUC2 [11,1 $\pm 0,2 \mathrm{mmol}$ GLC eq.(g DW.h $\left.)^{-1}\right]$. Com o referido aumento, tal parâmetro na linhagem iSUC2 evoluída se aproximou à $q_{S}$ da linhagem SUC2 $\left[19,4 \pm 0,2 \mathrm{mmol}\right.$ GLC eq. (g DW.h) $\left.{ }^{-1}\right]$. Paralelamente a estes dados, observou-se um aumento na $q_{\mathrm{ETH}}$ da linhagem iSUC2 evoluída [26,5 $\pm 1,2 \mathrm{mmol}$ ETH.(g DW.h $\left.)^{-1}\right]$ em relação à iSUC2 original $\left.[16,9 \pm 2,5 \mathrm{mmol} \text { ETH.(g DW.h })^{-1}\right]$, e assim a $q_{\text {ETH }}$ da linahgem iSUC2 evoluída praticamente se igualou ao mesmo parâmetro da linhagem SUC2 [26,6 + 0,2 mmol ETH.(g DW.h $\left.)^{-1}\right]$.

Além de apresentar uma velocidade específica de produção de etanol semelhante à da linhagem SUC2, o $Y_{\mathrm{ETH} / \mathrm{S}}$ foi $18 \%$ superior na linhagem iSUC2 evoluída em relação à SUC2, passando de 0,350 $\pm 0,004$ para 0,413 $\pm 0,009 \mathrm{~g} \cdot \mathrm{g}^{-1}$. O aumento do $\mathrm{Y}_{\mathrm{ETH} / \mathrm{S}}$ foi acompanhado de um menor rendimento em biomassa, parâmetro que foi de 0,100 $\pm 0,001 \mathrm{~g} \mathrm{DW} \cdot \mathrm{g}^{-1}$ na linhagem SUC2 e 0,081 $\pm 0,004 \mathrm{~g} D W \cdot \mathrm{g}^{-1}$ na linhagem iSUC2 evoluída. No entanto, o tempo necessário para a exaustão da fonte de carbono na linhagem evoluída (15 h) ainda foi maior do que na linhagem selvagem, que consumiu toda a sacarose em cerca de $10 \mathrm{~h}$. 
Com todos estes dados, é possível concluir que os atributos favoráveis da linhagem iSUC2 evoluída, observados em regime de quimiostato, foram igualmente observados em cultivos descontínuos. Além disto, o fenótipo obtido durante a evolução, que foi selecionado num ambiente limitado pela fonte de carbono, aparentemente não apresentou hipersensibilidade (queda de viabilidade) ao ser exposto ao excesso de açúcar, como já observado em seleções semelhantes realizadas em meios contendo glicose (Jansen et al., 2005) ou maltose (Jansen et al., 2004) como substrato limitante. Finalmente, este fenótipo em cultivo descontínuo é uma forte comprovação de que o que ocorreu ao longo do processo de evolução em quimiostato foi mutação e não adaptação.

\subsubsection{Análise do transcriptoma}

A análise do transcriptoma foi realizada por meio de micro-arranjos de oligonucleotídeos, utilizando-se plataforma de canal-único Affymetrix, a partir de amostras coletadas durante o estado-estacionário de cultivos independentes realizados em duplicata para cada uma das três linhagens avaliadas (SUC2, iSUC2 e iSUC2 evoluída).

Quando a linhagem iSUC2 evoluída foi comparada à linhagem iSUC2 em cultivos anaeróbicos limitados por sacarose, foram encontrados 122 genes apresentando um nível de transcrição no mínimo 2 vezes maior na linhagem evoluída, em relação à linhagem parental. Surpreendentemente, não foi identificado nenhum gene com expressão diminuída na linhagem iSUC2 evoluída, em relação à linhagem iSUC2. A análise estatística foi realizada usando o algoritmo SAM ( "Significance Analysis of Microarrays"), conforme descrito no item Materiais e Métodos (item 4.12) e a lista completa dos 122 genes com expressão aumentada na linhagem iSUC2 evoluída encontra-se apresentada no ANEXO A. Alguns genes selecionados, envolvidos no metabolismo da sacarose, são apresentados na Tabela 5.5.

Dentre os 122 genes com expressão aumentada na linhagem iSUC2 evoluída, em relação à linhagem iSUC2, foram identificados vários envolvidos no metabolismo da maltose/sacarose. Foram encontrados tanto genes estruturais, que codificam permeases (AGT1, MAL31, MPH2, MPH3) e maltases (MAL32, FSP2, IMA5, YGR287C) (Teste et al., 2010), como genes que codificam proteínas regulatórias (MAL13). Com isto, observa-se que os loci MAL1 e MAL3 tiveram quase todos os seus genes com expressão aumentada, ao 
compararmos as linhagens iSUC2 evoluída e iSUC2. As únicas exceções foram para os genes MAL33 e YFL052W, os quais não apresentaram alterações significativas de acordo com o algorítimo SAM (Tabela 5.5).

É importante salientar que a linhagem CEN.PK113-7D (da qual origina-se a linhagem iSUC2, bem como a iSUC2 evoluída) possui os loci MAL1 (AGT1 MAL12 mal13), MAL2 (MAL21-22-23) e MAL3 (MAL31-32-33) (Vidgren et al., 2005). No entanto, a linhagem S288C, na qual a plataforma dos micro-arranjos Affymetrix é baseada, apresenta apenas os loci MAL1 e MAL3. Assim sendo, para a interpretação destes dados, deve-se levar em conta que os transcritos relativos aos 3 genes do locus MAL2 podem não ter hibridizado ou podem ter hibridizado com sondas relativas aos genes contidos nos loci MAL1 e MAL3.

O aumento na transcrição dos genes referentes às permeases (Tabela 5.5) foi condizente com o aumento do transporte de sacarose $/ \mathrm{H}^{+}$(Figura 5.7). Como não foi observada nenhuma mutação (item 5.4.3) no gene do transportador de alta-afinidade Agt1p, considerado o principal transportador de sacarose (Stambuk et al., 2000), é provável que o aumento no transporte de sacarose $/ \mathrm{H}^{+}$na linhagem iSUC2 evoluída tenha sido causado pelo aumento do número dos transportadores na membrana plasmática, decorrente da duplicação deste gene, o que significa um aumento na capacidade de transporte e não na afinidade. Adicionalmente, a regulação da expressão do gene e/ou a degradação deste transportador podem ter sido alteradas durante a evolução. Portanto, é pouco provável que o aumento do transporte de sacarose na linhagem evoluída seja fruto de alterações na constante de saturação do substrato $\left(K_{\mathrm{m}}\right)$ da proteína Agt1p. Esta hipótese é suportada pelo aumento de 4 vezes na expressão deste gene, passando de 861 para 3369 unidades arbitrárias, ao se comparar a linhagem iSUC2 com a linhagem iSUC2 evoluída (Tabela 5.5). Apesar de outros genes, que codificam transportadores de alfa-glicosídeos (MAL31, MPH2 e MPH3) terem apresentado expressão aumentada na linhagem iSUC2 evoluída, apenas o transportador Mal31p é apontado com sendo capaz de transportar sacarose. No entanto, este transporte é de baixa afinidade $(120 \mathrm{mM})$ e baixa capacidade, segundo Badotti et al. (2008). Em relação às proteínas Mph2p e Mph3p, não existem estudos demonstrando se as mesmas são capazes de transportar sacarose (Day et al., 2002).

Para confirmar que a melhoria do transporte de sacarose na linhagem iSUC2 evoluída realmente ocorreu pelo aumento da capacidade de transporte, e não pelo aumento da afinidade, alguns parâmetros cinéticos $\left(V_{\max }\right.$ e $\left.K_{\mathrm{m}}\right)$ do transporte de sacarose das linhagens 
iSUC2 e iSUC2 evoluída foram estimados por meio do co-transporte com $\mathrm{H}^{+}$. As células foram coletadas durante a fase exponencial de crescimento em meio YP com sacarose a $2 \%(p / v)$ e avaliadas quanto às cinéticas de transporte de sacarose. Os dados da cinética de transporte da linhagem iSUC2 foram condizentes com os dados publicados na literatura (Badotti et al., 2008; Stambuk et al., 2000), apresentando $K_{\mathrm{m}}$ ao redor de $6 \mathrm{mM}$ e um $V_{\max }$ de $70,4 \mathrm{nmol}$.(g DW.min) ${ }^{-1}$. Como havia sido previamente suspeitado, verificou-se que somente o $V_{\max }$ foi alterado na linhagem iSUC2 evoluída, sendo este parâmetro de 227,3 nmol.(g DW.h.' ${ }^{-1}$, enquanto o $k_{\mathrm{m}}(\sim 5,5 \mathrm{mM})$ manteve-se praticamente inalterado em relação à linhagem iSUC2. As diferenças observadas entre os dados de transporte obtidos nos cultivos em quimiostato (Figura 5.7) e os dados de $V_{\max }$ estimados em meio rico (Figura 5.12) podem ser explicadas pelas distintas condições fisiológicas das células no momento das análises.

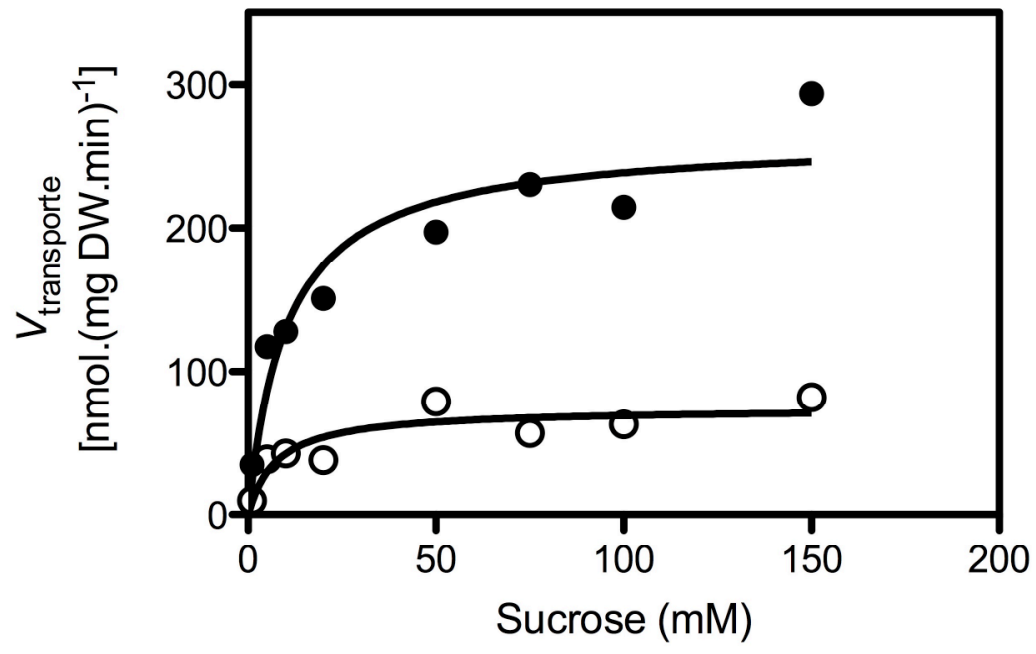

Figura 5.12 - Cinéticas de transporte de sacarose para as linhagens iSUC2 (O) e iSUC2 evoluída (•). As células foram coletadas na fase exponencial de crescimento em frasco agitado em meio YP com sacarose a $2 \%(\mathrm{p} / \mathrm{v})$. Os dados referem-se a medidas únicas do co-transporte com $\mathrm{H}^{+}$, provenientes de um único cultivo. Os parâmetros $V_{\max }$ e $K_{\mathrm{m}}$ foram calculados pelo método de Lineweaver e Burk.

Assim, conclui-se que o elevado teor de sacarose residual durante os quimiostatos com a linhagem iSUC2 é provavelmente fruto de uma capacidade saturada de transporte (ou seja, limitado pelo $V_{\max }$ ) e não de uma baixa afinidade dos transportadores pela sacarose (resultante de um valor de $K_{\mathrm{m}}$ eleveado). Assim, pode-se especular que, durante a evolução, o aumento no $V_{\max }$ ocorreu através do aumento do número de transportadores na membrana plasmática. Esta explicação é reforçada pelo fato de que nos cultivos aeróbicos limitados por sacarose com a linhagem iSUC2 ura-, a concentração de sacarose residual no 
estado-estacionário foi de apenas $0,03 \mathrm{~g} \cdot \mathrm{L}^{-1}$ (Tabela 5.3). Nesta condição, a $q_{\mathrm{s}}$, que em teoria se iguala à $V_{\text {transporte }}$ (Jansen et al., 2004), foi de $1,1 \mathrm{mmol} \mathrm{GLC} \mathrm{eq.(g} \mathrm{DW.h)-1}{ }^{-1}$, enquanto que nos cultivos anaeróbicos em sacarose o mesmo parâmetro foi de 6,0 mmol GLG eq.(g DW.h) ${ }^{1}$. Portanto, um aumento no $V_{\max }$ do Agt1p justificaria uma diminuição na concentração de sacarose $\left(0,08 \mathrm{~g} \cdot \mathrm{L}^{-1}\right)$, observada nos cultivos anaeróbicos limitados por sacarose com a linhagem iSUC2 evoluída.

Além do aumento da expressão das permeases para alfa-glicosídeos (MAL11, MAL31, MPH3 e MPH2), também foram identificados genes relacionados ao transporte de hexoses (HXT8, HXT9 e HXT12) (Ozcan e Johnston, 1999), os quais podem ter contribuído para os baixos níveis de glicose $\left(<0,01\right.$ g. $\mathrm{L}^{-1} ;$ Tabela 5.4$)$ durante o estado-estacionário nos cultivos com a linhagem iSUC2 evoluída. Uma constatação interessante foi o fato de que os genes HXT8 e HXT9 não foram expressos na linhagem iSUC2 (nível de transcrição igual a 12), mas passaram a ser expressos na linhagem iSUC2 evoluída (nível de transcrição de 297 para o gene $H X T 8$ e 92 para o gene $H X T 9)$.

Apesar do aumento na transcrição dos genes que codificam maltases (alfaglicosidases), as quais são capazes de hidrolisar a sacarose (Needleman, 1991; Badotti et al., 2008), que é um $\alpha$-D-Glucopiranosideo, $\beta$-D-fructofuranosil, não foi observada diferença nos níveis de expressão do gene $S U C 2$, que codifica a enzima invertase, entre as linhagens iSUC2 evoluída e iSUC2 (Tabela 5.5). A medida da atividade de invertase, durante os cultivos com estas duas linhagens, gerou resultados muito próximos entre si (Figura 5.4). Estes resultados indicam que a expressão e a atividade da invertase não foram afetadas pelo processo de evolução em biorreator.

Outro gene que poderia ter sido alterado na evolução seria o gene $P M A 1$, o qual codifica a $\mathrm{H}^{+}$-ATPase de membrana, que bombeia $\mathrm{H}^{+}$para fora das células através da clivagem de ATP (Ambesi et al., 2000; Serrano et al., 1986). No entanto, apesar de altamente expresso nas duas linhagens (níveis de transcrição ao redor de 1700 unidades arbitrárias), não foram observadas diferenças de expressão entre as mesmas.

A ferramenta "The hypergeometric distribution analyser" (HGD) foi utilizada para avaliar possíveis categorias funcionais de genes que estivessem sobre-representadas no conjunto dos genes com expressão aumentada (Knijnenburg et al., 2007). Foram encontradas as seguintes categorias funcionais, de acordo com o modo de classificação "Gene Ontology": disaccharide metabolic process, maltose metabolic process, 
oligosaccharide metabolic process, carbohydrate metabolic process, cellular carbohydrate metabolic process, response to stress, carbohydrate transport. De todas estas categorias funcionais, a única que não é óbvia é a de resposta ao estresse. De fato, notam-se vários genes do tipo "Heat-Shock Protein" na Tabela 5.5. No entanto, não temos uma explicação para esta observação e também não se buscou, neste trabalho, entender as causas para a super-representação desta categoria funcional no grupo de genes que tiveram expressão aumentada na linhagem iSUC2 evoluída, em relação à linhagem iSUC2.

Quando os níveis dos transcritos na linhagem iSUC2 foram comparados aos da linhagem-referência SUC2 (CEN.PK113-7D), amostradas durante o estado estacionário de quimiostatos anaeróbicos limitados por sacarose, foram encontrados apenas 9 genes com um nível de transcrição no mínimo 2 vezes menor na linhagem iSUC2, em relação à linhagem CEN.PK113-7D (Tabela 5.6). Não foi identificado nenhum gene com expressão significativamente aumentada (no mínimo 2 vezes) na linhagem iSUC2, em relação à linhagem SUC2.

O gene SUC2, que codifica a enzima invertase, apresentou expressão de 1660 unidades arbitrárias na linhagem-referência (SUC2) e de 3141 unidades arbitrárias na linhagem iSUC2. Apesar de não estar significativamente com expressão aumentada (razão de aumento de expressão menor do que 2 vezes), estes resultados estão condizentes com o nível da atividade de invertase total nestas duas leveduras, que foram de 2133 e 4726 nmol.(mg DW.min $)^{-1}$ nas linhagens SUC2 e iSUC2, respectivamente, indicando também que a regulação da expressão deste gene é fundamentalmente transcricional. Cabe ressaltar que a análise por microarranjo de DNA não é capaz de diferenciar entre os dois transcritos que codificam a invertase extracelular e intracelular.

Considerando-se este número muito baixo de genes que tiveram sua expressão alterada na linhagem iSUC2, em relação à linhagem SUC2, pode-se afirmar que a modificação genética realizada na linhagem-referência, nomeadamente a modificação do gene SUC2 através da eliminação da sequência sinal de secreção e da introdução de um promotor forte $\left(\mathrm{P}_{A D H 1}\right)$ para promover a expressão do gene (Stambuk et al, 2009), não resultou em outras alterações importantes no metabolismo da levedura, o que é desejável. Além disto, estes resultados também atestam a reprodutibilidade da análise de transcriptoma, já que a expressão de mais de 6000 genes é interrogada por esta metodologia. 
Tabela 5.5 - Lista de alguns genes (envolvidos no metabolismo de sacarose) com expressão aumentada na linhagem iSUC2 evoluída em relação à iSUC2, durante o estado-estacionário de quimiostatos anaeróbicos limitados por sacarose.

\begin{tabular}{|c|c|c|c|c|c|c|}
\hline \multicolumn{2}{|c|}{ Gene } & \multirow[b]{2}{*}{$\begin{array}{l}\text { (Nome sistemático com breve } \\
\text { descrição obtida da base de dados } \\
\text { SGD) }\end{array}$} & \multicolumn{2}{|c|}{$\begin{array}{l}\text { Níveis dos } \\
\text { transcritos } \\
\text { (unidades } \\
\text { arbitrárias) }\end{array}$} & \multirow{2}{*}{$\begin{array}{c}\begin{array}{c}\text { Aumento } \\
\text { da }\end{array} \\
\text { expressão } \\
\text { (iSUC2 } \\
\text { evoluída vs } \\
\text { iSUC2) }\end{array}$} & \multirow[t]{2}{*}{ Enzima } \\
\hline $\begin{array}{l}\text { (Nome } \\
\text { padrão) }\end{array}$ & $\begin{array}{c}\text { (Nome } \\
\text { sistemático) }\end{array}$ & & iSUC2 & $\begin{array}{l}\text { iSUC2 } \\
\text { evoluí } \\
\text { da }\end{array}$ & & \\
\hline $\begin{array}{l}\text { MAL11 } \\
\text { (AGT1) }\end{array}$ & YGR289C & $\begin{array}{l}\text { YGR289C alpha-glucoside } \\
\text { transporter }\end{array}$ & 861 & 3369 & 3,9 & \multirow{4}{*}{ permease } \\
\hline MAL31 & YBR298C & YBR298C maltose permease & 217 & 1444 & 6,6 & \\
\hline МРH3 & YJR160C & YJR160C strong similarity to Mal31p & 24 & 427 & 17,4 & \\
\hline MPH2 & YDL247W & $\begin{array}{l}\text { YDL247W strong similarity to sugar } \\
\text { transport proteins }\end{array}$ & 23 & 395 & 16,7 & \\
\hline$H X T 2$ & & $\begin{array}{l}\text { YMR011W high affinity hexose } \\
\text { transporter-2 }\end{array}$ & 184 & 434 & 2,4 & \multirow{4}{*}{ permease } \\
\hline HXT8 & YJL214W & $\begin{array}{l}\text { YJL214W High-affinity hexose } \\
\text { transporter }\end{array}$ & 12 & 297 & 24,8 & \\
\hline HXT12 & YIL171W & $\begin{array}{l}\text { YIL171W High-affinity hexose } \\
\text { transporter }\end{array}$ & 26 & 107 & & \\
\hline HXT9 & YJL219W & $\begin{array}{l}\text { YJL219W High-affinity hexose } \\
\text { transporter }\end{array}$ & 12 & 82 & 6,8 & \\
\hline MAL32 & YBR299W & YBR299W Maltase (EC 3.2.1.20) & 1472 & 3806 & 2,6 & \multirow{4}{*}{ maltase } \\
\hline \multirow[t]{2}{*}{ FSP2 } & YJL221C & $\begin{array}{l}\text { YJL221C homology to maltase(alpha- } \\
\text { D-glucosidase) }\end{array}$ & 275 & 1736 & 6,3 & \\
\hline & YGR287C & $\begin{array}{l}\text { YGR287C strong similarity to } \\
\text { maltase }\end{array}$ & 153 & 477 & 3,1 & \\
\hline IMA5 & YJL216C & YJL216C strong similarity to Mal62p & 12 & 331 & 27,6 & \\
\hline \multirow[t]{2}{*}{ MAL13 } & YGR288W & $\begin{array}{l}\text { YGR288W maltose pathway } \\
\text { regulatory protein }\end{array}$ & 48 & 513 & 10,5 & \multirow{3}{*}{$\begin{array}{c}\text { proteína } \\
\text { de } \\
\text { regulação } \\
\text { positiva }\end{array}$} \\
\hline & YFL052W & $\begin{array}{l}\text { YFL052W strong similarity to } \\
\text { Mal63p, YPR196w and Mal13p }\end{array}$ & 49 & 87 & 1,7 & \\
\hline MAL33 & YBR297W & $\begin{array}{l}\text { YBR297W Maltose fermentation } \\
\text { regulatory protein }\end{array}$ & 433 & 355 & $-1,2$ & \\
\hline SUC2 & YIL162W & $\begin{array}{l}\text { YIL162W invertase (sucrose } \\
\text { hydrolyzing enzyme) }\end{array}$ & 3141 & 3262 & 1,0 & invertase \\
\hline
\end{tabular}


Tabela 5.6 - Lista dos 9 genes com expressão diminuida na linhagem iSUC2 em relação à SUC2 (linhagemrefeência), durante o estado-estacionário de quimiostatos anaeróbicos limitados por sacarose.

\begin{tabular}{|c|c|c|c|c|c|}
\hline \multicolumn{2}{|c|}{ Gene } & \multirow[b]{2}{*}{$\begin{array}{l}\text { (Nome sistemático com breve } \\
\text { descrição obtida da base de dados } \\
\text { SGD) }\end{array}$} & \multicolumn{2}{|c|}{$\begin{array}{l}\text { Níveis dos transcritos } \\
\text { (unidades arbitrárias) }\end{array}$} & \multirow{2}{*}{ 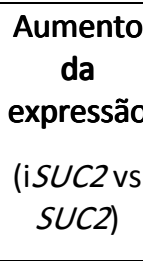 } \\
\hline $\begin{array}{l}\text { (Nome } \\
\text { padrão) }\end{array}$ & $\begin{array}{c}\text { (Nome } \\
\text { sistemático) }\end{array}$ & & SUC2 & iSUC2 & \\
\hline \multirow[t]{2}{*}{ INO1 } & YJL153C & $\begin{array}{l}\text { YJL153C L-myo-inositol-1- } \\
\text { phosphate synthase }\end{array}$ & 1923 & 74 & $-2,6$ \\
\hline & YBR056W & $\begin{array}{l}\text { YBR056W Homolog to glucan-1,3-- } \\
\text { glucosidase (EC 3.2.1.5 } \backslash \text { S. } \\
\text { cerevisiae) }\end{array}$ & 62 & 24 & $-2,6$ \\
\hline TFS1 & YLR178C & YLR178C suppressor of cdc25 & 352 & 174 & $-2,0$ \\
\hline \multirow[t]{2}{*}{ CrC7 } & YEL039C & YEL039C iso-2-cytochrome c & 118 & 58 & $-2,0$ \\
\hline & YML083C & YML083C hypothetical protein & 53 & 23 & $-2,2$ \\
\hline ECM4 & YKR076W & YKR076W ExtraCellular Mutant & 94 & 43 & $-2,2$ \\
\hline \multirow[t]{3}{*}{ THI21 } & YPL258C & $\begin{array}{l}\text { YPL258C similarity to B.subtilis } \\
\text { transcriptional activator tenA, and } \\
\text { strong similarity to hypothetical } \\
\text { proteins YOL055c and YPR } 121 \mathrm{w}\end{array}$ & 51 & 21 & $-2,5$ \\
\hline & YDL158C & YDL158C questionable ORF & 127 & 28 & $-4,5$ \\
\hline & YLR456W & $\begin{array}{l}\text { YLR456W strong similarity to } \\
\text { YPR172w }\end{array}$ & 56 & 25 & $-2,2$ \\
\hline
\end{tabular}




\section{CONCLUSÕES}

Os resultados apresentados no presente trabalho permitem concluir que:

\subsection{Efeito da limitação por uracila em cultivos contínuos}

6.1.1. A limitação pela uracila, em cultivos contínuos aeróbicos com células de $S$. cerevisiae auxotróficas para este nutriente, resulta em uma drástica alteração do metabolismo celular, quando comparada à limitação exclusiva pela fonte de carbono. Nesta situação, i) ocorre diminuição do fator de conversão de substrato a células, ii) desvio do carbono para a formação de etanol e acetato, e iii) crescimento celular limitado simultaneamente pela fonte de carbono e pelo nutriente auxotrófico (Basso et al., 2010).

\subsection{Impactos fisiológicos oriundos da relocalização da enzima invertase}

6.2.1. A estratégia de engenharia metabólica, cujo propósito foi o de aumentar o fator de conversão de sacarose em etanol $\left[\mathrm{Y}_{\mathrm{ETH} / \mathrm{S}}\left(\mathrm{g}\right.\right.$ etanol g sacarose $\left.\left.{ }^{-1}\right)\right]$ na levedura $S$. cerevisiae, através da eliminação da atividade de invertase extracelular e da superexpressão da forma intracelular desta enzima (linhagem iSUC2), desenvolvida por Stambuk et al. (2009), foi eficaz, resultando em $4 \%$ de aumento no $Y_{E T H / S}$, com uma concomitante diminuição de 4,5\% no $Y_{X / S}$, o que foi determinado durante o estado-estacionário de quimiostatos anaeróbicos limitados por sacarose. Adicionalmente, a atividade de invertase total na linhagem iSUC2 foi cerca de 2 vezes maior do que na linhagem SUC2. Entretanto, na levedura iSUC2 a invertase passou a ser predominantemente intracelular, ao contrário da levedura SUC2, que foi predominantemente extracelular. Apesar desta melhoria nos parâmetros fisiológicos, observou-se uma alta concentração residual de sacarose $\left(1,8 \mathrm{~g} \cdot \mathrm{L}^{-1}\right)$ nestes experimentos e as variações observadas em $Y_{E T H / S}$ e $Y_{X / S}$ estiveram aquém das variações que se poderia obter ( $+8 \%$ e $-25 \%$, respectivamente), segundo previsões de um modelo metabólico teórico para o crescimento de $S$. cerevisiae em anaerobiose;

6.2.2. Os resultados descritos em 6.2.1. podem ser explicados por uma limitada capacidade (e não afinidade) de transporte de sacarose na linhagem iSUC2, o que foi 
comprovado por medidas de transporte de sacarose realizadas tanto com esta linhagem, como com a linhagem iSUC2 evoluída, na qual esta limitação foi contornada. Os dados demonstram que o $V_{\max }$ aumentou na linhagem iSUC2 evoluída, em relação à linhagem iSUC2, enquanto o parâmetro $K_{\mathrm{m}}$ permaneceu o mesmo. O fato de a velocidade específica máxima de crescimento em sacarose na linhagem iSUC2 ter diminuído 40 e 50\% (em frasco agitado e em cultivo descontínuo em anaerobiose, respectivamente), em relação ao fenótipo selvagem, corrobora esta constatação;

6.2.3. A interrupção do gene $A G T 1$ na linhagem iSUC2 aumentou em $30 \%$ e em $100 \%$ o tempo necessário para a exaustão da sacarose em cultivos descontínuos anaeróbicos, em relação às linhagens iSUC2 e SUC2, respectivamente. Esta observação comprova o papel determinante do gene $A G T 1$ no metabolismo da sacarose, principalmente em linhagens que não expressam a invertase extracelular. Por outro lado, a remoção do mesmo gene na linhagem SUC2 não causou alteração no metabolismo da sacarose, o que demonstra/comprova que em linhagens selvagens a via principal de hidrólise de sacarose é a extracelular;

6.2.4. A modificação genética introduzida por Stambuk et al. (2009) na linhagem CEN.PK113-7D (SUC2), no sentido de relocalizar o metabolismo da sacarose em S. cerevisiae, não gerou alterações importantes no transcriptoma desta levedura (somente 9 genes tiveram sua expressão significativamente diminuída na linhagem iSUC2, em relação à linhagem SUC2), determinado durante o estado-estacionário de quimiostatos anaeróbicos limitados por sacarose.

\subsection{Aplicação da engenharia evolutiva como estratégia para o melhoramento do transporte ativo de sacarose}

6.3.1. A estratégia de engenharia evolutiva empregada - quimiostatos longos limitados por sacarose, em anaerobiose - mostrou-se adequada para a obtenção de um mutante (a partir da linhagem iSUC2) que apresentou um aumento de 20 vezes na capacidade de transporte de sacarose, resultando na diminuição drástica da concentração residual de sacarose no biorreator, em relação à linhagem iSUC2;

6.3.2. A linhagem obtida (iSUC2 evoluída) apresentou todos os parâmetros fisiológicos de interesse (fatores de conversão de substrato a etanol, e de substrato a 
células, bem como as velocidades específicas de consumo de sacarose e de formação de etanol) muito próximos aos valores calculados pelo modelo metabólico. Comparando-se a linhagem iSUC2 evoluída com a linhagem-referência (SUCZ), em quimiostatos conduzidos em anaerobiose, limitados por sacarose, foi observado um aumento de $11 \%$ no $\mathrm{Y}_{\mathrm{ETH} / \mathrm{s}}$ e uma diminuição de $27 \%$ no $Y_{x / S}$ (as variações previstas pelo modelo metabólico são de + $8 \%$ e $25 \%$, respectivamente);

6.3.3. A duplicação do gene $A G T 1$, juntamente com o aumento da expressão dos genes relacionados ao transporte de dissacarídeos (MPH2, MPH3, MAL11, MAL31) e hexoses (HXT8, HXT9, HXT12), parece ter sido os fatores responsáveis pelo novo fenótipo obtido, através da estratégia de evolução utilizada no presente estudo. Não houve mutações na sequência do gene $A G T 1$;

6.3.4. Eliminando-se as duas cópias do gene $A G T 1$ na linhagem iSUC2 evoluída, foi possível restaurar um fenótipo que corresponde a uma combinação dos fenótipos da linhagem-referência CEN.PK113-7D (SUC2) e da linhagem iSUC2, já que parâmetros como $\mathrm{Y}_{\mathrm{ETH} / \mathrm{S}}, \mathrm{Y}_{\mathrm{X} / \mathrm{S}}$ e $q_{\mathrm{ETH}}$ na linhagem iSUC2 evoluída $\Delta / \Delta$ agt1 ficaram mais próximos dos parâmetros observados para a linhagem SUC2, mas a concentração residual de sacarose nos quimiostatos anaeróbios limitados por sacarose ficaram mais próximos dos valores observados para a linhagem iSUC2. Deletando-se apenas uma cópia do gene AGT1 na linhagem iSUC2 evoluída, isto não foi observado;

6.3.5. Superexpressando-se o gene $A G T 1$ na linhagem iSUC2, conseguiu-se gerar uma linhagem que apresentou $Y_{E T H / S}$ muito próximo ao da linhagem iSUC2 evoluída. No entanto, outros parâmetros fisiológicos, calculados para células crescendo em quimiostatos anaeróbios limitados por sacarose, foram diferentes nestas duas linhagens, indicando que a duplicação do gene $A G T 1$ não foi a única mutação que ocorreu durante o processo de evolução em quimiostato.

\subsection{Sugestões para continuidade do trabalho}

- O presente trabalho conseguiu gerar uma linhagem de $S$. cerevisiae com fator de conversão de sacarose a etanol $11 \%$ maior que a linhagem-referência. Para que se possa pensar na aplicação industrial desta estratégia, alguns passos adicionais são necessários, dos quais se destaca: estudo da fisiologia da linhagem melhorada em cultivos que simulam as 
condições industriais (com meios de cultura industriais, em processo descontínuoalimentado com reciclo de células e tratamento ácido entre as bateladas alimentadas); introdução da mesma estratégia de engenharia metabólica combinada com engenharia evolutiva em linhagens industriais consagradas, como PE-2, CAT-1 e BG-1 (Basso et al., 2008).

- Para entender porque a introdução de cópias adicionais do gene AGT1 na linhagem iSUC2 não gerou exatamente o mesmo fenótipo obtido durante a evolução em quimiostato, seria interessante sequenciar todo o genoma da linhagem iSUC2 evoluída, de forma a se verificar quais outras alterações genéticas ocorreram nesta linhagem, durante a evolução. Cabe lembrar que a sequência do genoma da linhagem-referência CEN.PK113-7D (Van Dijken et al., 2000), apesar de ainda não estar publicamente disponível, deverá ser disponibilizada em breve para a comunidade científica. 


\section{REFERÊNCIAS ${ }^{3}$}

Abbott DA, Knijnenburg TA, de Poorter LMI, Reinders MJT, Pronk JT, van Maris AJA. Generic and specific transcriptional responses to different weak organic acids in anaerobic chemostat cultures of Saccharomyces cerevisiae. FEMS Yeast Res. 2007;7:819-33.

Abbott DA, Suir E, Duong GH, de Hulster E, Pronk JT, van Maris AJA. Catalase Overexpression Reduces Lactic Acid-Induced Oxidative Stress in Saccharomyces cerevisiae. Appl Environ Microbiol. 2009;75:2320-5.

Ambesi A, Miranda M, Petrov VV, Slayman CW. Biogenesis and function of the yeast plasmamembrane $\mathrm{H}^{+}$-ATPase. J Exp Biol. 2000;203:155-60.

Araya CL, Payen C, Dunham MJ, Fields S. Whole-genome sequencing of a laboratory-evolved yeast strain. BMC Genomics.2010;11:88-97.

Avigad G. Accumulation of trehalose and sucrose in relation to the metabolism of alphaglucosides in yeasts of defined genotype. Biochim Biophys Acta. 1960;40:124-34.

Badotti F, Batista AS, Stambuk BU. Sucrose active transport and fermentation be Saccharomyces cerevisiae. Brazilian Archives of Biology and Technology. 2006;49:115-23.

Badotti F, Dario MG, Alves SL, Cordioli MLA, Miletti LC, de Araujo PS, et al. Switching the mode of sucrose utilization by Saccharomyces cerevisiae. Microbial Cell Factories. 2008;7:414.

Barford JP, Johnston JH, Mwesigye PK. Continuous-culture study of transient-behavior of saccharomyces-cerevisiae growing on sucrose and fructose. J Ferment Bioeng. 1995;79:15862.

Basso LC, de Amorim HV, de Oliveira AJ, Lopes ML. Yeast selection for fuel ethanol production in Brazil. FEMS Yeast Res. 2008;8:1155-63.

\footnotetext{
${ }^{3}$ De acordo com: International Committee of Medical Journal Editors. Uniform requirements for manuscripts submitted to Biomedical Journal: sample references. Avaiable from: http://www.icmj.org [2007 May 22].
} 
Basso TO, Dario MG, Tonso A, Stambuk BU, Gombert AK. Insufficient uracil supply in fully aerobic chemostat cultures of Saccharomyces cerevisiae leads to respiro-fermentative metabolism and double nutrient-limitation. Biotechnol Lett. 2010;32:973-7.

Batista AS, Miletti LC, Stambuk BU. Sucrose fermentation by Saccharomyces cerevisiae lacking hexose transport. J Mol Microbiol Biotechnol. 2004;8:26-33.

Becker J, Boles E. A modified Saccharomyces cerevisiae strain that consumes L-arabinose and produces ethanol. Appl Environ Microbiol. 2003;69:4144-50.

Benito B, Lagunas R. The low-affinity component of saccharomyces-cerevisiae maltose transport is an artifact. J Bacteriol. 1992;174:3065-9.

Boer V, de Winde J, Pronk J, Piper M. Transcriptional responses of Saccharomyces cerevisiae to limitations of carbon, nitrogen, phosphorus or sulfur. Yeast. 2003;20:S333-S.

Boer VM, Amini S, Botstein D. Influence of genotype and nutrition on survival and metabolism of starving yeast. PROC NATL ACAD SCI U S A. 2008;105:6930-5.

Boles $\mathrm{E}$, Hollenberg CP. The molecular genetics of hexose transport in yeasts. FEMS Microbiol Rev. 1997;21:85-111.

Brauer MJ, Huttenhower C, Airoldi EM, Rosenstein R, Matese JC, Gresham D, et al. Coordination of growth rate, cell cycle, stress response, and metabolic activity in yeast. Molecular Biology of the Cell. 2008;19:352-67.

Bro C, Regenberg B, Forster J, Nielsen J. In silico aided metabolic engineering of Saccharomyces cerevisiae for improved bioethanol production. Metab Eng. 2006;8:102-11.

Brondijk THC, van der Rest ME, Pluim D, de Vries Y, Stingl K, Poolman B, et al. Catabolite inactivation of wild-type and mutant maltose transport proteins in Saccharomyces cerevisiae. J Biol Chem. 1998;273:15352-7.

Brown CJ, Todd KM, Rosenzweig RF. Multiple duplications of yeast hexose transport genes in response to selection in a glucose-limited environment. Mol Biol Evol. 1998;15:931-42. 
Brown SW, Oliver SG. Isolation of ethanol-tolerant mutants of yeast by continuous selection. European Journal of Applied Microbiology and Biotechnology. 1982;16:119-22.

Button DK. Biochemical Basis for whole-cell uptake kinetics - specific affinity, oligotrophic capacity, and the meaning of the Michaelis constant. Appl Environ Microbiol. 1991;57:20338.

Cakar ZP, Sauer U, Bailey JE. Metabolic engineering of yeast: the perils of auxotrophic hosts. Biotechnol Lett. 1999;21:611-6.

Carlson M, Botstein D. Two differentially regulated mRNAs with different 5 ' ends encode secreted with intracellular forms of yeast invertase. Cell. 1982;28:145-54.

Carlson M, Botstein D. Organization of the SUC gene family in Saccharomyces. Mol Cell Biol. 1983;3:351-9.

Carlson M, Taussig R, Kustu S, Botstein D. The secreted form of invertase in Saccharomyces cerevisiae is synthesized from mRNA encoding a signal sequence. Mol Cell Biol. 1983;3:43947.

Cereghino GP, Scheffler IE. Genetic analysis of glucose regulation in Saccharomyces cerevisiae: control of transcription versus mRNA turnover. EMBO J. 1996;15:363-74.

Charron MJ, Michels CA. The naturally-occurring alleles of MAL1 in saccharomyces species evolved by various mutagenic processes including chromosomal rearrangement. Genetics. 1988;120:83-93.

Cheng $\mathrm{Q}$, Michels CA. MAL11 and MAL61 encode the inducible high-affinity maltose transporter of Saccharomyces cerevisiae. J Bacteriol. 1991;173:1817-20.

Chow THC, Sollitti P, Marmur J. Structure of the multigene family of MAL loci in Saccharomyces. Mol Gen Genetics. 1989;217:60-9.

Corbacho I, Teixido F, Velazquez R, Hernandez LM, Olivero I. Standard YPD, even supplemented with extra nutrients, does not always compensate growth defects of Saccharomyces cerevisiae auxotrophic strains. Antonie Van Leeuwenhoek. 2011;99:591-600. 
Day RE, Higgins VJ, Rogers PJ, Dawes IW. Characterization of the putative maltose transporters encoded by YDL247w and YJR160c. Yeast. 2002;19:1015-27.

De Nicola R, Hazelwood LA, De Hulster EAF, Walsh MC, Knijnenburg TA, Reinders MJT, et al. Physiological and transcriptional responses of Saccharomyces cerevisiae to zinc limitation in chemostat cultures. Appl Environ Microbiol. 2007;73:7680-92.

Diderich JA, Schepper M, van Hoek P, Luttik MAH, van Dijken JP, Pronk JT, et al. Glucose uptake kinetics and transcription of HXT genes chemostat cultures of Saccharomyces cerevisiae. J Biol Chem. 1999;274:15350-9.

Ferea TL, Botstein D, Brown PO, Rosenzweig RF. Systematic changes in gene expression patterns following adaptive evolution in yeast. Proc Natl Acad Sci U S A. 1999;96:9721-6.

Frick O, Wittmann C. Characterization of the metabolic shift between oxidative and fermentative growth in Saccharomyces cerevisiae by comparative C-13 flux analysis. Microbial Cell Factories. 2005;4:16.

Galazka JM, Tian CG, Beeson WT, Martinez B, Glass NL, Cate JHD. Cellodextrin transport in yeast for improved biofuel production. Science. 2010;330:84-6.

Gancedo JM. Carbon Catabolite Repression in Yeast. Eur J Biochem. 1992;206:297-313.

Gascon S, Lampen JO. Purification of the internal invertase of yeast. J Biol Chem. 1968;243:1567-72.

Gietz RD, Schiestl RH. Transforming yeast with DNA. Methods Mol Cell Biol. 1995;5:255-69.

Gresham D, Desai MM, Tucker CM, Jenq HT, Pai DA, Ward A, et al. The repertoire and dynamics of evolutionary adaptations to controlled nutrient-limited environments in yeast. PLoS Genet. 2008;4:e1000303.

Gresham D, Usaite R, Germann SM, Lisby M, Botstein D, Regenberg B. Adaptation to diverse nitrogen-limited environments by deletion or extrachromosomal element formation of the GAP1 locus. Proc Natl Acad Sci USA.2010; 107:18551-6. 
Grossmann MK, Zimmermann FK. Structural genes of internal invertases in Saccharomyces cerevisiae. Mol Gen Genetics. 1979;175:223-9.

Guadalupe Medina V, Almering MJ, van Maris AJ, Pronk JT. Elimination of glycerol production in anaerobic cultures of a Saccharomyces cerevisiae strain engineered to use acetic acid as an electron acceptor. Appl Environ Microbiol. 2010;76:190-5.

Guo ZP, Zhang LA, Ding ZY, Shi GY. Minimization of glycerol synthesis in industrial ethanol yeast without influencing its fermentation performance. Metab Eng. 2011;13:49-59.

Han EK, Cotty F, Sottas C, Jiang H, Michels CA. Characterization of AGT1 encoding a general alpha-glucoside transporter from Saccharomyces. Mol Microbiol. 1995;17:1093-107.

Hazelwood LA, Walsh MC, Luttik MAH, Daran-Lapujade P, Pronk JT, Daran JM. Identity of the growth-limiting nutrient strongly affects storage carbohydrate accumulation in anaerobic chemostat cultures of Saccharomyces cerevisiae. Appl Environ Microbiol. 2009;75:6876-85.

$\mathrm{Hu}$ Z, Nehlin JO, Ronne H, Michels CA. MIG1-dependent and MIG1-independent glucose regulation of mal gene-expression in Saccharomyces cerevisiae. Curr Genet. 1995;28:258-66.

Jansen ML, Daran-Lapujade P, de Winde JH, Piper MD, Pronk JT. Prolonged maltose-limited cultivation of Saccharomyces cerevisiae selects for cells with improved maltose affinity and hypersensitivity. Appl Environ Microbiol. 2004;70:1956-63.

Jansen ML, Diderich JA, Mashego M, Hassane A, de Winde JH, Daran-Lapujade P, et al. Prolonged selection in aerobic, glucose-limited chemostat cultures of Saccharomyces cerevisiae causes a partial loss of glycolytic capacity. Microbiology. 2005;151:1657-69.

Jespersen L, Cesar LB, Meaden PG, Jakobsen M. Multiple alpha-glucoside transporter genes in brewer's yeast. Appl Environ Microbiol. 1999;65:450-6.

Johnston JH, Barford JP. Continuous growth of Saccharomyces cerevisiae on a mixture of glucose and fructose. J Gen Appl Microbiol. 1991;37:133-40. 
Klaassen $\mathrm{P}$, Raamsdonk $\mathrm{L}$. Contribution of the individual $\mathrm{HXT}$ gene products to $\mathrm{CO}_{2}$ production. Folia Microbiol. 1998;43:197-200.

Knijnenburg TA, de Winde JH, Daran JM, Daran-Lapujade P, Pronk JT, Reinders MJT, et al. Exploiting combinatorial cultivation conditions to infer transcriptional regulation. BMC Genomics. 2007;8:25-39.

Kresnowati MTAP, van Winden WA, Almering MJH, ten Pierick A, Ras C, Knijnenburg TA, et al. When transcriptome meets metabolome: fast cellular responses of yeast to sudden relief of glucose limitation. Mol Syst Biol. 2006; 2:49-65.

Kuthan M, Devaux F, Janderova B, Slaninova I, Jacq C, Palkova Z. Domestication of wild Saccharomyces cerevisiae is accompanied by changes in gene expression and colony morphology. Mol Microbiol. 2003;47:745-54.

Kuyper M, Harhangi HR, Stave AK, Winkler AA, Jetten MSM, de Laat WTAM, et al. High-level functional expression of a fungal xylose isomerase: the key to efficient ethanolic fermentation of xylose by Saccharomyces cerevisiae? FEMS Yeast Res. 2003;4:69-78.

Kuyper M, Hartog MMP, Toirkens MJ, Almering MJH, Winkler AA, van Dijken JP, et al. Metabolic engineering of a xylose-isomerase-expressing Saccharomyces cerevisiae strain for rapid anaerobic xylose fermentation. FEMS Yeast Res. 2005a;5:399-409.

Kuyper M, Toirkens MJ, Diderich JA, Winkler AA, van Dijken JP, Pronk JT. Evolutionary engineering of mixed-sugar utilization by a xylose-fermenting Saccharomyces cerevisiae strain. FEMS Yeast Res. 2005b;5:925-34.

Kuyper M, Winkler AA, van Dijken JP, Pronk JT. Minimal metabolic engineering of Saccharomyces cerevisiae for efficient anaerobic xylose fermentation: a proof of principle. FEMS Yeast Res. 2004;4:655-64.

Lagunas R. Sugar transport in Saccharomyces cerevisiae. FEMS Microbiol Rev. 1993;104:22942.

Lucero $\mathrm{P}$, Lagunas R. Catabolite inactivation of the yeast maltose transporter requires ubiquitin-ligase NPI1/RSP5 and ubiquitin-hydrolase NPI2/DOA4. FEMS Microbiol Lett. 1997;147:273-7. 
Lutfiyya LL, Johnston M. Two zinc-finger-containing repressors are responsible for glucose repression of SUC2 expression. Mol Cell Biol. 1996;16:4790-7.

Luttik MAH, Kotter P, Salomons FA, van der Klei IJ, van Dijken JP, Pronk JT. The Saccharomyces cerevisiae ICL2 gene encodes a mitochondrial 2-methylisocitrate lyase involved in propionyl-coenzyme A metabolism. J Bacteriol. 2000;182:7007-13.

Macedo ID. Greenhouse gas emissions and energy balances in bio-ethanol production and utilization in Brazil (1996). Biomass \& Bioenergy. 1998;14:77-81.

Medintz I, Jiang H, Han EK, Cui W, Michels CA. Characterization of the glucose-induced inactivation of maltose permease in Saccharomyces cerevisiae. J Bacteriol. 1996;178:224554.

Ministério da Agricultura, Pecuária e Abastecimento. Anuário estatístico da agroenergia $2010 . \quad$ Avaiable from: http://www.agricultura.gov.br/arq_editor/file/Desenvolvimento_Sustentavel/Agroenergia/a nuario_agroenergia/index.html [2011 Apr 19].

Mwesigye PK, Barford JP. Transport of sucrose by Saccharomyces cerevisiae. J Ferment Bioeng. 1994;77:687-90.

Mwesigye PK, Barford JP. Mechanism of sucrose utilisation by Saccharomyces cerevisiae. J Gen Appl Microbiol. 1996;42:297-306.

Naumov GI, Naumova ES, Michels CA. Genetic variation of the repeated MAL loci in natural populations of Saccharomyces cerevisiae and Saccharomyces paradoxus. Genetics. 1994;136:803-12.

Needleman R. Control of maltase synthesis in yeast. Mol Microbiol. 1991;5:2079-84.

Nehlin JO, Ronne H. Yeast Mig1 Repressor is related to the mammalian early growthresponse and wilms-tumor finger proteins. EMBO J. 1990;9:2891-8. 
Nelissen B, DeWachter R, Goffeau A. Classification of all putative permeases and other membrane plurispanners of the major facilitator superfamily encoded by the complete genome of Saccharomyces cerevisiae. FEMS Microbiol Rev. 1997;21:113-34.

Nelissen B, Mordant P, Jonniaux JL, DeWachter R, Goffeau A. Phylogenetic classification of the major superfamily of membrane transport facilitators, as deduced from yeast genome sequencing. FEBS Lett. 1995;377:232-6.

$\mathrm{Ni} \mathrm{B}$, Needleman RB. Identification of the upstream activating sequence of $M A L$ and the binding-sites for the MAL63 activator of Saccharomyces cerevisiae. Mol Cell Biol. 1990;10:3797-800.

Nissen TL, Kielland-Brandt MC, Nielsen J, Villadsen J. Optimization of ethanol production in Saccharomyces cerevisiae by metabolic engineering of the ammonium assimilation. Metab Eng. 2000;2:69-77.

Olsson L, Nielsen J. On-line and in situ monitoring of biomass in submerged cultivations. Trends Biotechnol. 1997;15:517-22.

Orlowski JH, Barford JP. Direct uptake of sucrose by Saccharomyces cerevisiae in batch and continuous culture. J Gen Appl Microbiol. 1991;37:215-8.

Ostergaard S, Olsson L, Johnston M, Nielsen J. Increasing galactose consumption by Saccharomyces cerevisiae through metabolic engineering of the GAL gene regulatory network. Nat Biotechnol. 2000;18:1283-6.

Ozcan S, Johnston M. Function and regulation of yeast hexose transporters. Microbiol Mol Biol Rev. 1999;63:554-69.

Ozcan S, Vallier LG, Flick JS, Carlson M, Johnston M. Expression of the SUC2 gene of Saccharomyces cerevisiae is induced by low levels of glucose. Yeast. 1997;13:127-37.

Pantazopoulou A, Diallinas G. Fungal nucleobase transporters. FEMS Microbiol Rev. 2007;31:657-75.

Piper MDW, Daran-Lapujade P, Bro C, Regenberg B, Knudsen S, Nielsen J, et al. Reproducibility of oligonucleotide microarray transcriptome analyses - An interlaboratory 
comparison using chemostat cultures of Saccharomyces cerevisiae. J Biol Chem. 2002;277:37001-8.

Postma E, Verduyn C, Scheffers WA, Vandijken JP. Enzymic analysis of the crabtree effect in glucose-limited chemostat cultures of Saccharomyces cerevisiae. Appl Environ Microbiol. 1989;55:468-77.

Pronk JT. Auxotrophic yeast strains in fundamental and applied research. Appl Environ Microbiol. 2002;68:2095-100.

Renewable Fuels Association. Ethanol industry statistics 2010. Available from: http://www.ethanolrfa.org/pages/statistics. [2011 Apr 04].

Riballo E, Herweijer M, Wolf DH, Lagunas R. Catabolite inactivation of the yeast maltose transporter occurs in the vacuole after internalization by endocytosis. J Bacteriol. 1995;177:5622-7.

Roberts IN, Oliver SG. The yin and yang of yeast: biodiversity research and systems biology as complementary forces driving innovation in biotechnology. Biotechnol Lett. 2011;33:477-87.

Rose $M$, Winston $F$. identification of a ty insertion within the coding sequence of the scerevisiae URA3 gene. Molec Gen Genet. 1984;193:557-60.

Santos E, Rodriguez L, Elorza MV, Sentandreu R. Uptake of sucrose by Saccharomyces cerevisiae. Arch Biochem Biophys. 1982;216:652-60.

Sauer U. Evolutionary engineering of industrially important microbial phenotypes. Adv Biochem Eng Biotechnol. 2001;73:129-69.

Schimidell W, Lima UA, Aquarone E, Borzani W. Biotecnologia Industrial: Engenharia Bioquímica. São Paulo: Edgard Blücher; 2001. v. 2. 541 p.

Serrano R. Energy-requirements for maltose transport in yeast. Eur J Biochem. 1977;80:97102. 
Serrano R, Kiellandbrandt MC, Fink GR. Yeast plasma-membrane ATPase is essential for growth and has homology with $\left(\mathrm{Na}^{+}\right.$and $\left.\mathrm{K}^{+}\right), \mathrm{K}^{+}$- and $\mathrm{Ca}^{2}{ }^{2+}$-Atpases. Nature. 1986;319:689-93.

Sherman F. Getting started with yeast. Methods Enzymol. 1991;194:3-21.

Sikorski RS, Hieter P. A system of shuttle vectors and yeast host strains designed for efficient manipulation of dna in Saccharomyces cerevisiae. Genetics. 1989;122:19-27.

Silveira MCF, Carvajal E, Bon EPS. Assay for in vivo yeast invertase activity using NaF. Anal Biochem. 1996;238:26-8.

Silverman M. Structure and function of hexose transporters. Annu Rev Biochem. 1991;60:757-94.

Sjodin A, Svensson K, Lindgren M, Forsman M, Larsson P. Whole-genome sequencing reveals distinct mutational patterns in closely related laboratory and naturally propagated Francisella tularensis strains. PLoS One. 2010; 5:e11556.

Sonderegger M, Sauer U. Evolutionary engineering of Saccharomyces cerevisiae for anaerobic growth on xylose. Appl Environ Microbiol. 2003;69:1990-8.

Stambuk BU. A simple experiment illustrating metabolic regulation: induction versus repression of yeast alpha-glucosidase. Biochemical Education. 1999;27:177-80.

Stambuk BU, Araújo PS, Basso LC, Amorim HV, Trichez D, Alves-Jr SL, Klinkowstrom AM, Miletti LC, Machado LO, Badotti F, Espirito-Santo JCA, SchlogI PS, Dário MG. Processo para modificar geneticamente leveduras Saccharomyces, e seu uso em processos fermentativos de produção de metabólitos. INPI PI 0901254-0. 2009.

Stambuk BU, Batista AS, De Araujo PS. Kinetics of active sucrose transport in Saccharomyces cerevisiae. J Biosci Bioeng. 2000;89:212-4.

Stambuk BU, de Araujo PS. Kinetics of active alpha-glucoside transport in Saccharomyces cerevisiae. FEMS Yeast Res. 2001;1:73-8. 
Stambuk BU, Panek AD, Crowe JH, Crowe LM, de Araujo PS. Expression of high-affinity trehalose- $\mathrm{H}^{+}$symport in Saccharomyces cerevisiae. Biochimica Et Biophysica Acta-General Subjects. 1998;1379:118-28.

Stephanopoulos G. Metabolic engineering. Biotechnol Bioeng. 1998;58:119-20.

Teste MA, Francois JM, Parrou JL. Characterization of a new multigene family encoding isomaltases in the yeast Saccharomyces cerevisiae, the IMA family. J Biol Chem.285:2681524.

Tilman D, Hill J, Nelson E, Polasky S, Tiffany D. Environmental, economic, and energetic costs and benefits of biodiesel and ethanol biofuels. Proc Natl Acad Sci USA. 2006;103:11206-10.

van Dijken JP, Bauer J, Brambilla L, Duboc P, Francois JM, Gancedo C, et al. An interlaboratory comparison of physiological and genetic properties of four Saccharomyces cerevisiae strains. Enzyme Microb Technol. 2000;26:706-14.

Vanoni M, Sollitti P, Goldenthal M, Marmur J. Structure and regulation of the multigene family controlling maltose fermentation in budding yeast. Prog Nucleic Acid Res Mol Biol. 1989;37:281-322.

Verduyn C, Postma E, Scheffers WA, Vandijken JP. Energetics of Saccharomyces cerevisiae in anaerobic glucose-limited chemostat cultures. Journal of General Microbiology. 1990;136:405-12.

Verduyn C, Postma E, Scheffers WA, Vandijken JP. Physiology of Saccharomyces cerevisiae in anaerobic glucose-limited chemostat cultures. Journal of General Microbiology. 1990;136:395-403.

Verduyn C, Postma E, Scheffers WA, Vandijken JP. Effect of benzoic-acid on metabolic fluxes in yeasts - a continuous-culture study on the regulation of respiration and alcoholic fermentation. Yeast. 1992;8:501-17.

Verstrepen KJ, Iserentant D, Malcorps P, Derdelinckx G, Van Dijck P, Winderickx J, et al. Glucose and sucrose: hazardous fast-food for industrial yeast? Trends Biotechnol. 2004;22:531-7. 
Weusthuis RA, Adams H, Scheffers WA, Vandijken JP. Energetics and kinetics of maltose transport in Saccharomyces cerevisiae - a continuous-culture study. Appl Environ Microbiol. 1993;59:3102-9.

Wick LM, Weilenmann H, Egli T. The apparent clock-like evolution of Escherichia coli in glucose-limited chemostats is reproducible at large but not at small population sizes and can be explained with Monod kinetics. Microbiology. 2002;148:2889-902.

Wisselink HW, Toirkens MJ, Berriel MDF, Winkler AA, van Dijken JP, Pronk JT, et al. Engineering of Saccharomyces cerevisiae for efficient anaerobic alcoholic fermentation of Larabinose. Appl Environ Microbiol. 2007;73:4881-91.

Wisselink HW, Toirkens MJ, Wu Q, Pronk JT, van Maris AJA. Novel evolutionary engineering approach for accelerated utilization of glucose, xylose, and arabinose mixtures by engineered Saccharomyces cerevisiae strains. Appl Environ Microbiol. 2009;75:907-14.

Wyman CE, Hinman ND. Ethanol - fundamentals of production from renewable feedstocks and use as a transportation fuel. Appl Biochem Biotechnol. 1990;24-5:735-53.

Zastrow CR, Hollatz C, de Araujo PS, Stambuk BU. Maltotriose fermentation by Saccharomyces cerevisiae. J Ind Microbiol Biotechnol. 2001;27:34-8.

Zelle RM, Harrison JC, Pronk JT, van Maris AJA. Anaplerotic role for cytosolic malic enzyme in engineered Saccharomyces cerevisiae strains. Appl Environ Microbiol. 2011;77:732-8. 


\section{ANEXO A - Lista dos genes com expressão aumentada na linhagem iSUC2 evoluída em relação à iSUC2 parental}

Quadro 1: Lista dos 122 genes com expressão aumentada na linhagem iSUC2 evoluída em relação à iSUC2 parental, durante o estado-estacionário de quimiostatos anaeróbicos limitados por sacarose

(continua).

\begin{tabular}{|c|c|c|c|c|c|}
\hline Gene & Descrição do gene & iSUC2 & iSUC2 evoluída & $\begin{array}{l}\text { Aumento da } \\
\text { expressão }\end{array}$ & q-value \\
\hline $\begin{array}{l}\text { (Nome } \\
\text { padrão) }\end{array}$ & $\begin{array}{l}\text { (Nome sistemático com breve descrição obtida da } \\
\text { base de dados SGD) }\end{array}$ & $\begin{array}{l}\text { Unidades } \\
\text { arbitrárias }\end{array}$ & $\begin{array}{l}\text { Unidades } \\
\text { arbitrárias }\end{array}$ & $\begin{array}{l}\text { (iSUC2 evoluída } \\
\text { vs. isUC2) }\end{array}$ & $(\%)$ \\
\hline HSP12 & YFL014W 12 kDa heat shock protein & 317 & 1977 & 6,2 & 0,00 \\
\hline MCD4 & YKL165C Morphogenesis Checkpoint Dependent & 247 & 923 & 3,7 & 0,00 \\
\hline \multirow[t]{4}{*}{ TSA2 } & $\begin{array}{l}\text { YDR453C strong similarity to thiol-specific antioxidant } \\
\text { proteins }\end{array}$ & 86 & 352 & 4,1 & 0,00 \\
\hline & YHR210C UDP-glucose-4-epimerase (GAL10, galE) & 226 & 3340 & 14,8 & 0,00 \\
\hline & YDR133C questionable ORF & 534 & 1429 & 2,7 & 0,00 \\
\hline & $\begin{array}{l}\text { YNL194C strong similarity to YDL222c and similarity to } \\
\text { Sur7p }\end{array}$ & 12 & 119 & 9,9 & 0,00 \\
\hline STF2 & YGR008C ATPase stabilizing factor & 511 & 1074 & 2,1 & 0,00 \\
\hline \multirow[t]{2}{*}{ CAR2 } & YLR438W ornithine aminotransferase & 195 & 566 & 2,9 & 0,00 \\
\hline & YPR015C similarity to transcription factors & 38 & 100 & 2,6 & 0,00 \\
\hline \multirow[t]{2}{*}{$T S L 1$} & $\begin{array}{l}\text { YML100W } 123 \text { kD regulatory subunit of trehalose-6- } \\
\text { phosphate synthase } \bigvee \text { phosphatase complex\; } \\
\text { homologous to TPS3 gene product }\end{array}$ & 82 & 335 & 4,1 & 0,00 \\
\hline & YGL121C hypothetical protein & 138 & 368 & 2,7 & 0,00 \\
\hline \multirow[t]{3}{*}{$S P / 1$} & $\begin{array}{l}\text { YER150W strong similarity to putative cell surface } \\
\text { glycoprotein Sed1p }\end{array}$ & 162 & 906 & 5,6 & 0,00 \\
\hline & YDL247W strong similarity to sugar transport proteins & 24 & 395 & 16,7 & 0,00 \\
\hline & $\begin{array}{l}\text { YMR090W strong similarity to B. subtilis conserved } \\
\text { hypothetical protein yhfK }\end{array}$ & 28 & 108 & 3,9 & 0,00 \\
\hline$M A L 11$ & YGR289C alpha-glucoside transporter & 861 & 3369 & 3,9 & 0,00 \\
\hline \multirow[t]{2}{*}{$A D R 1$} & $\begin{array}{l}\text { YDR216W positive transcriptional regulator of ADH2 } \\
\text { and peroxisomal protein genes }\end{array}$ & 34 & 89 & 2,6 & 3,72 \\
\hline & $\begin{array}{l}\text { YJR124C weak similarity to Staphylococcus multidrug } \\
\text { resistance protein }\end{array}$ & 70 & 215 & 3,1 & 3,72 \\
\hline \multirow[t]{2}{*}{ DSE1 } & $\begin{array}{l}\text { YER124C weak similarity to Dictyostelium WD40 } \\
\text { repeat protein } 2\end{array}$ & 61 & 134 & 2,2 & 3,72 \\
\hline & YIL059C hypothetical protein & 23 & 739 & 32,8 & 3,72 \\
\hline \multirow[t]{2}{*}{ MSC1 } & $\begin{array}{l}\text { YML128C C-terminal part starting with aa } 262 \text { cause } \\
\text { growth inhibition when overexpressed }\end{array}$ & 65 & 274 & 4,2 & 4,64 \\
\hline & $\begin{array}{l}\text { YKL151C similarity to C.elegans hypothetical protein } \\
\text { R107.2 }\end{array}$ & 108 & 259 & 2,4 & 4,64 \\
\hline \multirow[t]{2}{*}{ HSP26 } & YBR072W heat shock protein 26 & 107 & 563 & 5,3 & 4,64 \\
\hline & YMR107W hypothetical protein & 19 & 176 & 9,1 & 4,64 \\
\hline \multirow[t]{2}{*}{ CLB1 } & YGR108W G(sub)2-specific B-type cyclin & 12 & 119 & 9,9 & 4,64 \\
\hline & $\begin{array}{l}\text { YNL115C weak similarity to S.pombe hypothetical } \\
\text { protein SPAC23C11 }\end{array}$ & 28 & 75 & 2,7 & 4,64 \\
\hline GRE3 & YHR104W Aldo-keto reductase & 134 & 364 & 2,7 & 4,64 \\
\hline \multirow[t]{2}{*}{ CYB2 } & $\begin{array}{l}\text { YML054C Cytochrome b2 [L--lactate cytochrome-c } \\
\text { oxidoreductase] }\end{array}$ & 48 & 151 & 3,2 & 4,64 \\
\hline & YOL053C-A DNA Damage Responsive & 280 & 847 & 3,0 & 4,64 \\
\hline$D D R 48$ & $\begin{array}{l}\text { YMR173W flocculent specific protein \; contains }>35 \\
\text { repeats of the amino acid sequence NNNDSYGS }\end{array}$ & 264 & 789 & 3,0 & 4,64 \\
\hline G/T1 & $\begin{array}{l}\text { YCR098C permease involved in the uptake of } \\
\text { glycerophosphoinositol (GroPIns) }\end{array}$ & 18 & 114 & 6,4 & 4,64 \\
\hline HSP3O & $\begin{array}{l}\text { YCR021C Protein induced by heat shock, ethanol } \\
\text { treatment, and entry into stationary phasel; located in } \\
\text { plasma membrane }\end{array}$ & 53 & 536 & 10,1 & 4,64 \\
\hline FSP2 & YJL221C homology to maltase(alpha-D-glucosidase) & 276 & 1736 & 6,3 & 4,64 \\
\hline HBT1 & YDL223C weak similarity to mucin & 44 & 95 & 2,2 & 4,64 \\
\hline GRE2 & YOL151W induced by osmotic stress $\backslash ;$ similar to & 12 & 64 & 5,3 & 4,64 \\
\hline
\end{tabular}


(continuação)

\begin{tabular}{|c|c|c|c|c|c|}
\hline & dihydroflavonol 4-reductase from plants & & & & \\
\hline TPS1 & $\begin{array}{l}\text { YBR126C } 56 \text { kD synthase subunit of trehalose-6- } \\
\text { phosphate synthase } \bigvee \text { phosphatase complex }\end{array}$ & 339 & 725 & 2,1 & 4,64 \\
\hline REG2 & $\begin{array}{l}\text { YBR050C Possible regulatory subunit for the PP1 } \\
\text { family protein phosphatase Glc7p }\end{array}$ & 172 & 682 & 4,0 & 4,64 \\
\hline RPS22B & YLR367W Ribosomal protein S22B (S24B) (rp50) (YS22) & 182 & 640 & 2,1 & 4,64 \\
\hline FOX2 & $\begin{array}{l}\text { YKR009C peroxisomal multifunctional beta-oxidation } \\
\text { protein }\end{array}$ & 39 & 139 & 3,6 & 4,64 \\
\hline \multirow[t]{2}{*}{ NCE102 } & $\begin{array}{l}\text { YPR149W involved in secretion of proteins that lack } \\
\text { classical secretory signal sequences }\end{array}$ & 474 & 1147 & 2,4 & 4,64 \\
\hline & YOR173W strong similarity to YLR270w & 63 & 326 & 5,2 & 4,64 \\
\hline ALD3 & YMR169C Aldehyde Dehydrogenase (NAD(P)+) & 57 & 146 & 2,6 & 4,64 \\
\hline PTK1 & $\begin{array}{l}\text { YKL198C probable serine } \bigvee \text { threonine-specific protein } \\
\text { kinase (EC 2.7.1.-) }\end{array}$ & 16 & 219 & 13,9 & 4,64 \\
\hline \multirow[t]{2}{*}{ MBR1 } & YKL093W MBR1 protein precursor & 12 & 74 & 6,2 & 4,64 \\
\hline & $\begin{array}{l}\text { YCL026C-A Protein involved in the integration of lipid } \\
\text { signaling pathways with cellular homeostatis }\end{array}$ & 41 & 180 & 4,4 & 4,64 \\
\hline DOG2 & YHR043C 2-deoxyglucose-6-phosphate phosphatase & 294 & 689 & 2,3 & 4,64 \\
\hline TOS8 & $\begin{array}{l}\text { YGL096W similarity to copper homeostasis protein } \\
\text { Cup9p }\end{array}$ & 36 & 126 & 3,5 & 4,64 \\
\hline PHO84 & $\begin{array}{l}\text { YML123C inorganic phosphate transporter, } \\
\text { transmembrane protein }\end{array}$ & 26 & 228 & 8,8 & 4,64 \\
\hline UGA2 & $\begin{array}{l}\text { YBR006W Probable aldehyde dehydrogenase (EC } \\
\text { 1.2.1.-) }\end{array}$ & 35 & 195 & 5,6 & 4,64 \\
\hline SOL1 & YNR034w-a hypothetical protein & 345 & 1013 & 2,9 & 4,64 \\
\hline \multirow[t]{2}{*}{ SPO73 } & YER046W hypothetical protein & 48 & 99 & 2,0 & 4,64 \\
\hline & $\begin{array}{l}\text { YJL218W strong similarity to E.coli galactoside O- } \\
\text { acetyltransferase }\end{array}$ & 65 & 1380 & 21,1 & 4,64 \\
\hline \multirow[t]{2}{*}{ SSE2 } & $\begin{array}{l}\text { YBR169C HSP70 family member, highly homologous to } \\
\text { Sse1p }\end{array}$ & 124 & 322 & 2,6 & 4,64 \\
\hline & $\begin{array}{l}\text { YDL193W similarity to N.crassa hypothetical } 32 \mathrm{kDa} \\
\text { protein }\end{array}$ & 40 & 87 & 2,2 & 4,64 \\
\hline TFS1 & YLR178C suppressor of cdc25 & 174 & 638 & 3,7 & 4,64 \\
\hline ECM30 & YLR436C ExtraCellular Mutant & 40 & 107 & 2,7 & 4,64 \\
\hline MAL32 & YBR299W Maltase (EC 3.2.1.20) & 1472 & 3806 & 2,6 & 4,64 \\
\hline MIG2 & $\begin{array}{l}\text { YGL209W Protein containing zinc fingers very similar } \\
\text { to zinc fingers in Mig1p }\end{array}$ & 12 & 69 & 5,7 & 4,64 \\
\hline SOL4 & YGR248W similar to SOL3 & 26 & 163 & 6,2 & 4,64 \\
\hline \multirow[t]{3}{*}{$B \cup D 9$} & $\begin{array}{l}\text { YGR041W Among a group of genes whose products } \\
\text { are necessary for bud-site selection\; likely } \\
\text { involvement in positioning the proximal pole signal }\end{array}$ & 74 & 151 & 2,0 & 4,64 \\
\hline & YER158C weak similarity to Afr1p & 67 & 169 & 2,5 & 4,64 \\
\hline & YPR013C similarity to transcription factors & 65 & 189 & 2,9 & 4,64 \\
\hline MNN4 & YKL201C regulates the mannosylphosphorylation & 44 & 129 & 3,0 & 4,64 \\
\hline \multirow[t]{2}{*}{ SIP18 } & YMR175W protein of unknown function & 12 & 36 & 3,0 & 4,64 \\
\hline & YJR160C strong similarity to Mal31p & 25 & 428 & 17,4 & 4,64 \\
\hline PDE1 & $\begin{array}{l}\text { YGL248W } 3,5 \text {-Cyclic-nucleotide phosphodiesterase, } \\
\text { low affinity }\end{array}$ & 71 & 174 & 2,5 & 4,64 \\
\hline \multirow[t]{2}{*}{ YPS5 } & YGL259W GPI-anchored aspartic protease & 36 & 73 & 2,0 & 4,64 \\
\hline & YIL056W similarity to YER064c & 75 & 229 & 3,1 & 4,64 \\
\hline HSP104 & YLL026W heat shock protein 104 & 199 & 511 & 2,6 & 4,64 \\
\hline \multirow[t]{2}{*}{ PEX21 } & $\begin{array}{l}\text { YGR239C weak similarity to hypothetical protein } \\
\text { YHR160c }\end{array}$ & 45 & 139 & 3,1 & 4,64 \\
\hline & YLL023C similarity to hypothetical protein YLR064w & 107 & 232 & 2,2 & 4,64 \\
\hline \multirow[t]{2}{*}{$M A L 31$} & YBR298C maltose permease & 218 & 1445 & 6,6 & 4,64 \\
\hline & YJL217W hypothetical protein & 534 & 2865 & 5,4 & 4,64 \\
\hline CMK2 & YOL016C Calmodulin-dependent protein kinase & 63 & 189 & 3,0 & 4,64 \\
\hline \multirow[t]{3}{*}{ YRO2 } & $\begin{array}{l}\text { YBR054W Homolog to HSP30 heat shock protein YRO1 } \\
\text { (S. cerevisiae) } 7\end{array}$ & 25 & 1058 & 42,2 & 4,64 \\
\hline & YJR115W similarity to hypothetical protein YBL043w & 26 & 133 & 5,2 & 4,64 \\
\hline & YAL061W similarity to alcohol/sorbitol dehydrogenase & 12 & 38 & 3,2 & 4,64 \\
\hline RSE1 & YML049C RNA splicing and ER to Golgi transport & 59 & 122 & 2,1 & 4,64 \\
\hline ARO3 & $\begin{array}{l}\text { YDR035W DAHP synthase \; a.k.a. phospho-2-dehydro- } \\
\text { 3-deoxyheptonate aldolase, phenylalanine-inhibited } \backslash \\
\text { phospho-2-keto-3-deoxyheptonate aldolase } \backslash ; 2- \\
\text { dehydro-3-deoxyphosphoheptonate aldolase } \backslash ; \text { - } \\
\text { deoxy-D-arabine-heptulosonate-7-phosphate synthase }\end{array}$ & 88 & 194 & 2,2 & 4,64 \\
\hline INO1 & YJL153C L-myo-inositol-1-phosphate synthase & 74 & 535 & 7,2 & 4,64 \\
\hline YAT1 & YAR035W Outer carnitine acetyltransferase, & 74 & 296 & 4,0 & 4,64 \\
\hline
\end{tabular}


(conclusão)

\begin{tabular}{|c|c|c|c|c|c|}
\hline & mitochondrial & & & & \\
\hline \multirow[t]{2}{*}{ RPS22B } & YLR367W Ribosomal protein S22B (S24B) (rp50) (YS22) & 182 & 640 & 3,5 & 4,64 \\
\hline & $\begin{array}{l}\text { YJL021C weak similarity to S.pombe hypothetical } \\
\text { protein SPAC23A1.16 }\end{array}$ & 51 & 123 & 2,4 & 4,64 \\
\hline DSE3 & YOR264W hypothetical protein & 62 & 131 & 2,1 & 4,64 \\
\hline \multirow[t]{3}{*}{ HST2 } & YPL015C Homolog of SIR2 & 58 & 124 & 2,1 & 4,64 \\
\hline & YER079W hypothetical protein & 43 & 101 & 2,3 & 4,64 \\
\hline & YPL047W hypothetical protein & 83 & 187 & 2,2 & 4,64 \\
\hline \multirow[t]{2}{*}{$D D R 48$} & YMR173W-A questionable ORF & 1058 & 2221 & 2,1 & 4,64 \\
\hline & YNL253W hypothetical protein & 19 & 42 & 2,2 & 4,64 \\
\hline \multirow{2}{*}{ HXT2 } & YMR011W high affinity hexose transporter-2 & 184 & 434 & 2,4 & 4,64 \\
\hline & YLL055W similarity to Dal5p & 41 & 98 & 2,4 & 4,64 \\
\hline \multirow[t]{4}{*}{ DSE2 } & YHR143W Ser-Thr rich protein & 894 & 1936 & 2,2 & 4,64 \\
\hline & YJL216C strong similarity to Mal62p & 12 & 331 & 27,5 & 4,64 \\
\hline & YMR291W similarity to ser/thr protein kinase & 88 & 186 & 2,1 & 4,64 \\
\hline & YOR062C strong similarity to YKR075c & 24 & 249 & 10,3 & 4,64 \\
\hline RPS22B & YLR367W Ribosomal protein S22B (S24B) (rp50) (YS22) & 182 & 640 & 2,3 & 4,64 \\
\hline EPT1 & $\begin{array}{l}\text { YHR123W sn-1,2-diacylglycerol ethanolamine- and } \\
\text { cholinephosphotranferase }\end{array}$ & 134 & 346 & 2,6 & 4,64 \\
\hline CTA1 & YDR256C catalase A & 12 & 38 & 3,2 & 4,64 \\
\hline \multirow[t]{2}{*}{$E C / 1$} & YLR284C Peroxisomal enoyl-CoA hydratase & 28 & 63 & 2,2 & 4,64 \\
\hline & YHR033W Pro1p (Gamma-glutamyl kinase) & 68 & 410 & 6,0 & 4,64 \\
\hline GLC3 & YEL011W 1,4-glucan-6-(1,4-glucano)-transferase & 314 & 867 & 2,8 & 4,64 \\
\hline HXT12 & YIL171W High-affinity hexose transporter & 27 & 107 & 4,1 & 4,64 \\
\hline$N P L 3$ & $\begin{array}{l}\text { YDR432W nuclear shuttling protein with an RNA } \\
\text { recognition motif }\end{array}$ & 21 & 81 & 3,9 & 4,64 \\
\hline \multirow[t]{3}{*}{ NCA3 } & $\begin{array}{l}\text { YJL116C With NCA2, regulates proper expression of } \\
\text { subunits } 6 \text { (Atp6p) and } 8 \text { (Atp8p ) of the Fo-F1 ATP } \\
\text { synthase }\end{array}$ & 40 & 106 & 2,7 & 4,64 \\
\hline & YLR364W hypothetical protein & 48 & 104 & 2,2 & 4,64 \\
\hline & YNL195C hypothetical protein & 17 & 69 & 4,1 & 4,64 \\
\hline AHP1 & $\begin{array}{l}\text { YLR109W similarity to C.boidinii peroxisomal } \\
\text { membrane protein 20K A }\end{array}$ & 381 & 1018 & 2,7 & 4,64 \\
\hline GIP2 & $\begin{array}{l}\text { YER054C Glc7-interacting protein\; shares homology } \\
\text { with PIG2\; contains conserved } 25 \text { residue motif, } \\
\text { called the GVNK motif, also found in GAC1, PIG1, PIG2, } \\
\text { and RGI, the mammalian type } 1 \text { phosphatase targeting } \\
\text { subunit. }\end{array}$ & 17 & 58 & 3,5 & 4,64 \\
\hline \multirow[t]{2}{*}{ GGA1 } & $\begin{array}{l}\text { YDR358W strong similarity to hypothetical protein } \\
\text { YHR108w and weak similarity to signal transducing } \\
\text { adaptor from mouse and man }\end{array}$ & 91 & 203 & 2,2 & 4,64 \\
\hline & YBL029W hypothetical protein & 93 & 249 & 2,7 & 4,64 \\
\hline STD1 & $\begin{array}{l}\text { YOR047C homologous to MTH1\; interacts with the } \\
\text { SNF1 protein kinase and TBP in two-hybrid and in in } \\
\text { vitro binding studies }\end{array}$ & 27 & 133 & 4,9 & 4,64 \\
\hline GDB1 & $\begin{array}{l}\text { YPR184W similarity to human 4-alpha- } \\
\text { glucanotransferase (EC 2.4.1.25)/amylo-1,6- } \\
\text { glucosidase (EC 3.2.1.33) }\end{array}$ & 229 & 623 & 2,7 & 4,64 \\
\hline BTN2 & YGR142W similarity to hypothetical protein YPR158w & 99 & 219 & 2,2 & 4,64 \\
\hline \multirow[t]{2}{*}{ MAL13 } & YGR288W maltose pathway regulatory protein & 49 & 513 & 10,5 & 4,64 \\
\hline & YNR009W hypothetical protein & 41 & 96 & 2,3 & 4,64 \\
\hline$S S A 3$ & $\begin{array}{l}\text { YBL075C heat-inducible cytosolic member of the } 70 \\
\text { kDa heat shock protein family }\end{array}$ & 36 & 92 & 2,5 & 4,64 \\
\hline CBF2 & $\begin{array}{l}\text { YGR140W } 110 \mathrm{kDa} \text { subunit of the centromere binding } \\
\text { factor CBF3 }\end{array}$ & 45 & 93 & 2,1 & 4,64 \\
\hline \multirow[t]{2}{*}{ VRP1 } & YLR337C Proline-rich protein verprolin & 103 & 217 & 2,1 & 4,64 \\
\hline & YLR046C strong similarity to Rta1p and Rtm1p protein & 12 & 33 & 2,7 & 4,64 \\
\hline \multirow[t]{2}{*}{ YGP1 } & $\begin{array}{l}\text { YNL160W YGP1 encodes gp37, a glycoprotein } \\
\text { synthesized in response to nutrient limitation which is } \\
\text { homologous to the sporulation-specific SPS100 gene }\end{array}$ & 74 & 612 & 8,3 & 4,64 \\
\hline & YDR034W-B identified by SAGE expression analysis & 77 & 180 & 2,3 & 4,64 \\
\hline \multirow[t]{2}{*}{ GPH1 } & YPR160W Glycogen phosphorylase & 196 & 492 & 2,5 & 4,64 \\
\hline & YDR070C hypothetical protein & 21 & 132 & 6,2 & 4,64 \\
\hline
\end{tabular}

